\title{
COMPOUNDING FIRE DISTURBANCE HISTORY ENCOURAGES COAST \\ REDWOOD (SEQUOIA SEMPERVIRENS) REGENERATION AND \\ COMMUNITY DOMINANCE
}

\author{
A Thesis \\ presented to \\ the Faculty of California Polytechnic State University, \\ San Luis Obispo
}

\author{
In Partial Fulfillment \\ of the Requirements for the Degree \\ Master of Science in Forestry Sciences
}

by

Matthew R. Brousil

December 2016 
(C) 2016

Matthew R. Brousil

ALL RIGHTS RESERVED 
TITLE: Compounding Fire Disturbance History Encourages Coast Redwood (Sequoia sempervirens)

Regeneration and Community Dominance

AUTHOR: Matthew R. Brousil

DATE SUBMITTED: December 2016

COMMITTEE CHAIR: Sarah Bisbing, Ph.D.

Assistant Professor of Forest Ecology \& Silviculture

COMMITTEE MEMBER: Seth Davis, Ph.D.

Assistant Professor, Forest and Rangeland

Stewardship, Colorado State University

COMMITTEE MEMBER: Chip Appel, Ph.D.

Professor of Environmental Soil Chemistry 


\begin{abstract}
Compounding Fire Disturbance History Encourages Coast Redwood (Sequoia sempervirens) Regeneration and Community Dominance

Matthew R. Brousil
\end{abstract}

Disturbance is fundamental to forest ecosystem function and overall health, but climate change is likely to increase both disturbance frequency and intensity in the future. Forests subject to increasingly frequent and intense disturbances are more likely to experience compounding disturbance effects. Compounding disturbances may exert unpredicted, non-additive stresses on ecosystems, leading to novel conditions that may exceed the capacity for local species to survive and regenerate. I further hypothesize that compounding disturbances could create conditions misaligned with species’ adaptations by altering physical and chemical growing conditions in forest soils, affecting forest composition, structure, and, subsequently, function for many years following disturbance. A better understanding of these remnant effects will be essential to managing and conserving coast redwood forests, which are projected to see increased frequency of fire under future climate scenarios. My objectives in this study were to quantify the effects of time-since-fire and single vs. compounding disturbances on coast redwood forest structure, composition, and regeneration dynamics and to evaluate the effects of abiotic soil qualities on post-fire regeneration. I mapped and sampled coast redwood forests burned in 1985, both 1985 and 1999, 2008, and 2013; modeled regeneration as a function of burn history, understory light, and post-fire nutrient levels; and tested redwood seed regeneration in post-fire soils in a greenhouse experiment. Forest structure, composition, and regeneration following compounding disturbance were most similar to the 
homogenous, redwood-dominated forest of the recent 2013 burn. There were no unique effects of compounding disturbance on soil nutrient levels, although variations in nutrient levels generally followed patterns seen in previous studies. Soil nitrate was positively associated with coast redwood regeneration levels, showing that soil nutrients may be influential in regeneration processes following disturbance. Time since burn and single burn histories were negatively associated with regeneration levels in the field, and there were no differences in seed germination in the greenhouse between soils from different fire histories. Increases in coast redwood forest dominance accompanied declines in bay laurel and tanoak presence, indicating a shift in post-fire forest structure and composition resulting from compounding disturbance. These results illustrate a complex relationship between regeneration dynamics, post-fire soil quality, and disturbance histories. Forest homogenization from compounding disturbances may have negative implications for ecosystem services and overall function if compounding disturbances are more frequent as predicted under future climate conditions.

Keywords: coast redwood, Sequoia sempervirens, tanoak, compounding disturbance, fire, disturbance return interval, climate change, disturbance interactions 


\section{ACKNOWLEDGMENTS}

I would like to thank my funders: the USDA McIntire-Stennis Cooperative Forestry Program; the California Agricultural Research Institute; the Cal Poly College of Agriculture, Food, \& Environmental Sciences; and Save the Redwoods League. I am grateful to Dr. Seth Davis, Dr. Chip Appel, Kevin Hurt, Matt Terzes, Kara Neal, and the volunteers from the Bisbing Forest Ecology and Silviculture Lab for their help in reviewing my work and assisting with fieldwork and research support. I would like to thank Dr. Mark Readdie from UCSC Big Creek Reserve for providing insight and resources for my work at Big Creek, and Jeff Frey at Pfeiffer Big Sur State Park for assisting me with my work at Pfeiffer and helping me navigate the complications of the Soberanes Fire.

I would like to give a special thank you to Dr. Sarah Bisbing for her guidance, encouragement, and trust in taking me on as the first graduate student in her lab at Cal Poly. Thank you also to Craig Stubler, who helped ground my soil sampling ambitions in reality and ensured I thrived in my research over the last two years, and to Jeff Reimer, who made sure the Bisbing Lab and I always had what we needed to succeed. Emily, Marissa, and Tori helped me make the most of my time in SLO. Thank you all for the

great times at Luis, Spike’s, and BarrelHouse. Thank you, Rachel Olsson, for supporting me every step of the way from Washington to California and back. Finally, I thank my parents for supporting me in my academic ambitions and everywhere they have led me. 


\section{TABLE OF CONTENTS}

Page

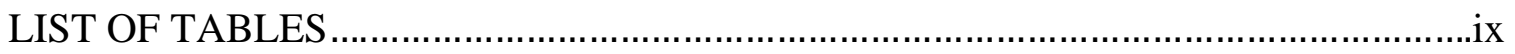

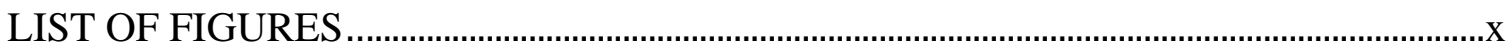

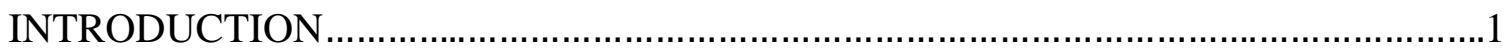

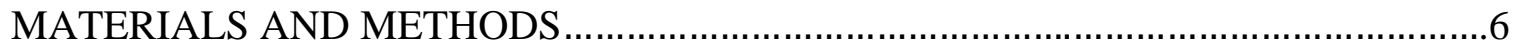

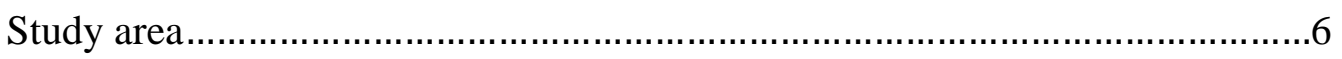

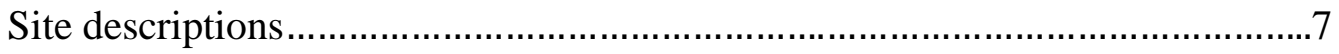

Plot selection and data collection .........................................................

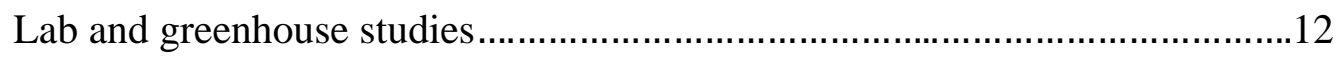

Methods of analysis ........................................................................13

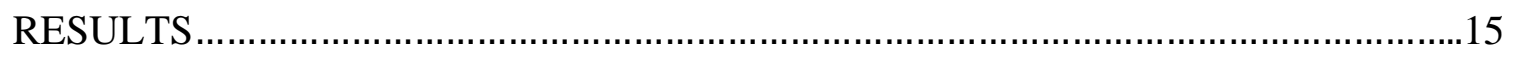

Ecological conditions........................................................................ 15

Stand structure and composition ......................................................18

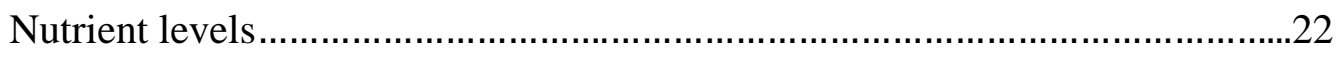

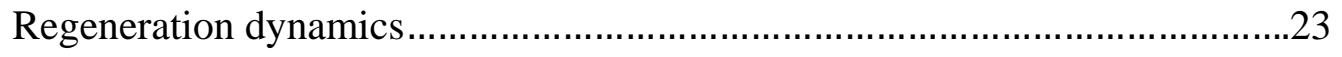

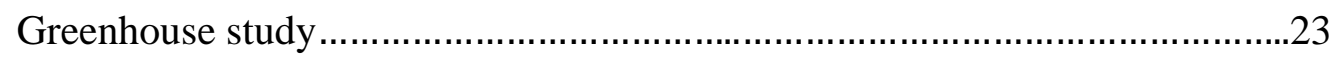

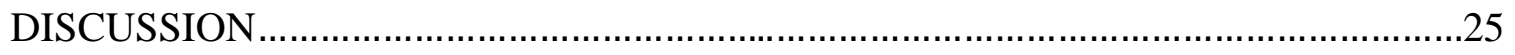

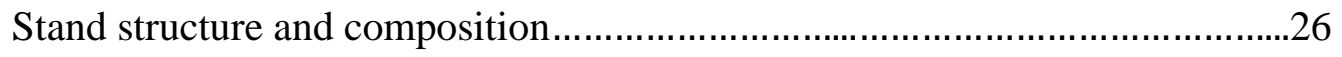

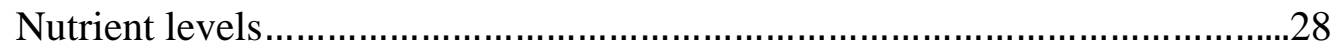

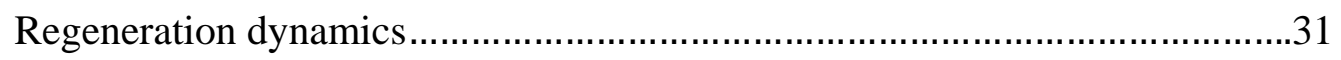


Greenhouse experiment.....................................................................34

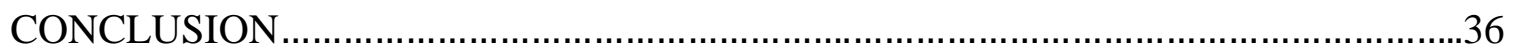

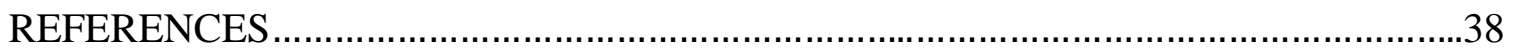

APPENDICES

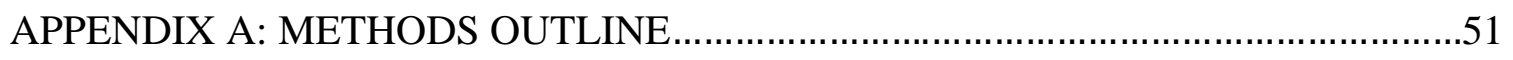

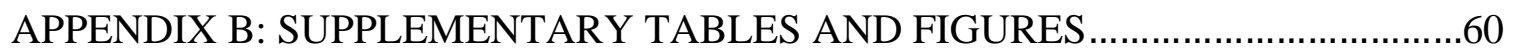




\section{LIST OF TABLES}

Table

Page

1. Description of soil type, soil series, lithology, aspect, elevation, and climate factors for the four burn histories used in this study.......

2. Site and soil properties from each sampling location within four burn histories...........17

3. Output of MRPP analysis for community composition between four burn histories, including a compounding fire history burned both in 1985 and $1999 . . . . . . . .22$

4. Fixed effect predictors of coast redwood regeneration from the final GLMM model selection

5. Number of coast redwood seeds that either germinated or did not germinate in soil from each of four burn histories

A.1. Soil classifications determined by profile description during June 2016. 


\section{LIST OF FIGURES}

Figure

1. Map of study areas in Big Sur, California............................................................

2. Distribution of overstory ( $>5 \mathrm{~cm}$ diameter at $1.37 \mathrm{~m}$ height) tree diameter size classes across four burn histories by average trees per hectare (TPH) 15

3. Species makeup for regeneration in the $0-2.5 \mathrm{~cm}$ diameter class (diameter at $1.37 \mathrm{~m}$ height) across four burn histories by average trees per hectare (TPH). 18

4. Nonmetric multidimensional scaling (NMS) ordination plots comparing (a) the community composition of mature ( $>5 \mathrm{~cm}$ diameter at $1.37 \mathrm{~m}$ height) trees and (b) the community composition of immature $(</=5 \mathrm{~cm}$ diameter at $1.37 \mathrm{~m}$ height) trees between four burn histories

5. Levels of selected soil nutrients sampled from $0-10 \mathrm{~cm}$ depth across four burn histories

A.1. Gluing redwood seeds to toothpicks.

A.2. Map of 0.25 ha research plot locations relative to fires at Big Creek Reserve properties since 1985

A.3. Map of 0.25 ha research plot locations relative to fires at Pfeiffer Big Sur State Park since 1985

A.4. Soil map units at Big Creek Reserve relative to 0.25 ha plot locations.

A.5. Soil map units at Pfeiffer Big Sur State Park Buzzard’s Roost Trail relative to 0.25 ha plot locations

A.6. Soil map units at Pfeiffer Big Sur State Park Post Creek relative to 0.25 ha plot locations. 
A.7. Front of soil pit classification sheet for Buzzard's Roost \# 1...................................64

A.8. Back of soil pit classification sheet for Buzzard's Roost \# 1....................................65

A.9. Front of soil pit classification sheet for Buzzard's Roost \# 2 2....................................66

A.10. Back of soil pit classification sheet for Buzzard’s Roost \# 2.................................67

A.11. Front of soil pit classification sheet for Post Creek \# 1..........................................68

A.12. Back of soil pit classification sheet for Post Creek \# 1.........................................69

A.13. Front of soil pit classification sheet for Post Creek \# 2..........................................70

A.14. Back of soil pit classification sheet for Post Creek \# 2.........................................71

A.15. Front of soil pit classification sheet for Whale Point \# 1 1........................................72

A.16. Back of soil pit classification sheet for Whale Point \# 1 1.........................................73

A.17. Front of soil pit classification sheet for Whale Point \# 3.........................................74

A.18. Back of soil pit classification sheet for Whale Point \# 3.........................................75

A.19. Front of soil pit classification sheet for Interpretive Trail \# $0 \ldots \ldots \ldots \ldots \ldots \ldots \ldots \ldots \ldots \ldots . . . . . . . . . . .76$

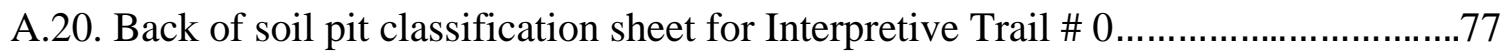

A.21. Front of soil pit classification sheet for Interpretive Trail \# 2..................................78

A.22. Back of soil pit classification sheet for Interpretive Trail \# 2 ….............................79

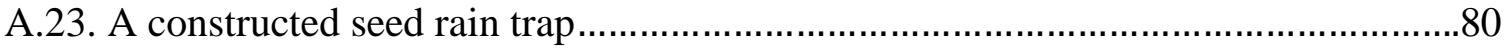

A.24. Map of available fire history at the Big Creek Reserve properties...........................81

A.25. Map of available fire history at Pfeiffer Big Sur State Park....................................82 


\section{INTRODUCTION}

Forest ecosystems are invaluable ecological and sociocultural resources, which are shaped by historical disturbance regimes. While disturbance is a natural process in all ecosystems, climate change will affect the frequency and intensity of disturbances in the future, potentially leading to unpredictable disturbance regimes. Although ecosystems are often able to maintain natural functioning and associated ecosystem services following a disturbance to which they are adapted, altered disturbance conditions can lead to lowered ecosystem tolerance to change (Johnstone et al. 2016). Therefore, increased frequency and intensity in disturbance regimes may exert unpredictable, non-additive stresses on ecosystems, leading to novel conditions that exceed an ecosystem's capacity to survive and regenerate (Buma and Wessman 2011, Metz et al. 2013). Understanding of the effects of novel disturbance conditions requires a heightened emphasis on forest resilience, the ability to absorb and adapt to ongoing change (Walker et al. 2004), and the mechanisms that confer resilience (Johnstone et al. 2016). Long-term ecosystem function is at increased risk when resilience mechanisms (e.g., seed dispersal or resprouting that spur regeneration) have not yet recovered from previous disturbances before a subsequent event occurs (Buma 2015). For example, human-driven decreases in time between fires has led to compositional shifts in boreal (Weir and Johnson 1998) and tropical (Barlow and Peres 2008) forests. In the western United States, coast redwood (Sequoia sempervirens (D. Don) Endl.) forests can experience unexpectedly high mortality from compounding disease and fire disturbances (Metz et al. 2013). Compounding disturbances occur when multiple ecosystem perturbations are either concurrent (e.g., disease and fire) or occur closely enough in time that recovery from the first disturbance 
is not complete before additional disturbances occur (e.g., two fires in rapid succession; Paine et al. 1998). Research into the viability of resilience mechanisms over a sequence of time since disturbance can inform management decisions under regimes of increasingly frequent disturbance and higher mortality (Johnstone et al. 2016).

Regeneration is a key mechanism of post-disturbance forest resilience but can decrease markedly following increased disturbance intensity and duration. For example, stand-replacing wildfire in a non-serotinous mixed conifer southern Californian forest decreased regeneration of several conifer species and extirpated three at the stand level, resulting in changes to forest composition favoring oak species (Goforth and Minnich 2008). Conifer regeneration was reduced following high local wildfire severity compounded by medium and high severity windthrow in a subalpine forest in Colorado (Buma and Wessman 2011). Salvage logging following fire has also led to significantly reduced conifer regeneration compared to burn-only areas (Donato et al., 2006). Drivers of regeneration, such as climate (Gómez-Aparicio et al. 2005), viability of seed material post-disturbance (Buma and Wessman 2011), nurse effects of established vegetation (Castro et al. 2004, Gómez-Aparicio et al. 2005), soil moisture (Urbieta et al. 2011), and seed source availability (Vacchiano et al. 2014) are current topics of research in the study of forest resilience. However, attention to other controls on regeneration that would be heightened by compounding disturbances, such as changes to soil quality from belowground disturbance legacies, is less common. In one study, mineral soil black carbon stocks decreased (but not significantly) in a Colorado subalpine forest with increasing numbers (1-3) of compounding disturbances (Buma et al. 2014). Yet overall, 
changes in regeneration controls following compounding disturbances remain a major knowledge gap in understanding forest resilience to altered disturbance regimes.

Soil legacies, the functional modifications to soil that linger after disturbances, can exert a strong influence over regeneration density (Vacchiano et al. 2014). The frequency and severity of disturbances influences the production of soil legacies (Certini 2005), including both surface and belowground properties such as mineral soil exposure, aggregate stability, exchangeable $\mathrm{K}$ and $\mathrm{Mg}$, CEC, total $\mathrm{N}$, and long-term accumulation of organic carbon (Johnson and Curtis 2001, Vacchiano et al. 2014). A better understanding of soil legacies and their influences are especially relevant in coast redwood forests, which are experiencing increased pressure from multiple types of disturbance, including fire (Westerling et al. 2006), Sudden Oak Death (SOD; Ramage et al. 2011), fog reduction (Johnstone and Dawson 2010), and compounding disturbances (Metz et al. 2013). It follows that novel disturbance regimes could unpredictably alter physical and chemical growing conditions in coast redwood forest soils and affect regeneration patterns for years after disturbance events, leading to changes in forest composition and structure.

Coast redwood forests are adapted to a historical low severity, high frequency fire disturbance regime. Fire return interval ranged from 6-25 years prior to European settlement (Lorimer et al. 2009), with more frequent fire in the southern subregion of the range (south of Alameda County, CA; Noss 2000) as compared to the northern subregion (north of Humboldt Bay, CA; Noss 2000) both historically and over the last century of fire suppression (Oneal et al. 2006, Lorimer et al. 2009). Regeneration of coast redwood after fire occurs largely via sprouting with sprouts outpacing associated forest species 
(Ramage et al. 2010, Lazzeri-Aerts and Russell 2014), though coast redwood seedlings may also represent a highly variable component of regeneration (Douhovnikoff et al., 2004; Lazzeri-Aerts and Russell, 2014). The mechanisms underlying this variation in regeneration strategy and success are poorly understood for coast redwood and many additional temperate forest species (e.g., regeneration density in Douglas-fir (Pseudotsuga menziesii), Donato et al. 2009a, Lazzeri-Aerts and Russell 2014) as are the drivers of regeneration response to altered soil conditions and the factors contributing to differential reproductive success following disturbance (Ramage et al. 2010, Vacchiano et al. 2014). Additional research into the effects of compounding disturbances and belowground disturbance legacies following fire can establish how these factors impact coast redwood seed and sprout regeneration and stand dynamics (i.e., changes in structure and composition) over time following historic and novel disturbance conditions. In particular, regeneration response and long-term changes in community composition from increasingly frequent fires are important but poorly understood topics in forest disturbance ecology (Donato et al. 2009b, Lorimer et al. 2009). More broadly, this type of research will contribute to the understanding of soil legacy influences on forest regeneration following novel disturbance patterns under climate change.

To fill this knowledge gap, the objectives of this research were therefore to better understand how fire disturbance history exerts controls on coast redwood regeneration, stand structure, and forest composition by: 1) assessing differences in stand structure and composition over varying times since fire disturbance and between single and compounding fire disturbance histories; 2) quantifying the effect of time since fire and single vs. compounding disturbance on nutrient levels in coast redwood forests; 3) by 
modeling coast redwood seedling and sprout regeneration as a function of soil nutrient levels, burn history, and understory light; and 4) testing for differences in seed germination and seedling growth between burn histories using a greenhouse experiment. Nutrients of interest $\left(\mathrm{NO}_{3}{ }^{-}, \mathrm{NH}_{4}{ }^{+}, \mathrm{PO}_{4}{ }^{3-}\right.$, and $\left.\mathrm{Ca}^{2+}\right)$ were selected based on previous studies (Hawkins and Robbins 2014, Trant et al. 2016) indicating their importance in the Cupressaceae family (of which coast redwood is a member) or other temperate forest ecosystems (Wardle et al. 2004, Binkley and Fisher 2013). For example, multiple species in the Cupressaceae family establish well on calcareous soils or have high foliar $\mathrm{Ca}^{2+}$ concentrations (Hawkins and Robbins 2014), which is related to both the effects of $\mathrm{Ca}^{2+}$ on $\mathrm{pH}$ and Cupressaceae tolerance to the calcareous environment (Hawkins and Robbins 2014, Trant et al. 2016). Nitrogen $\left(\mathrm{NO}_{3}{ }^{-}, \mathrm{NH}_{4}{ }^{+}\right)$and $\mathrm{PO}_{4}{ }^{3-}$ supply are also important factors in forest productivity across many species (Wardle et al. 2004, Binkley and Fisher 2013), and $\mathrm{NO}_{3}{ }^{-}$is of particular importance to western red cedar in the Cupressaceae family (Bennett and Prescott 2004). In selecting these nutrients, I hypothesized that their role in regeneration would include influencing germination by seed but additionally influencing whether parent trees sprouted more or less prolifically. Understanding the effects of altered fire disturbance regimes on soil nutrient levels and their roles in postfire regeneration will contribute to a better understanding of the less studied long-term effects of variable or compounding fire disturbance on forest communities. Changes in soil nutrient composition that influence the regeneration of one or more species would have lasting effects on post-disturbance competition and ultimately the composition and structure of forest communities following compounding disturbances. 


\section{MATERIALS AND METHODS}

Study area

This study occurred at the southern end of the coast redwood range in the Big Sur ecoregion of California's Central Coast, stretching roughly from Carmel in the north (N 36.536072, W 121.92801) to San Simeon in the south (N 35.645379, W 121.1914797; Henson and Usner 1993). Climate in Big Sur is Mediterranean with dry summers, wet winters, and cooler summer temperatures than other Mediterranean climates due to abundant summer fog (Henson and Usner 1993). Precipitation (Table 1) ranges from 67.61 to 99.29 average cm per year from the southern to northern portion of my study range in Big Sur (Western Regional Climate Center 2016a, 2016b) and in general throughout the region; it is highest in the coastal Santa Lucia Mountains (Davis and Borchert 2006). The region supports a mosaic of ecosystems including coastal prairie and maritime chaparral, oak woodlands, mixed evergreen forests, and mixed conifer forests among others due to the varied topography of the coast and mountain terrain (Henson and Usner 1993, Davis and Borchert 2006). Coast redwood forests are limited in Big Sur compared to other forest types (Metz et al. 2012). In this southern extent of the coast redwood range the species is often confined to canyons where fog settles and northfacing, well-drained slopes due to moisture limitations (Henson and Usner 1993, Noss 2000). Here, coast redwood can co-occur with big leaf maple (Acer macrophyllum), white alder (Alnus rhombifolia), tanoak (Lithocarpus densiflorus), western sycamore (Platanus racemosa), bay laurel (Umbellularia californica), and Douglas-fir depending on topography and associated moisture (Borchert et al. 1988, Henson and Usner 1993). In coast redwood forests in this region, the Gamboa and Sur soil series are most common (the Gamboa-Sur complex); the two are very similar, but the Gamboa series is deep and 
productive while the Sur is considered to be less so (Borchert et al. 1988). These soils are typically well-drained, gravelly or very gravelly loams with roughly neutral $\mathrm{pH}$ (Borchert et al. 1988). These two series have been documented on sandstone, schist, granite, marble, gneiss, and quartz parent materials in the area (Borchert et al. 1988).

Site descriptions

My primary goal in site selection was to identify locations with varying but evenly spaced amounts of time since last fire disturbance in Big Sur. In the North Coastal Santa Lucia Range, more than 50\% of all land has been burned at least once since 1950 (Davis and Borchert 2006). However, access to sites with burned coast redwood forest was my primary limiting factor in selection, as 95\% of the annual burn area in the Los Padres National Forest where this study was located is chaparral rather than forest (USDA

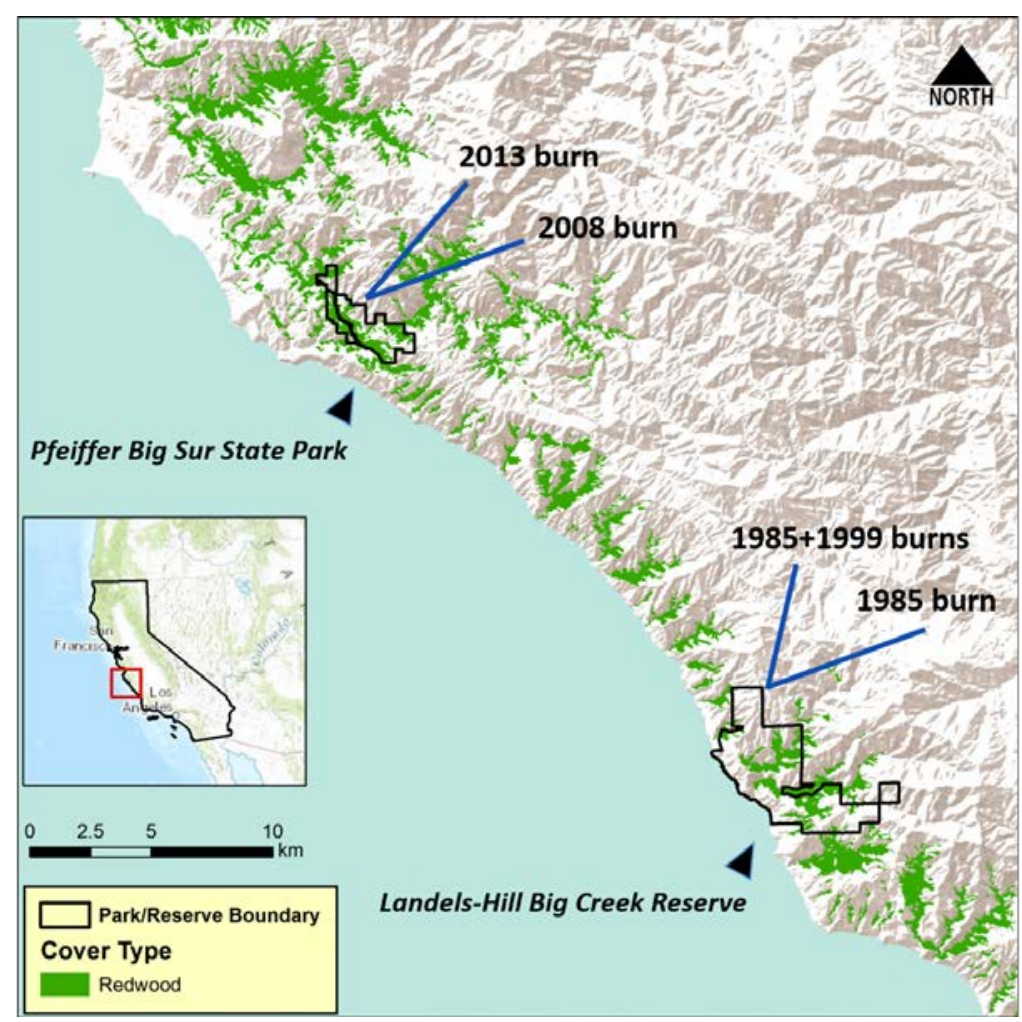

Figure 1. Map of study areas in Big Sur, California. 
1988). Additionally, I selected sites with as much similarity in aspect, elevation, topography, and underlying soils as was possible given my geographic framework.

My final site selections included two burn events at Landels-Hill Big Creek Reserve (Big Creek; N 36.0719782, W 121.6024008, Figure 1) and two burn events at Pfeiffer Big Sur State Park (Pfeiffer; N 36.25, W 121.783333; Figure 1). Big Creek provided my two oldest burn histories: one area burned in 1985 and a second burned both in 1985 and 1999 (Figure A.2; Mark Readdie, personal communication; Department of Forestry and Fire Protection 2015). The 1985 Gorda-Rat fire consumed 22,662 hectares (United State Forest Service 1986), burning the majority of the Big Creek property. I used this fire as the earliest fire event in order to create a timeline from 1985 to present. The second burn site at Big Creek was located in an area last burned in the 1999 Kirk fire but also burned in the 1985 Gorda-Rat fire, making this a compounding burn history. The Kirk fire consumed 35,086 ha and burned more than half of the Big Creek property (National Interagency Fire Center, n.d.). Available fire perimeter data for Big Creek show that fires have impacted the property roughly every 11 years since 1911 (Figure A.24; Department of Forestry and Fire Protection 2015). Burned areas in Pfeiffer comprised my two most recent burn events: one area burned in 2008 and a second burned in 2013 (Figure A.3; Department of Forestry and Fire Protection 2015). The 2008 Basin-Complex fire burned 65,890 ha, including much of the northwestern portion of Pfeiffer (InciWeb 2008, Department of Forestry and Fire Protection 2015), whereas the 2013 Pfeiffer fire burned 371 ha in a small portion of the park’s southwestern edge (InciWeb 2013). Available fire perimeter data for Pfeiffer show that fires have impacted the property roughly every 18 years since 1924 (Figure A.25; Department of Forestry and Fire 
Protection 2015). The 1985, 2008, and 2013 burn histories corresponded to one soil type in the NRCS Web Soil Survey (Figures A.4-6; Soil Survey Staff 2014): Gamboa-Sur complex (Gamboa: Haploxerolls, Sur: Haploxerolls; Soil Survey Staff 2003). The 1985/1999 burn history was from the McCoy series and rock outcrop-Xerorthent association (Figure A.4). Like Gamboa and Sur, the McCoy series is a moderately deep and well-drained Mollisol (Argixerolls) but with a higher clay content (Soil Survey Staff 2003, Ludington et al. 2005). Soil pits at each burn site confirmed that underlying soils were very similar across burn histories (see taxonomic classifications in Table 1; soil pit results presented in Table 2). Additional site data are described in Table 1.

I selected two sampling locations from each burn history with similar aspect, elevation, topography, and coarse soil designations. Within each sampling location, I randomly placed ten 0.01 ha sampling plots ( 10 plots $\mathrm{x} 2$ locations $\mathrm{x} 4$ burn histories $=80$ plots).

\section{Plot selection and data collection}

Within each 0.01 ha plot, I sampled and mapped all overstory trees and saplings ( $>2.5$ cm diameter \& $>1.37 \mathrm{~m}$ height). All overstory trees were tagged and sampled for species, diameter at breast height, health status, relative height of tree burned, canopy class, decay class (if applicable), and visual symptoms of pathogens. I also sampled and mapped a subset (10\%) of clumped sprouts and all seedlings. I defined sprouts and seedlings as individuals $<1.37 \mathrm{~m}$ in height and $<=2.5 \mathrm{~cm}$ diameter at base; seedlings were considered any stems meeting these height and width measurements that were also $>/=1$ m away from a mature tree. Each sprout or seedling to be mapped was tagged and sampled for species, diameter at base, health status, and visual symptoms of pathogens. 


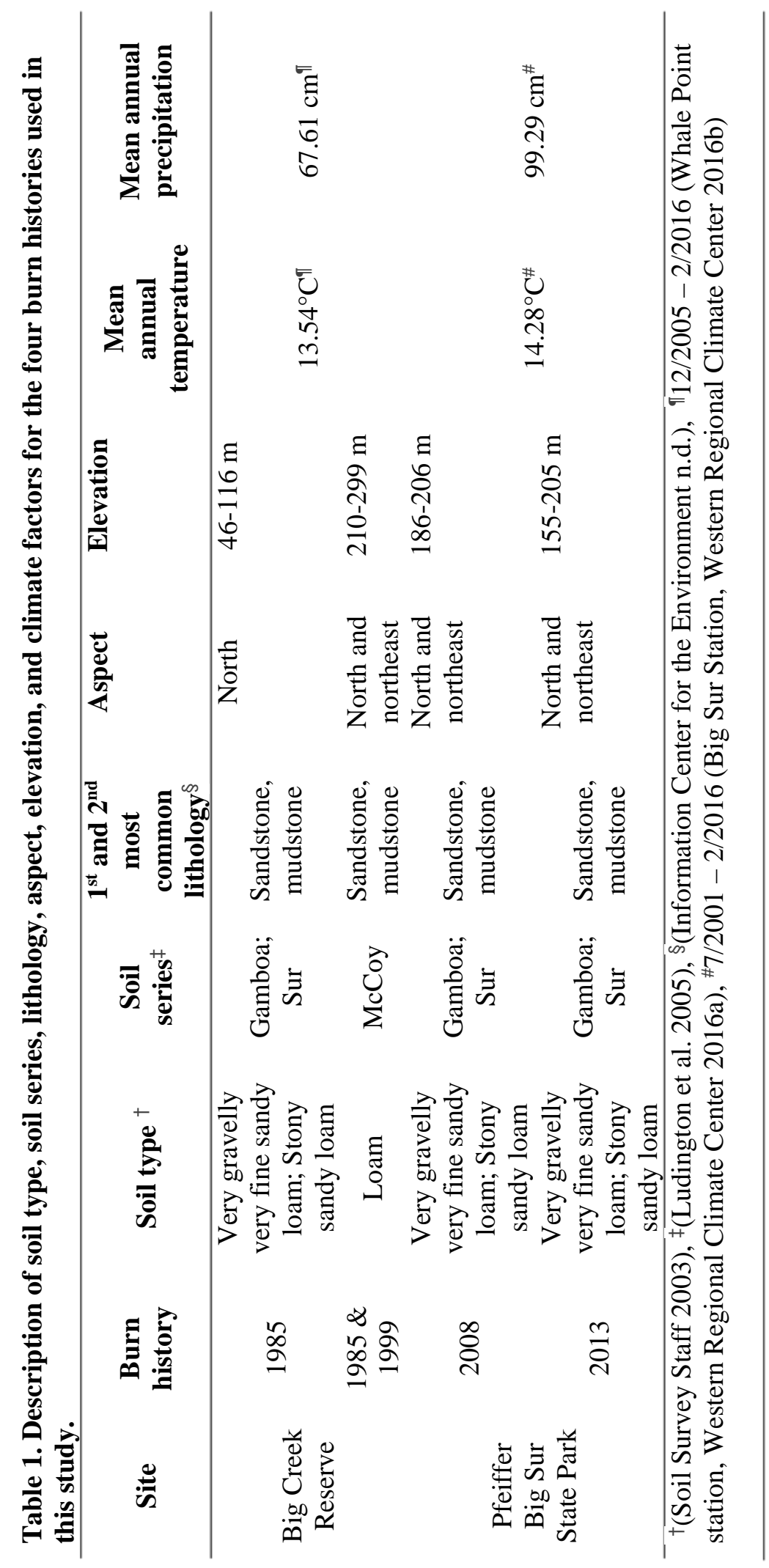


In addition to sampling the forest community, I also quantified abiotic variables relevant to tree regeneration, including understory light availability and soil nutrient levels. I assessed total available light using hemispherical photography by taking a 180 degree hemispherical photograph at $1 \mathrm{~m}$ above the ground at the center of each 0.01 ha subplot and under overcast or early morning conditions. I used Gap Light Analyzer (version 2.0, Frazer et al. 1999) to process photos and calculate percent total transmitted light (diffuse and direct) available at each subplot center. Soil samples were also collected within each of the 800.01 ha plots. Sampling for chemical analysis and detection of soil legacies from disturbance occurred over the course of a few days in May 2016 to control for inter- and intra-seasonal variation in nutrient availability. Litter and duff layers were discarded from the soil surface, and soil samples were collected from the A horizon (0-10 $\mathrm{cm}$ depth) to capture the rooting zone of early regeneration (sensu Vacchiano et al. 2014). Twelve equally sized soil subsamples were collected in diagonals running between corners in each plot: six were collected along each diagonal (for a total of 12) and mixed for a composite sample.

I collected soil and seed samples from one area in each burn history in order to run a greenhouse trial testing the strength of seedling regeneration and whether or not soil legacies from burn history influenced growth rates of regeneration observed in my field sampling. Approximately six gallons of soil were collected from 0-10 cm depth in an area adjacent to my sampling subplots in each burn history $(6$ gallons $\mathrm{x} 4$ burn histories $=24$ gallons), which was representative of both overstory tree composition and belowground soil characteristics. Seed samples were collected using permanent $\sim 0.5 \mathrm{~m}^{2} \mathrm{PVC}$ traps 
with mesh netting to collect falling seed material. Traps were installed in early fall 2015 and emptied twice throughout the fall 2015 and winter 2016.

\section{Lab and greenhouse studies}

Soil samples for nutrient analysis were air dried to a constant weight, sieved prior to analysis (using a 2mm screen), and sent to A\&L Western Agricultural Labs (Modesto, CA, USA) for processing for $\mathrm{NO}_{3}{ }^{-}, \mathrm{NH}_{4}{ }^{+}, \mathrm{PO}_{4}{ }^{3-}$, and $\mathrm{Ca}^{2+}$ concentrations.

Field-collected seed and soil from each of the burn histories was collected in large enough volume to allow for 32 replicates of four burn histories (4 burn histories x 32 replicates $=128$ samples $)$. To increase the probability of capturing viable seed from each location, seed collection began in the fall of 2015 during peak cone ripeness using five randomly placed seed rain traps in both sampling locations of each burn history. A trial run of seeds was processed using a float test in water to distinguish viable seeds from unviable seeds (the specific gravity method; sensu Demelash et al., 2003). Seeds were floated in DI water for 24 hours on a shaker table. Both floating and sinking seeds were germinated in freezer bags, and the results of the float test showed no difference in viability of seed that floated and seed that sank. Overall, germination was 6\% (on average $6+/-5.2 \%$ (SD) of seeds per provenance germinating), with $2.5 \%$ of all floating seeds germinating and 3.5\% of all sinking seeds germinating. As a result of this, I did not attempt to separate viable seed from unviable seed prior to my greenhouse study.

Soil from each burn history was air-dried to a constant weight and placed on top of a layer of gravel in $655.48 \mathrm{~cm}^{3}$ seedling pots from Stuewe \& Sons (Tangent, Oregon), and each pot seeded with 20 coast redwood seeds for initial germination. One third of each seedling pot was filled with gravel and two thirds were filled with soil. The total number 
of germinated seeds was recorded for each pot over the course of a three-month period. During the growing period the pots were stored in a greenhouse set to maintain an average temperature of $21.1^{\circ} \mathrm{C}$ over the course of each day. Pots were not fertilized during the course of the study and were watered by hand every other day to maintain a consistently moist substrate just below the soil surface.

\section{Methods of analysis}

I tested for differences in average basal area per subplot, understory light, and soil nutrient levels following burn events and then modeled coast redwood regeneration as a function of soil qualities and abiotic site variables. I used Welch's ANOVA to compare average basal area per subplot, percent total understory light, and soil nutrient levels between burn histories and employed Tukey's HSD test to distinguish between burn histories for instances where an ANOVA global $F$ test was significant at the 5\% level. I used a generalized linear mixed model (GLMM) with a negative binomial distribution and log link function to model counts of overdispersed coast redwood seedlings in each random subplot as a function of burn history, levels of soil nutrients, and percent available light (Bolker 2015). I tested a full model including the following fixed effects: number of years since last burn (numeric), single vs. compounding burn history, percent total understory light, $\mathrm{Ca}^{2+}, \mathrm{PO}_{4}{ }^{3-}, \mathrm{NO}_{3}{ }^{-}$, and $\mathrm{NH}_{4}{ }^{+}$to determine whether nutrient levels across varying burn histories were drivers of redwood regeneration. I used a random effect to control for variance due to differences in the two sampling locations used in each burned area (eight levels). Analysis of residual plots revealed one outlying data point ( $>3$ times interquartile range) due to a high $\mathrm{NO}_{3}{ }^{-}$measurement. This plot was removed from my final modeling analysis. Statistical analyses were run in R statistical 
programming software (R Core Team 2015), with the Ime4 package employed for GLMM analysis (Bates et al. 2015).

I additionally assessed whether forest community composition differed between burn histories using a multi-response permutation procedure (MRPP) in the vegan package for R statistical programming software (R Core Team 2015, Oksanen et al. 2016). I used two MRPPs to test the null hypothesis that there was no difference in species composition between burn histories for mature trees $(>/=10 \mathrm{~cm} \mathrm{dbh})$ and the post-fire regeneration community (<10 cm dbh) (McCune and Grace 2002). Multi-response permutation procedure is a multivariate, nonparametric technique that provides a chance-corrected within-group agreement statistic $(A)$ comparing the observed within-group distance to the mean within-group distance of all partitions of the data and a probability of having the observed mean within-group distance considering the distribution of possible withingroup distances (McCune and Grace 2002, Pidgen and Mallik 2013). I used the Sørensen (Bray-Curtis in vegan) dissimilarity index and default group weights in the vegan package for my calculations. Data from several 0.01 ha subplots were removed prior to analysis of the mature forest community due to the absence of mature trees from all woody species. I also used the vegan package to produce a Nonmetric Multidimensional Scaling (NMS) ordination with the Sørensen dissimilarity index and 100 iterations to visually assess differences in the forest community composition between burn histories.

Analysis of the greenhouse data was carried out using a Fisher's exact test to assess the null hypothesis that proportions of coast redwood seed germination were independent of the burn history of the soil in which they were grown. 


\section{RESULTS}

\section{Ecological conditions}

Across all four of my burn histories, I encountered a total of four different tree species: coast redwood, tanoak, bay laurel, and live oak (Quercus wislizenii). Coast redwood was the most common of these species, accounting for $71.2 \%$ of living mature stems in all subplots. The dominance of coast redwood was further emphasized by its overrepresentation in basal area: it accounted for $95.6 \%$ of living mature basal area in my study. Tanoak, bay laurel, and live oak accounted for $10.4 \%, 17.5 \%$, and $0.9 \%$ of living mature stems and $0.4 \%, 2.8 \%$, and $1.2 \%$ of living mature basal area, respectively. Regeneration was also dominated by coast redwood, with $75.5 \%$ of regeneration stems, compared to $11.5 \%, 10.8 \%$, and $2.2 \%$ for tanoak, bay laurel, and live oak, respectively.

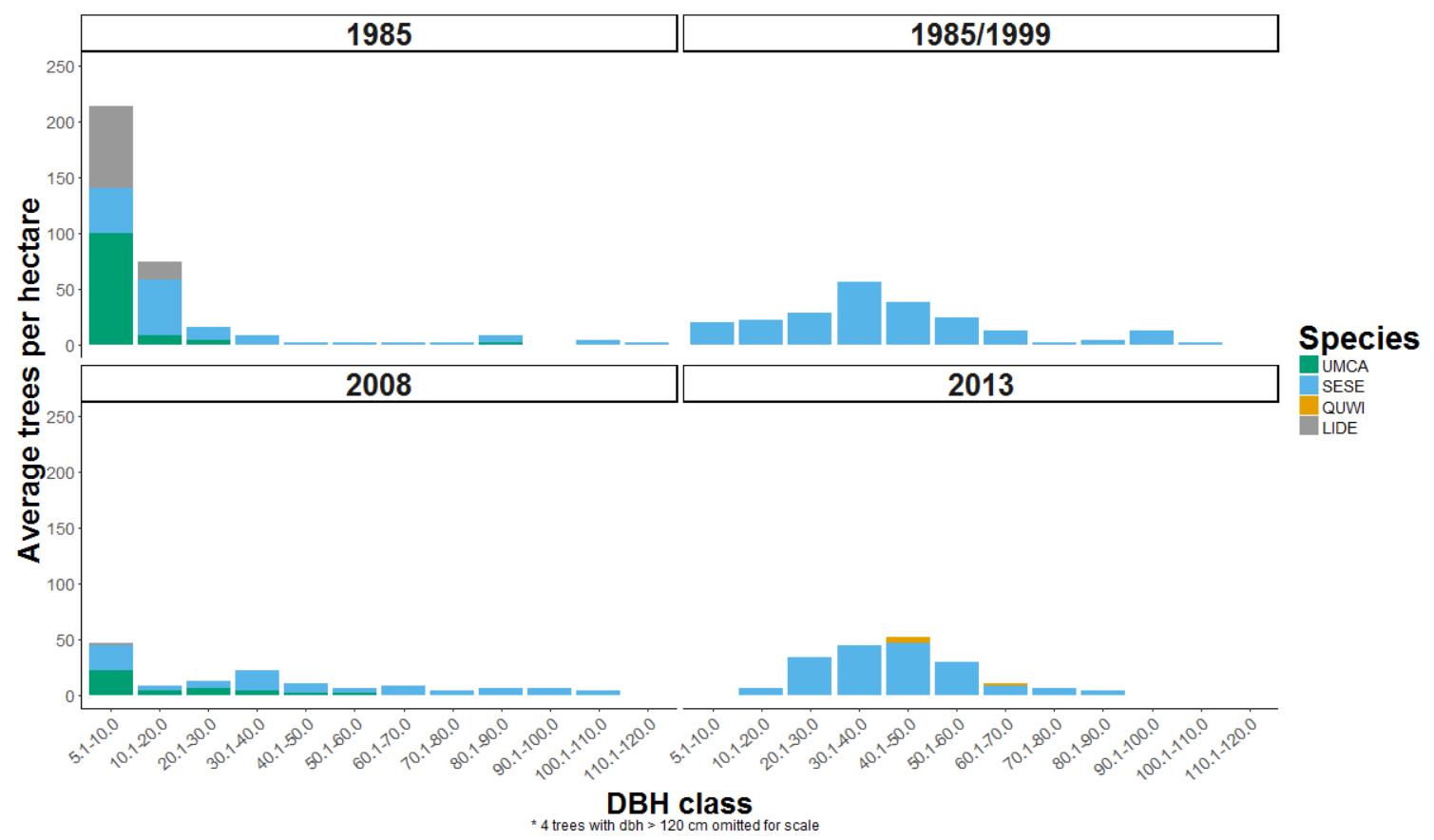

Figure 2. Distribution of overstory ( $>5 \mathrm{~cm}$ diameter at $1.37 \mathrm{~m}$ height) tree diameter size classes across four burn histories by average trees per hectare (TPH). The 1985/1999 burn history was burned twice and is considered a compounding disturbance. 
Live oak only showed up in seven subplots in the 2013 burn and one subplot in the 2008 burn. The 2013 burn and 1985/1999 compounding disturbance were the most similar burn histories, having similar species compositions (Figure 2) and the two highest average per-subplot basal areas. The 1985 and 2008 burn histories had the greatest diversity of tree species, with tanoak and bay laurel almost entirely absent from 2013 and the compounding disturbance and overall being very homogenous. Average basal area ha' ${ }^{1}$ plot $^{-1}$ was greatest in the 1985/1999 compounding burn history $\left(89.73+/-65.86 \mathrm{~m}^{2}\right.$ ha $^{-}$ $\left.{ }^{1}\right)$, followed by $2013\left(73.20+/-55.10 \mathrm{~m}^{2} \mathrm{ha}^{-1}\right), 2008\left(72.63+/-112.14 \mathrm{~m}^{2} \mathrm{ha}^{-1}\right)$, and 1985 $\left(63.24+/-94.20 \mathrm{~m}^{2} \mathrm{ha}^{-1}\right)$; differences between years were not statistically significant $(F=$ $0.4118 ; P=0.7454)$. The results of soil pits I dug to verify published soil survey information showed that the soils on my sites were mostly uniform and similar to my expectations based on soil survey data (Table 2). Higher clay soils were generally more common on my sites than predicted by the soil survey data (i.e., more Argixerolls than Haploxerolls), but the predominant pattern was one of Mollisols with high levels of rock fragments near the surface. Understory light content in four burns were significantly different ( $F=7.6030 ; P=0.0002$ ), with the 2013 and 2008 burns having significantly more understory light than the 1985 burn but statistically similar levels to the 1985/1999 compounding burn. 


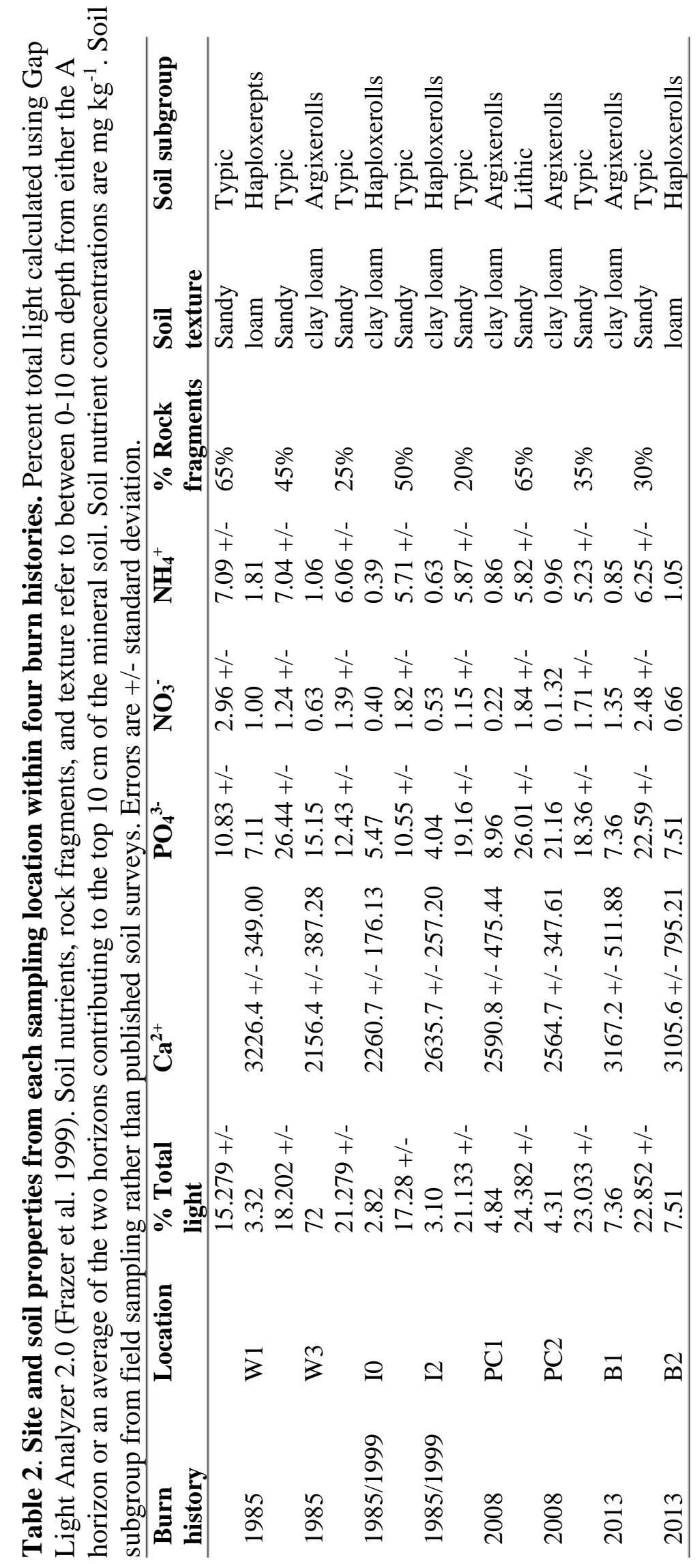




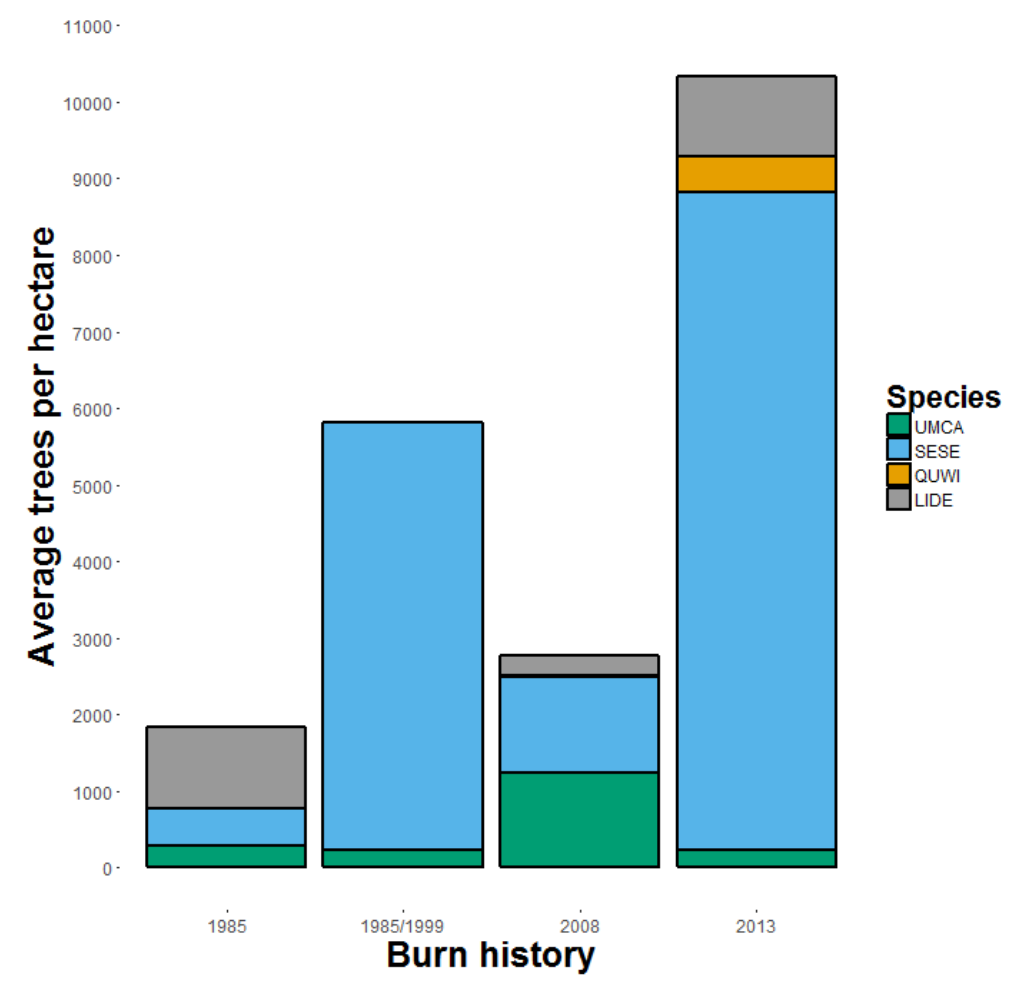

Figure 3. Species makeup for regeneration in the $0-2.5 \mathrm{~cm}$ diameter class (diameter at $1.37 \mathrm{~m}$ height) across four burn histories by average trees per hectare (TPH). The 1985/1999 burn history was burned twice and is considered a compounding disturbance.

I mapped and sampled all overstory trees and saplings and understory tree regeneration in order to assess whether amount of time since fire and compounding vs. single fire disturbance histories had an influence on long-term stand structure and composition in my forest plots. Diameter distribution plots (Figures 2 and 3) generated from stem mapping in my stands showed distinct differences between the four burn histories. In all burn histories, the average number of trees per hectare (TPH) was highest in small sizes classes (0-2.5 cm and 2.6-10.0 cm dbh). However, in the two oldest single disturbance histories (1985 and 2008), the diameter distributions show patterns typical of 
uneven-aged stands, compared with irregular uneven-aged stand characteristics in the diameter distributions of the compounding disturbance (1985/1999) and even-aged in the most recent single disturbance history (2013). The compounding disturbance history and the 2013 single disturbance event had the highest levels of overall regeneration $(0-2.5 \mathrm{~cm}$ dbh stems) and were similar in that coast redwood was dominant in both histories.

Differences between burn histories were also borne out in the MRPP analysis and NMS ordination for both mature $(>/=10 \mathrm{~cm} \mathrm{dbh} ; A=0.1232 ; P=0.001)$ and immature $(<10$ cm dbh; $A=0.1595 ; P=0.001)$ forest communities. These analyses indicated that there were significant differences between the four post-burn communities, and that withingroup similarity (homogeneity) for the burn communities was higher than is often expected in community ecology datasets (i.e., observed $A$ values $>0.10$; McCune and Grace 2002). The 2013 and 1985/1999 compounding burn histories showed the smallest amounts of dispersion based on the observed average within-group distances (Table 3) indicating high levels of species similarity within these burn communities. The 2013, 2008, and compounding burn history overlapped the most in the NMS ordination plots 
(Figure 4), showing that these communities were the most similar to one another and reinforcing the patterns of similarity between them from the diameter distribution plots. 

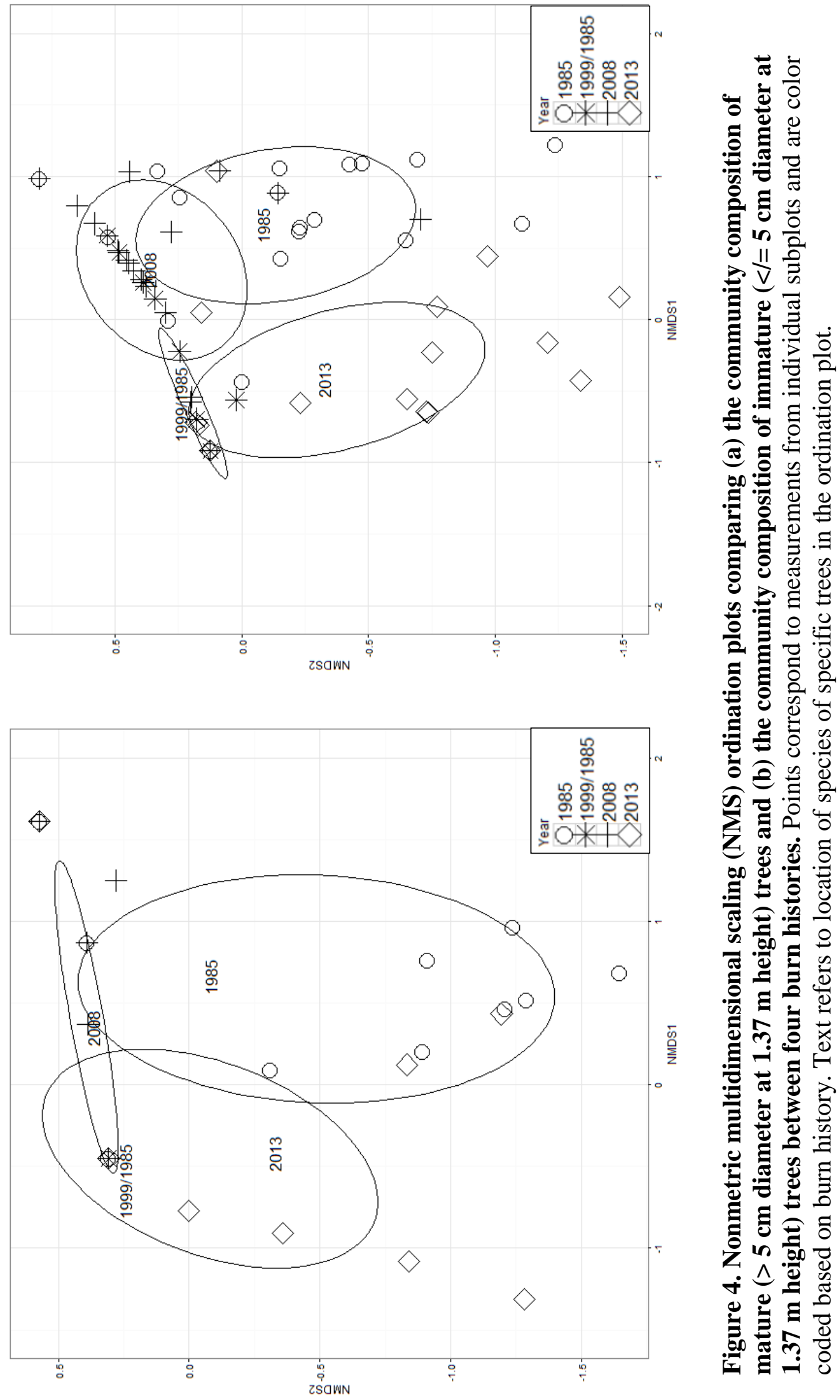
By contrast, 2013 and 1985 burn histories were the most separated from each other. Nutrient levels

I collected soil samples from each of the four burn histories in order to determine whether the amount of time since last fire disturbance or single vs. compounding fire histories left measurable soil legacies in my study areas. The results of ANOVA between burn histories for $\mathrm{Ca}^{2+}, \mathrm{PO}_{4}{ }^{3-}, \mathrm{NO}_{3}{ }^{-}$, and $\mathrm{NH}_{4}{ }^{+}$showed differences between burn histories for these nutrients. Comparisons between burn histories for $\mathrm{Ca}^{2+}$ showed significantly higher levels in the 2013 burn history ( $F=6.2395$; $P=0.0014$; Figure 5a). Phosphorus levels were significantly highest in the 2008 burn, and lowest in the compounding 1985/1999 burn history ( $F=8.6996 ; P=0.0002$; Figure 5b). For nitrogen, $\mathrm{NO}_{3}{ }^{-}$levels did not significantly differ between burn histories $(F=2.0433 ; P=0.1235)$ but $\mathrm{NH}_{4}{ }^{+}$ levels were significantly higher in the area burned once in $1985(F=4.2612 ; P=0.0106$;

Figure 5c and 5d). I did not observe any strong trends of soil legacy change over time in

Table 3. Output of MRPP analysis for community composition between four burn histories, including a compounding fire history burned both in 1985 and 1999. Within-group distance refers to the level of clustering within burn history communities. A compares the observed within-group distances to the mean withingroup distances of all possible partitions of the data.

\begin{tabular}{|c|c|c|c|c|}
\hline & \multicolumn{4}{|c|}{ Average within-group distance } \\
\hline & 1985 & $1985 / 1999$ & 2008 & 2013 \\
\hline \multicolumn{5}{|l|}{ Mature community } \\
\hline$A=0.1232 ; P=0.001$ & 0.701 & 0.3737 & 0.6138 & 0.4933 \\
\hline Regeneration & 06821 & 05351 & 06100 & 05665 \\
\hline$A=0.1595 ; P=0.001$ & 0.0021 & - & 0.0175 & 0.0000 \\
\hline
\end{tabular}


Table 4. Fixed effect predictors of coast redwood regeneration from the final GLMM model selection. Time since burn refers to number of years since last fire disturbance. Single disturbance is part of a categorical variable in which compounding (twice burned) history is the baseline value. $\mathrm{NO}_{3}$ refers to nitrate concentration at a subplot level.

\begin{tabular}{lll}
\hline \multicolumn{1}{c}{ Variable } & Coefficient & $\boldsymbol{P}$ value \\
\hline Time since burn & -0.11639 & $<0.0001$ \\
Single disturbance & -1.67798 & $<0.0001$ \\
$\mathrm{NO}_{3}$ & 0.64005 & 0.0009 \\
\hline
\end{tabular}

my burn histories, but fire left a short-term peak in $\mathrm{Ca}^{2+}$ and compounding disturbance resulted in lower $\mathrm{PO}_{4}{ }^{3-}$ levels than single burn events.

Regeneration dynamics

Using a full GLMM I tested whether $\mathrm{Ca}^{2+}, \mathrm{PO}_{4}{ }^{3-}, \mathrm{NO}_{3}{ }^{-}, \mathrm{NH}_{4}{ }^{+}$, percent total light, burn, and single vs. compounding disturbance history were important predictors of coast redwood regeneration. The results of my full model showed that percent total light, $\mathrm{NH}_{4}^{+}$, $\mathrm{Ca}^{2+}$, and $\mathrm{PO}_{4}{ }^{3-}$ were not significant predictors of the number of coast redwood seedlings or sprouts my study plots. The final model indicated that levels of coast redwood regeneration increased with increasing soil nitrate levels, and regeneration decreases were associated with larger amounts of time since fire and once-burned site history (Table 4). Greenhouse study

Germination in the greenhouse study was lower than in the pre-study float test. The total number of seeds that germinated over three months was 41 out of a total of 2,560 (1.6\%; Table 5). The two most recent single burn histories (2008 and 2013) had the highest numbers of seeds germinate, but the results of the Fisher's exact test showed that there were no significant differences between burn histories $(P=0.309)$. These 
Table 5. Number of coast redwood seeds that either germinated or did not germinate in soil from each of four burn histories. Includes a compounding fire history burned both in 1985 and 1999.

\begin{tabular}{lcc}
\hline \multicolumn{1}{c}{ Soil burn year } & Germinated & Not Germinated \\
\hline 1985 & 7 & 633 \\
$1985 / 1999$ & 8 & 632 \\
2008 & 11 & 629 \\
2013 & 15 & 625 \\
\hline
\end{tabular}

germination results supported my decision to model all coast redwood regeneration as one variable in my model, rather than dividing seedlings and sprouts into separate models. The role of seed regeneration in my study areas is likely very small and does not appear to be influenced by soil legacies from fire disturbance.
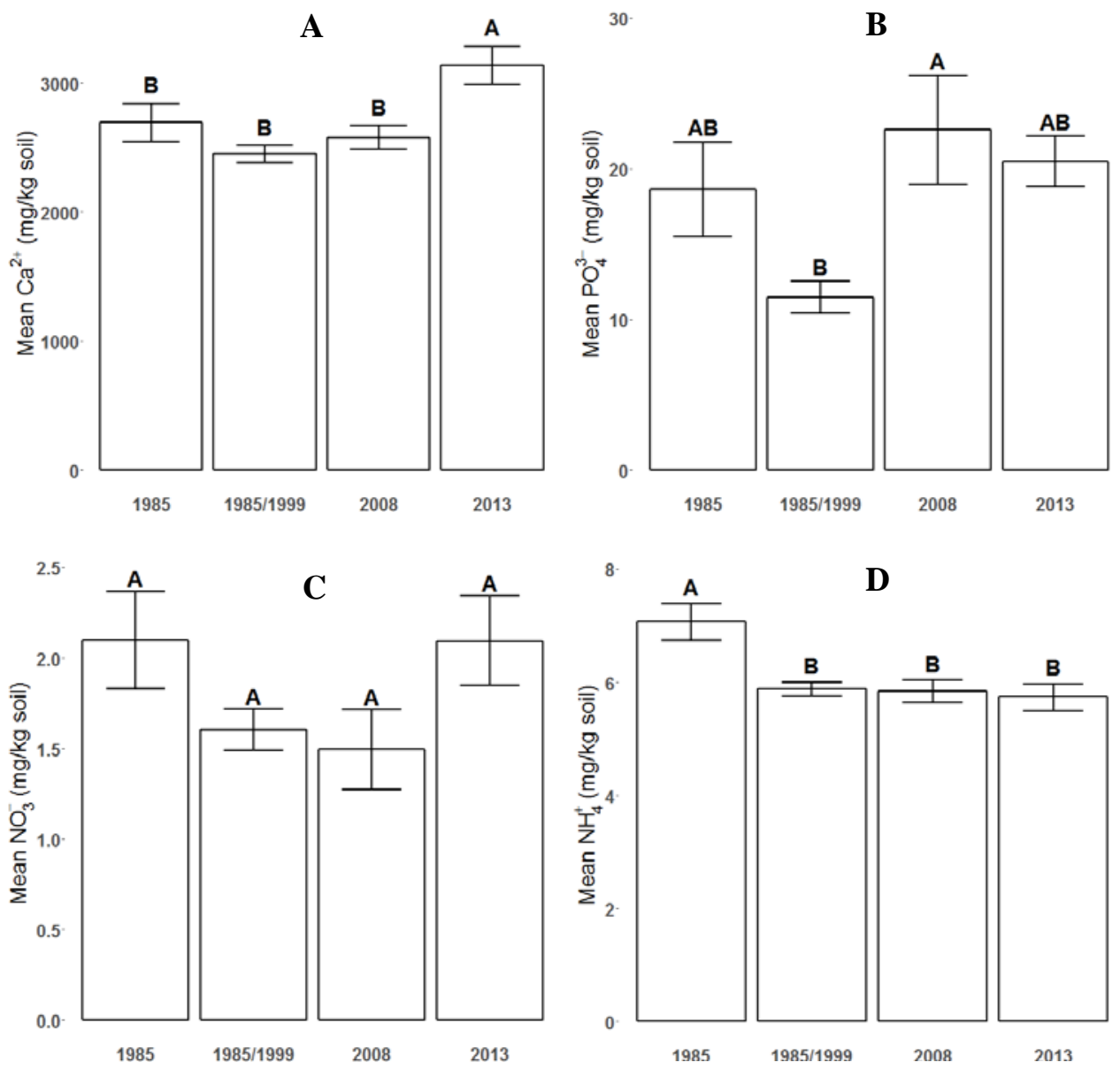

Figure 5. Levels of selected soil nutrients sampled from 0-10 cm depth across four burn histories. The 1985/1999 burn history was burned twice and is considered a compounding disturbance. Panels refer to (a) calcium, (b) phosphorus, (c) nitrate, and (d) ammonium concentration in the soil. Error bars are +/- 1 standard error. 


\section{DISCUSSION}

My results provide evidence that compounding fire disturbance resulted in more homogenized forest structure and composition than recent once-burned areas in coast redwood forests, leading to a unique forest community marked by greater dominance of coast redwood compared with co-occurring species. Compounding fire disturbance in these forests has created an environment that remains similar to more recently burned areas, even 16 years following disturbance. The 1985/1999 compounding burn and the 2013 single burn were both characterized by the decline of tanoak and bay laurel in mature and regeneration classes (Figures 2 and 3) coupled with an increase in coast redwood, creating a distinct forest community from that of the once-burned 1985 and 2008 burn histories (Figure 4). Additionally, I found that $\mathrm{Ca}^{2+}$ peaked in soil samples taken within 2.5 years following fire disturbance and then dropped to a baseline, while $\mathrm{PO}_{4}{ }^{3-}$ decreased in soils from the compounding fire disturbance (Figure 5a and b). Despite changes to $\mathrm{Ca}^{2+}$ and $\mathrm{PO}_{4}{ }^{3-}$ levels, $\mathrm{NO}_{3}{ }^{-}$was the only nutrient that significantly predicted coast redwood regeneration: increasing $\mathrm{NO}_{3}{ }^{-}$concentration was associated with increased levels of regeneration, while amount of time since burn and single disturbance history were significantly negatively related to regeneration amounts. Thus, nutrient levels influenced coast redwood regeneration post-fire, but there was not sufficient evidence that soil legacies from fire were driving this relationship. These findings support the hypothesis that the compounding disturbance drove a shift to a forest environment dominated by fire-adapted coast redwood, with species like tanoak and bay laurel not only experiencing higher mortality, but also failing to regenerate at levels comparable to more recent, single disturbances. While previous work has documented increased 
mortality in coast redwood following compounding fire and disease disturbances (Metz et al. 2013), I have found that coast redwood's sprouting response to compounding fire disturbances increases its relative dominance in the ecosystem and that species not adapted to increased frequency of fire decline relative to coast redwood.

\section{Stand structure and composition}

I found that compounding disturbance history resulted in unique post-fire forest communities distinguished by the loss of tanoak and bay laurel and increased dominance of coast redwood. Contributing to this loss was the underrepresentation of both mature tanoak and bay laurel trees compared with once-burned areas, underrepresentation of tanoak and bay laurel sprouts and seedlings in the compounding disturbance, and the significantly stronger regeneration of coast redwood even 16 years after fire in the compounding disturbance (Figures 2 and 3). It has been proposed that fire reduces tanoak dominance compared with coast redwood in recently burned areas due to higher coast redwood survival in the overstory and reduced tanoak sprout dominance in burned compared with unburned areas (Ramage et al. 2010). Yet, long-term studies of community changes following compounding fire disturbance are not available for this region. These observations and those from my study are similar to findings from the Klamath-Siskiyou Mountains (Donato et al. 2009; Oregon, USA) and Valencia, Spain (Delitti et al. 2005), which showed that broadleaved species were reduced in dominance following recurring fires. One proposed mechanism for broadleaf decline after compounding burns is the depletion of belowground carbohydrates. Several studies in Mediterranean ecosystems with fire-adapted sprouting woody species have posited that decreases in biomass or biomass increment rate after multiple recurring fires may be 
related in part to depletion of carbohydrate reserves (Trabaud 1991, Delitti et al. 2005, Enright et al. 2011). Coast redwood is more resistant to fire damage and mortality than tanoak (Ramage et al. 2010), even in compounding disturbances (Metz et al. 2013), so conceivably it would be less dependent on belowground reserves and less susceptible to compounding fire disturbance. However, in this study, tanoak showed a regeneration pattern similar to its response to sudden oak death (SOD), where at high levels of disease severity its sprouting response (resilience mechanism) is not heightened (relative to low severity levels) and the species can be replaced by coast redwood (Ramage et al. 2011). Sudden oak death is a nonnative pathogen causing extensive mortality in coastal California, especially in tanoak (Metz et al. 2012). I took note of the presence of symptoms consistent with SOD in my plots (SOD has been identified at the study sites) but explicitly identifying the disease was beyond the scope of this study. I was also unable to obtain data on pre-fire stand composition at my sites. As a result, site-specific variables such as SOD infection may be confounding factors driving community compositional changes in this study.

The effects of increased burn frequency as a result of climate change are already felt in the coast redwood forests of Big Sur (Westerling et al. 2006) and the possibility of compounding fire disturbances in Big Sur forests will increase as the frequency of fires increases this century (Westerling et al. 2011). The loss of a dominant species will homogenize the forest community, leading to cascading losses in biodiversity throughout the ecosystem (Dale et al. 2001), resulting in reduced ecological memory (Johnstone et al. 2016) and the potential for a vacant niche to be filled by a species new to these forests (Ramage et al. 2011). Disturbance alone often results in negative impacts to ecosystem 
services (Thom and Seidl 2015), but reduced diversity in coast redwood forests would also result in less flexibility and response capacity for future disturbance stressors (Luck et al. 2003). Ecosystem services, such as cultural recreational value (Seidl et al. 2016) of the pre-disturbance forest community would be negatively affected by forest homogenization from compounding fire disturbance. Resources for wildlife would also be adversely affected: For example, the dusky-footed woodrat depends on tanoak (Bowcutt 2014) and is a food source for predators like the spotted owl (Thome et al. 1999) and bobcat (Nussbaum and Maser 1975). Removal of tanoak resources would have a negative impact on these and other food chains. Additionally, the long-term function and health of the forest ecosystem could be compromised, as higher community diversity can help to decrease the risk of disease through the "dilution effect” (Keesing et al. 2006). Big Sur forests with high levels of community diversity may have fewer symptoms of SOD due to the presence of alternative, less susceptible hosts (Haas et al. 2011); a major reduction in abundance or diversity of the forest could provide footing for a future outbreak or novel disease. The loss of one or more species in patches of coast redwood forest affected by compounding fire disturbances could have negative biological and cultural implications that would reverberate throughout these ecosystems.

\section{Nutrient levels}

The results of my nutrient analyses indicated that some nutrients of interest underwent changes in availability following both single and compounding fire disturbances. Soil $\mathrm{Ca}^{2+}$ concentrations peaked following the most recent burn in my study, but I did not detect changes to $\mathrm{Ca}^{2+}$ concentrations longer than 2.5 years after fire or between single and compounding disturbances (Figure 5a). My analysis supports the 
findings of previous work, in which soil $\mathrm{Ca}^{2+}$ concentrations were elevated more than a year following fire in a Canadian jack pine (Pinus banksiana) barren (Smith 1970). Other studies have noted similar results with some variation: for example, increased $\mathrm{Ca}^{2+}$ for up to 21 years following wildfire in a boreal forest in Quebec (Simard et al. 2001), or for the two-year duration of a study following slash burning in eucalyptus forest (Tomkins et al. 1991). However, my findings contrast with other work documenting pulses in $\mathrm{Ca}^{2+}$ or $\mathrm{Ca}$ + Mg lasting two years or less (Khanna and Raison 1986, Alauzis et al. 2004), or one in which wildfire had no effect on mineral soil $\mathrm{Ca}^{2+}$ in a boreal forest (Brais et al. 2000). Calcium contributes to cell wall construction and responses to environmental stimuli and stressors in plants (Marschner 1995), and it is important to proper function and health of forest ecosystems (McLaughlin and Wimmer 1999, Schaberg et al. 2001). Soil Ca ${ }^{2+}$ depletion is therefore an important risk to consider following disturbance. However, my work shows that, with the exception of an ephemeral pulse, single and compounding fire disturbances alone are not likely to have long-term consequences for calcium availability to coast redwood forest species in the Big Sur region.

Phosphorus availability in the soil often increases within the first year following a fire (Romanyà et al. 1994), but it can be followed by a quicker, though more variable decline than that of $\mathrm{Ca}^{2+}$ (Macadam 1987, Certini 2005). In my study, $\mathrm{PO}_{4}{ }^{3-}$ was highest eight years post-fire and lowest in the compounding 1985/1999 burn history, but the 2013 burn and 1985 single burn were indistinguishable from one another (Figure 5b). Similarly to my findings, Ferran et al. (2005) observed that $\mathrm{PO}_{4}{ }^{3-}$ levels initially peaked following one fire, but decreased with each recurrent fire in a 16-year timeframe until reaching control levels, though this was site-dependent. Phosphorus is made available to plants by 
combustion of its organic form (Cade-Menun et al. 2000), which is an exception to its otherwise tightly closed cycle in forests (Cade-Menun et al. 2000, Binkley and Fisher 2013). Phosphorus is utilized by plants as a structural component in nucleic acids and for metabolic energy transfer (Marschner 1995). Recent research has documented the role of $\mathrm{PO}_{4}^{3-}$ in the productivity of nutrient-limited western redcedar (Thuja plicata) in coastal forests (Blevins et al. 2006, Trant et al. 2016). Although coast redwood is also a member of the Cupressaceae family and shares a similar forest type to western redcedar, I did not find similar evidence of $\mathrm{PO}_{4}^{3-}$ limitation in my study sites. Considered with the findings of Ferran et al. (2005), my work shows that compounding fire disturbances may leave a lower $\mathrm{PO}_{4}{ }^{3-}$ legacy compared with once-burned areas, though it is not clear how this compares to unburned patches in the coast redwood ecosystem. Additionally, my sampling may have missed an early peak for the most recently burned sites.

I observed elevated (but not statistically significant) soil $\mathrm{NO}_{3}{ }^{-}$levels in the most recent burn event and statistically higher soil $\mathrm{NH}_{4}{ }^{+}$levels in the oldest single burn event (Figure 5c and d). Nitrogen fluctuations in my burn histories generally followed the pattern of past research. Previous studies have documented pulses in $\mathrm{NH}_{4}{ }^{+}$for a year or more following fire with a lagged increase in $\mathrm{NO}_{3}{ }^{-}$, but increases in one or both forms of inorganic nitrogen may be gone within one to five years (Covington et al. 1991, Covington and Sackett 1992, Grogan et al. 2000). Thus, my study may have missed the period in which a pulse occurred by several months to a year. I did not measure potential mineralizable nitrogen (PMN), but Ferran et al. (2005) found patterns of increasing PMN with increasing number of compounding fire disturbances (only one site was significant). By contrast, the same authors found that total nitrogen decreased on one site with 
increasing fire frequency. Moreover, increased nitrogen availability may be the exception rather than the norm following recurring fire disturbances (Vance and Henderson 1984, Neary et al. 1999), and my data do not show clear evidence of legacies in any form of nitrogen from compounding disturbance. While there is no evidence of a nitrogen legacy in this study, I did find evidence that coast redwood is influenced by nutrient levels in this coastal forest - in this case by nitrogen availability. Nitrogen availability directly influences aboveground net primary productivity in temperate forest ecosystems (Reich et al. 1997), and particular attention should be given to investigating other disturbance events that could impact $\mathrm{NO}_{3}{ }^{-}$in nitrogen-influenced systems such as this one.

\section{Regeneration dynamics}

In this study, I found that coast redwood's response patterns to compounding disturbance and soil variables contradicted findings in other studies investigating compounding disturbance and the post-fire influence of nutrients. Buma and Wessman (2011) found that increased fire severity from compounding disturbance reduced conifer regeneration by seed eight years after a fire, and Vacchiano et al. $(2013,2014)$ found increased Scots pine (Pinus sylvestris) regeneration by seed in the Southern Alps resulting from decreases in nutrient levels after fire. In this study, $\mathrm{NO}_{3}{ }^{-}$levels and compounding disturbance were the primary determinants of coast redwood regeneration abundance. Previous studies on forest productivity have generally investigated larger changes in nitrogen availability than we observed between our sites (Van Den Driessche 1971, Bledsoe and Zasoski 1983, Devine and Harrington 2009). However, Will (1961) found that $\sim 0.5 \mathrm{ppm}$ changes (equivalent to $\mathrm{mg} / \mathrm{kg}$ ) in nitrogen concentration for lownitrogen water culture of Pinus radiata were associated with differences in height, 
weight, and visual severity of deficiency symptoms. Coast redwood's basal sprouts respond favorably to increased light (O’Hara and Berrill 2010), but light was not a determinant in coast redwood success in these post-fire communities. These results highlight the important context of species-specific resilience mechanisms and responses to disturbance history (Johnstone and Chapin 2006). Coast redwood's sprouting mechanism may enable it to immediately respond to the new conditions and available resources, allowing it to compete well for resources in regeneration sites. Moreover, my greenhouse study provided evidence to support sprouting as the primary regeneration mechanism in my study sites. As a result of the extremely low germination rates in my study, I am confident that the regeneration modeling was an accurate illustration of drivers of sprouting response in coast redwood following fire disturbance.

At the southern end of its range, coast redwood is well adapted to persist in the short term under the conditions expected with climate change. Trees in the northern extent of the range have shown larger than expected rates of growth since the 1970s despite rising temperatures, though this may be due to increased light availability (and trees at Big Creek do not show this pattern; Sillett et al. 2015). Coast redwood is also better suited to handle increasing fire frequencies expected from climate change than its broadleaved counterparts (Waring and O’Hara 2008, Lorimer et al. 2009, Ramage et al. 2010, Metz et al. 2013, Lazzeri-Aerts and Russell 2014). Because stand trajectory is dependent on regeneration patterns (Dietze and Clark 2008), compounding fire disturbance will likely contribute to altered trajectories in stand development, wherein coast redwood is retained and regenerates more successfully than tanoak or bay laurel (whose resilience mechanisms are inadequate to respond to compounding fire disturbance) (Waring and 
O’Hara 2008, Ramage et al. 2010). This will result in a different stand composition than in pre-fire conditions. According to my findings, such ecosystems will likely have similar structure and composition to more recently burned stands for long periods of time.

These forests are already under pressure from widespread SOD mortality to tanoak in the region (Metz et al. 2012), and the additional decline of tanoak and/or bay laurel following increased fire frequency and occurrences of compounding disturbance would overcome ecosystem resilience by reducing material legacies of these species (Johnstone et al. 2016). The loss of these species would affect leaf litter abundance (utilized by species like the Coast Range newt; Henson and Usner 1993), overhead cover protection for mammals (Noss 2000), forest structure for small mammals and birds (Henson and Usner 1993), and food sources for invertebrates, birds, small mammals and deer (Burns and Honkala 1990, Noss 2000, Bowcutt 2014), among other factors. Decline of tree species has resulted in biodiversity losses at multiple ecosystem levels in other forests (Tingley et al. 2002, Ellison et al. 2005, Kizlinski et al. 2002), foreshadowing the impacts to ecosystem health and composition that could be felt in this region as well.

My findings support a larger body of research showing that altered fire regimes and compounding disturbances from climate change negatively impact forest resilience by altering long-term trajectories (Buma and Wessman 2011, Enright et al. 2015, Johnstone et al. 2016). If such disturbances trends become widespread under increasing fire frequency, better disturbance-adapted species will exert pressure in forest communities leading to novel, homogenized forest composition (Millar and Stephenson 2015). Ecosystem services and ecosystem resilience to future disturbance such as disease and invasion will decline as a result (Enright et al. 2015). Additionally, my work contributes 
further evidence that certain species can accelerate changes in forest communities through their encouragement by compounding disturbance (Buma 2015). Future research should seek to evaluate the effects of compounding disturbances on tree survival, community composition of regeneration pulses, and long-term compositional changes in other ecosystems to determine additional species-specific responses to these challenges.

\section{Greenhouse experiment}

My greenhouse study results showed that coast redwood regeneration by seed is a weak mechanism of post-fire resilience in coast redwood forests of Big Sur, and it is not influenced by soil legacies from fire disturbance. Research in other plant species has shown that fire-related soil components and properties such as biochar presence and source (Solaiman et al. 2012), charcoal extract and vegetation leachate (Pierce and Moll 1994), and $\mathrm{pH}$ (Chidumayo 1994) can affect seed germination or seedling growth. However, this study suggests that any legacies of fire disturbance remaining in coast redwood forest soils multiple years post-fire do not variably influence coast redwood germination over greater amounts of time since disturbance or with compounding vs. single burn histories. It is known that coast redwood often regenerates weakly by seed (Boe 1968), but other studies found that this regeneration was at times as strong as that of vegetative sprouting (Douhovnikoff et al. 2004, Lazzeri-Aerts and Russell 2014). This study indicates that regardless of whether fire occurs in a single instance or in a compounding fire disturbance framework, sprouting will be the major means of regeneration and will promote dominance of coast redwood in the post-fire community. Future research should examine further controls on the sprout regeneration of this species and compare germination in unburned soil to that of soil burned over a range of times 
since fire to test for other potential variable effects of fire in contrast to an unburned control. 


\section{CONCLUSION}

In this study, compounding and recently disturbed forests were similar in stand structure, homogenous in species composition, and dominated by coast redwood individuals. However, compounding disturbance did not leave a detectable legacy in any soil nutrients that were influential for coast redwood regeneration. Soil legacies specific to compounding disturbances do not appear to be present, but nutrient levels appear to be limiting factors on coast redwood sprout regeneration in these forests following fire. The variable responses of coast redwood compared with other forest species show that compounding disturbances may contribute to a redwood-dominated shift in stand structure and composition in coast redwood forests due to its adaptations to fire. However, there is a potential for the decline or loss in associated forest species that are not as well adapted to these disturbances. My research supports other findings that altered disturbance regimes disrupt resilience adaptations, leading to shifts in forest composition (Enright et al. 2015). Shifts in composition may be indicative of increased vulnerability due to changes in relative success of regeneration and survival among different species (Johnstone et al. 2016). Homogenized forest structure and composition have negative implications for ecosystem services and overall function (Seidl et al. 2016). Therefore, it is important that future research examine how mechanisms of resilience respond to compounding disturbance and alter forest trajectories in other ecosystems where future disturbance may exert stronger pressure on competitively disadvantaged species. Understanding whether homogenization is a typical outcome of compounding disturbance in coast redwood and other temperate forests is necessary to predicting the 
implications of altered disturbance regimes' effects on long-term function and persistence of ecosystem services and resources. 


\section{REFERENCES}

Alauzis, M. V., M. J. Mazzarino, E. Raffaele, and L. Roselli. 2004. Wildfires in NW Patagonia: long-term effects on a Nothofagus forest soil. Forest Ecology and Management 192:131-142.

Barlow, J., and C. A. Peres. 2008. Fire-mediated dieback and compositional cascade in an Amazonian forest. Philosophical transactions of the Royal Society of London. Series B, Biological sciences 363:1787-1794.

Bates, D., M. Maechler, B. Bolker, and S. Walker. 2015. Fitting linear mixed-effects models using lme4. Journal of Statistical Software 67:1-48.

Bennett, J. N., and C. E. Prescott. 2004. Organic and inorganic nitrogen nutrition of western red cedar, western hemlock and salal in mineral N-limited cedar-hemlock forests. Oecologia 141:468-476.

Binkley, D., and R. F. Fisher. 2013. Ecology and management of forest Soils. 4th edition. Wiley-Blackwell.

Bledsoe, C. S., and R. J. Zasoski. 1983. Effects of ammonium and nitrate on growth and nitrogen uptake by mycorrhizai Douglas-fir seedlings mycorrhizal associations of forest trees can dramatically increase the ability. Plant and Soil 454:445-454.

Blevins, L. L., C. E. Prescott, and A. Van Niejenhuis. 2006. The roles of nitrogen and phosphorus in increasing productivity of western hemlock and western redcedar plantations on northern Vancouver Island. Forest Ecology and Management 234:116-122.

Boe, K. N. 1968. Cone production, seed dispersal, germination in old-growth redwood cut and uncut stands. 
Bolker, B. M. 2015. Linear and generalized linear mixed models. Ecological statistics: contemporary theory and application:309-333.

Borchert, M. I., D. Segotta, and M. D. Purser. 1988. Coast redwood ecological types of southern monterey county, California. USDA Forest Service General Technical Report.

Bowcutt, F. 2014. Tanoak conservation: A role for the California department of fish and wildlife. California Fish and Game 100:94-113.

Brais, S., P. David, and R. Ouimet. 2000. Impacts of wild fire severity and salvage harvesting on the nutrient balance of jack pine and black spruce boreal stands. Forest Ecology and Management 137:231-243.

Buma, B. 2015. Disturbance interactions: characterization, prediction, and the potential for cascading effects. Ecosphere 6:1-15.

Buma, B., R. E. Poore, and C. A. Wessman. 2014. Disturbances, their interactions, and cumulative effects on carbon and charcoal stocks in a forested ecosystem. Ecosystems 17:947-959.

Buma, B., and C. A. Wessman. 2011. Disturbance interactions can impact resilience mechanisms of forests. Ecosphere 2:1-13.

Burns, R. M., and B. H. Honkala. 1990. Silvics of North America. Agriculture Handbook 654, USDA Forest Service, Washington, DC.

Cade-Menun, B. J., S. M. Berch, C. M. Preston, and L. M. Lavkulich. 2000. Phosphorus forms and related soil chemistry of Podzolic soils on northern Vancouver Island. II. The effects of clear-cutting and burning. Canadian Journal of Forest Research 30:1726-1741. 
Castro, J., J. Castro, R. Zamora, and R. Zamora. 2004. Seedling establishment of a boreal tree species (Pinus sylvestris) at its southernmost distribution limit: consequences of being in a marginal Mediterranean habitat. Journal of Ecology:266-277.

Certini, G. 2005. Effects of fire on properties of forest soils: A review. Oecologia 143:110.

Chidumayo, E. N. 1994. Effects of wood carbonization on soil and initial development of seedlings in miombo woodland, Zambia. Forest Ecology and Management 70:353357.

Covington, W. W., L. F. DeBano, and T. G. Huntsberger. 1991. Soil nitrogen changes associated with slash pile burning in pinyon-juniper woodlands.

Covington, W. W., and S. S. Sackett. 1992. Soil mineral nitrogen changes following prescribed burning in ponderosa pine. Forest Ecology and Management 54:175-191.

Dale, V. H., L. A. Joyce, S. Mcnulty, R. P. Neilson, M. P. Ayres, M. D. Flannigan, P. J. Hanson, L. C. Irland, A. E. Lugo, C. J. Peterson, D. Simberloff, F. J. Swanson, B. J. Stocks, and B. Michael Wotton. 2001. Climate change and forest disturbances. BioScience 51:723-734.

Davis, F. W., and M. I. Borchert. 2006. Central Coast Bioregion. Pages 321-349in N. G. Sugihara, J. W. van Wagtendonk, K. E. Shaffer, J. Fites-Kaufman, and A. E. Thode, editors. Fire in California's ecosystems. University of California Press, Berkeley and Los Angeles, CA.

Delitti, W., A. Ferran, L. Trabaud, and V. R. Vallejo. 2005. Effects of fire recurrence in Quercus coccifera L. shrublands of the Valencia Region (Spain): I. plant composition and productivity. Plant Ecology 177:57-70. 
Demelash, L., M. Tigabu, and P. C. Odén. 2003. Enhancing germinability of Schinus molle L. seed lot from Ethiopia with specific gravity and IDS techniques. New Forests 26:33-41.

Department of Forestry and Fire Protection. 2015. Fire perimeters 1878 - 2014. Yearlyupdated GeoDatabase of California fire perimeters, Sacramento, CA, USA.

Devine, W. D., and C. A. Harrington. 2009. Western redcedar response to precommercial thinning and fertilization through 25 years posttreatment. Canadian Journal of Forest Research 39:619-628.

Dietze, M. C., and J. S. Clark. 2008. Changing the gap dynamics paradigm: vegetative regeneration control on forest response to disturbance. Ecological Monographs 78:331-347.

Donato, D. C., J. B. Fontaine, J. L. Campbell, W. D. Robinson, J. B. Kauffman, and B. E. Law. 2009a. Conifer regeneration in stand-replacement portions of a large mixedseverity wildfire in the Klamath-Siskiyou Mountains. Canadian Journal of Forest Research 39:823-838.

Donato, D. C., J. B. Fontaine, W. D. Robinson, J. B. Kauffman, and B. E. Law. 2009 b. Vegetation response to a short interval between high-severity wildfires in a mixedevergreen forest. Journal of Ecology 97:142-154.

Douhovnikoff, V., A. M. Cheng, and R. S. Dodd. 2004. Incidence, size and spatial structure of clones in second-growth stands of coast redwood, Sequoia sempervirens (Cupressaceae). American Journal of Botany 91:1140-1146.

Van Den Driessche, R. 1971. Response of conifer seedlings to nitrate and ammonium sources of nitrogen. Plant and Soil 34:421-439. 
Ellison, A. M., M. S. Bank, B. D. Clinton, E. A. Colburn, K. Elliott, C. R. Ford, D. R. Foster, B. D. Kloeppel, J. D. Knoepp, G. M. Lovett, J. Mohan, D. A. Orwig, N. L. Rodenhouse, W. V Sobczak, K. A. Stinson, J. K. Stone, C. M. Swan, J. Thompson, B. Von Holle, and J. R. Webster. 2005. Loss of foundation species: Consequences for the structure and dynamics of forested ecosystems.

Enright, N. J., J. B. Fontaine, D. M. J. S. Bowman, R. A. Bradstock, and R. J. Williams. 2015. Interval squeeze: Altered fire regimes and demographic responses interact to threaten woody species persistence as climate changes. Frontiers in Ecology and the Environment 13:265-272.

Enright, N. J., J. B. Fontaine, V. C. Westcott, J. C. Lade, and B. P. Miller. 2011. Fire interval effects on persistence of resprouter species in Mediterranean-type shrublands. Plant Ecology 212:2071-2083.

Ferran, A., W. Delitti, and V. R. Vallejo. 2005. Effects of fire recurrence in Quercus coccifera L. shrublands of the Valencia Region (Spain): II. Plant and soil nutrients. Plant Ecology 177:71-83.

Frazer, G., C. Canham, and K. Lertzman. 1999. Gap Light Analyzer (GLA), Version 2.0: Imaging software to extract canopy structure and gap light transmission indices from true-colour fisheye photographs, users manual and program documentation. Millbrook, NY, USA.

Goforth, B. R., and R. A. Minnich. 2008. Densification, stand-replacement wildfire, and extirpation of mixed conifer forest in Cuyamaca Rancho State Park, southern California. Forest Ecology and Management 256:36-45.

Gómez-Aparicio, L., J. M. Gómez, and R. Zamora. 2005. Microhabitats shift rank in 
suitability for seedling establishment depending on habitat type and climate. Journal of Ecology 93:1194-1202.

Grogan, P., T. D. Bruns, and F. S. Chapin. 2000. Fire effects on ecosystem nitrogen cycling in a Californian bishop pine forest. Oecologia 122:537-544.

Haas, S. E., M. B. Hooten, D. M. Rizzo, and R. K. Meentemeyer. 2011. Forest species diversity reduces disease risk in a generalist plant pathogen invasion. Ecology Letters 14:1108-1116.

Hawkins, B. J., and S. Robbins. 2014. Contrasts in growth and nitrogen nutrition of species in the Cupressaceae and Pinaceae in response to calcium. Plant and Soil 380:315-325.

Henson, P., and D. J. Usner. 1993. The natural history of Big Sur. University of California Press, Berkeley and Los Angeles, CA.

Historically Significant Wildland Fires. (n.d.). https://www.nifc.gov/fireInfo/fireInfo_stats_histSigFires.html.

InciWeb. 2008. Basin Complex. http://inciweb.nwcg.gov/incident/1367/.

InciWeb. 2013. Pfeiffer Fire. http://inciweb.nwcg.gov/incident/3761/.

Information Center for the Environment (ICE). (n.d.). Biological inventories of the world's protected areas.

Johnson, D. W., and P. S. Curtis. 2001. Effects of forest management on soil C and N storage: meta analysis. Forest Ecology and Management 140:227-238.

Johnstone, J. A., and T. E. Dawson. 2010. Climatic context and ecological implications of summer fog decline in the coast redwood region. Proceedings of the National Academy of Sciences of the United States of America 107:4533-4538. 
Johnstone, J. F., C. D. Allen, J. F. Franklin, L. E. Frelich, B. J. Harvey, P. E. Higuera, M. C. Mack, R. K. Meentemeyer, M. R. Metz, G. L. W. Perry, T. Schoenngel, and M. G. Turner. 2016. Changing disturbance regimes, ecological memory, and forest resilience. Frontiers in Ecology and the Environment 14:369-378.

Johnstone, J. F., and F. S. I. Chapin. 2006. Effects of soil burn severity on post-fire tree recruitment in boreal forest. Ecosystems 9:14-31.

Keesing, F., R. D. Holt, and R. S. Ostfeld. 2006. Effects of species diversity on disease risk. Ecology Letters 9:485-498.

Khanna, P. K., and R. J. Raison. 1986. Effect of fire intensity on solution chemistry of surface soil under a Eucalyptus paucijlora forest. Australian Journal of Soil Research 24:423-434.

Kizlinski, M. L., D. A. Orwig, R. C. Cobb, D. R. Foster. 2002. Direct and indirect ecosystem consequences of an invasive pest on forests dominated by eastern hemlock. Journal of Biogeography 29: 1489-1503.

Lazzeri-Aerts, R., and W. Russell. 2014. Survival and recovery following wildfire in the southern range of the coast redwood forest. Fire Ecology 10:43-55.

Lorimer, C. G., D. J. Porter, M. A. Madej, J. D. Stuart, S. D. Veirs, S. P. Norman, K. L. O’Hara, and W. J. Libby. 2009. Presettlement and modern disturbance regimes in coast redwood forests: implications for the conservation of old-growth stands. Forest Ecology and Management 258:1038-1054.

Luck, G. W., G. C. Daily, and P. R. Ehrlich. 2003. Population diversity and ecosystem services. Trends in Ecology and Evolution 18:331-336.

Ludington, S., B. C. Moring, R. J. Miller, K. Flynn, M. J. Hopkins, P. Stone, D. R. 
Bedford, and G. A. Haxel. 2005. Preliminary integrated geologic map databases for the United States - western states: California, Nevada, Arizona, and Washington. Macadam, A. M. 1987. Effects of broadcast slash burning on fuels and soil chemical properties in the Sub-Boreal Spruce Zone of central British Columbia. Canadian Journal of Forest Research 17:1577-1584.

Marschner, H. 1995. Mineral nutrition of higher plants. Second edition. Academic Press, San Diego, CA.

McCune, B., and J. Grace. 2002. Analysis of ecological communities. MjM Software Design, Gleneden Beach, Oregon.

McLaughlin, S. B., and R. Wimmer. 1999. Calcium physiology and terrestrial ecosystem processes. New Phytologist 142:373-417.

Metz, M. R., K. M. Frangioso, A. C. Wickland, R. K. Meentemeyer, and D. M. Rizzo. 2012. An emergent disease causes directional changes in forest species composition in coastal California. Ecosphere 3:23.

Metz, M. R., J. M. Varner, K. M. Frangioso, R. K. Meentemeyer, and D. M. Rizzo. 2013. Unexpected redwood mortality from synergies between wildfire and an emerging infectious disease. Ecology 94:2152-2159.

Millar, C. I., and N. L. Stephenson. 2015. Temperate forest health in an era of emerging megadisturbance. Science 349:823-826.

Neary, D. G., C. C. Klopatek, L. F. DeBano, and P. F. Ffolliott. 1999. Fire effects on belowground sustainability: a review and synthesis. Forest Ecology and Management 122:51-71.

Noss, R. F. 2000. The redwood forest: history, ecology, and conservation of the coastal 
California redwoods. R. F. Noss, Editor. Island Press, Washington, DC.

Nussbaum, R. A., and C. Maser. 1975. Food habits of the Bobcat, Lynx rufus, in the Coast and Cascade Ranges of western Oregon in relation to present management policies. Northwest Science 49:261-266.

O’Hara, K. L., and J. P. Berrill. 2010. Dynamics of coast redwood sprout clump development in variable light environments. Journal of Forest Research 15:131-139.

Oksanen, J., F. G. Blanchet, M. Friendly, R. Kindt, P. Legendre, D. McGlinn, P. R. Minchin, R. O’Hara, G. R. Simpson, P. Solymos, M. H. H. Stevens, E. Szoecs, and H. Wagner. 2016. Vegan: community ecology package.

Oneal, C. B., J. D. Stuart, S. Steven, and L. Fox. 2006. Geographic analysis of natural fire rotation in the California redwood forest during the suppression era. Fire Ecology 2:73-99.

Paine, R. T., M. J. Tegner, and E. A. Johnson. 1998. Compounded perturbations yield ecological surprises. Ecosystems 1:535-545.

Pidgen, K., and A. U. Mallik. 2013. Ecology of compounding disturbances: the effects of prescribed burning after clearcutting. Ecosystems 16:170-181.

Pierce, S. M., and E. J. Moll. 1994. Germination ecology of six shrubs in fire-prone Cape fynbos. Vegetatio 110:25-41.

R Core Team. 2015. R: A language and environment for statistical computing. R Foundation for Statistical Computing, Vienna, Austria.

Ramage, B. S., K. L. O’Hara, and B. T. Caldwell. 2010. The role of fire in the competitive dynamics of coast redwood forests. Ecosphere 1:1-18.

Ramage, B. S., K. L. O’Hara, and A. B. Forrestel. 2011. Forest transformation resulting 
from an exotic pathogen: regeneration and tanoak mortality in coast redwood stands affected by sudden oak death. Canadian Journal of Forest Research 41:763-772.

Reich, P. B., D. F. Grigal, J. D. Aber, and S. T. Gower. 1997. Nitrogen mineralization and productivity in 50 hardwood and conifer stands on diverse soils. Ecology 78:335-347.

Romanyà, J., P. K. Khanna, and R. J. Raison. 1994. Effects of slash burning on soil phosphorus fractions and sorption and desorption of phosphorus. Forest Ecology and Management 65:89-103.

Schaberg, P. G., D. H. Dehayes, and G. J. Hawley. 2001. Anthropogenic calcium depletion: a unique threat to forest ecosystem health? Ecosystem Health 7:214-228.

Seidl, R., T. A. Spies, D. L. Peterson, S. L. Stephens, and J. A. Hicke. 2016. Searching for resilience: addressing the impacts of changing disturbance regimes on forest ecosystem services. Journal of Applied Ecology 53:120-129.

Sillett, S. C., R. Van Pelt, A. L. Carroll, R. D. Kramer, A. R. Ambrose, and D. Trask. 2015. How do tree structure and old age affect growth potential of california redwoods? Ecological Monographs 85:181-212.

Simard, D. G., J. W. Fyles, D. Paré, and T. Nguyen. 2001. Impacts of clearcut harvesting and wildfire on soil nutrient status in the Quebec boreal forest. Canadian Journal of Soil Science 81:229-237.

Smith, D. W. 1970. Concentrations of soil nutrients before and after fire. Canadian Journal of Soil Science 50:17-29.

Soil Survey Staff. 2003. Official soil series descriptions.

Soil Survey Staff. 2014. Web Soil Survey. http://websoilsurvey.nrcs.usda.gov/. 
Solaiman, Z. M., D. V. Murphy, and L. K. Abbott. 2012. Biochars influence seed germination and early growth of seedlings. Plant and Soil 353:273-287.

Thom, D., and R. Seidl. 2015. Natural disturbance impacts on ecosystem services and biodiversity in temperate and boreal forests. Biological Reviews.

Thome, D. M., C. J. Zabel, and L. V Diller. 1999. Forest stand characteristics and reproduction of northern spotted owls in north-coastal California forests. Journal of Wildlife Management 63:44-59.

Tingley, M. W., D. A. Orwig, R. Field, G. Motzkin, M. W. Tingley, D. A. Orwigl, R. Field, and G. Motzkin. 2002. Avian response to removal of a forest dominant: consequences of hemlock woolly adelgid infestations. Journal of Biogeography 29:1505-1516.

Tomkins, I., J. Kellas, K. Tolhurst, and D. Oswin. 1991. Effects of fire intensity on soil chemistry in a eucalypt forest. Australian Journal of Soil Research 29:25-47.

Trabaud, L. 1991. Fire regimes and phytomass growth dynamics in a Quercus coccifera garrigue. Journal of Vegetation Science 2:307-314.

Trant, A. J., W. Nijland, K. M. Hoffman, D. L. Mathews, D. McLaren, T. A. Nelson, and B. M. Starzomski. 2016. Intertidal resource use over millennia enhances forest productivity. Nature Communications 7:12491.

United State Forest Service. 1986. Fire management activity review : 1985 fire season.

Urbieta, I. R., L. V Garcia, M. A. Zavala, and T. Maranón. 2011. Mediterranean pine and oak distribution in southern Spain: is there a mismatch between regeneration and adult distribution? Journal of Vegetation Science 22:18-31.

USDA. 1988. Land resource management plan, Los Padres National Forest. Goleta, 


\section{California, USA.}

Vacchiano, G., M. Lonati, R. Berretti, and R. Motta. 2013. Drivers of Pinus sylvestris L. regeneration following small, high-severity fire in a dry, inner-alpine valley. Plant Biosystems 149:354-363.

Vacchiano, G., S. Stanchi, G. Marinari, D. Ascoli, E. Zanini, and R. Motta. 2014. Fire severity, residuals and soil legacies affect regeneration of Scots pine in the Southern Alps. The Science of the Total Environment 472:778-88.

Vance, E. D., and G. S. Henderson. 1984. Soil nitrogen availability following long-term burning in an oak-hickory forest. Soil Science Society of America Journal 48:184190.

Walker, B., C. S. Holling, S. R. Carpenter, and A. Kinzig. 2004. Resilience, adaptability and transformability in social-ecological systems. Ecology and Society 9:5.

Wardle, D. A., L. R. Walker, and R. D. Bardgett. 2004. Ecosystem properties and forest decline in contrasting long-term chronosequences. Science 305:509-513.

Waring, K. M., and K. L. O’Hara. 2008. Redwood/tanoak stand development and response to tanoak mortality caused by Phytophthora ramorum. Forest Ecology and Management 255:2650-2658.

Weir, J. M. H., and E. A. Johnson. 1998. Effects of escaped settlement fires and logging on forest composition in the mixedwood boreal forest. Canadian Journal of Forest Research 28:459-467.

Westerling, A. L., B. P. Bryant, H. K. Preisler, T. P. Holmes, H. G. Hidalgo, T. Das, and S. R. Shrestha. 2011. Climate change and growth scenarios for California wildfire. Climatic Change 109:445-463. 
Westerling, A. L., H. G. Hidalgo, D. R. Cayan, and T. W. Swetnam. 2006. Warming and earlier spring increase western U.S. forest wildfire activity. Science 313:940-3.

Western Regional Climate Center. 2016a. Big Sur California. http://raws.dri.edu/cgibin/rawMAIN.pl?caCBSR.

Western Regional Climate Center. 2016b. Current observations. http://www.wrcc.dri.edu/weather/index.html.

Will, G. M. 1961. The mineral requirements of radiata pine seedlings. New Zealand Journal of Agricultural Research 4:309-327. 


\section{APPENDICES}

\section{APPENDIX A: METHODS OUTLINE}

\section{Site Selection}

- On-the-ground visits with land managers to discuss disturbance history and identify potential sites

o Select general plot locations using spatial analysis to identify areas with similar elevation, aspect, slope, and coarse soil designations.

- $\quad$ Study areas stratified in ArcGIS 10.2.2 by:

o Vegetation type

o Disturbance history

- Singular fire disturbance

- Compounding fire disturbance

o Redwood vegetation types of varying disturbance history identified.

o Local Environmental Factors

- Aspect

- Slope

- Elevation

- Soils

o Once large areas of with similar site variables (above) identified, two polygons created at each disturbance location.

- $\quad$ Stratified random selection in ArcGIS 10.2.2: 
o 15-meter buffers created in ArcGIS around each site to avoid selection of plot corners along roads, trails, etc. In one case trail contact was unavoidable.

o Plot Selection:

o 2-3 randomly selected grid centers using the ArcGIS Sampling Design Tool (add-on) for site installation. Use Sampling Design Tool to randomly drop sample points with the "Create Point Samples” option

o These points served as the NW plot corners for two 0.25 ha sampling plots. $3^{\text {rd }}$ point can be used as a backup in case one doesn't work out.

\section{Detailed Sampling Protocols}

- We established two 0.25 ha (50m x 50m) plots per sampling area

- Each plot will consist of 250.01 ha (10m x 10m) subplots

- Subplots were numbered in the following manner for consistency

o Subplot 1 always falls at the NW corner of the plot and then from 1-25 so that the $25^{\text {th }}$ subplot fell in the SE corner.

- $\quad$ Plot layout

o One plot corner randomly selected using ArcGIS (usually NW)

o Specific corner (NW, NE, SW, SE) determined on the ground and dependent upon proximity to roads/trails/etc. that may bisect plot.

o Plot corner locations surveyed using Trimble GPS unit using 30 point collections for each GPS location stored. Aim for $<1$ m accuracy.

o Plots broken down into 25 0.01ha subplots for ease of mapping.

o First steps: 
- Set in rebar at four corners.

- Flag out $10 \mathrm{~m}$ x $10 \mathrm{~m}$ subplot centers with fluorescent fiber markers and a piece of flagging giving subplot number.

- Found in 2016 season that it was easiest to map all stems from subplot centers, using these as permanent reference points (GPS coord taken at each subplot center).

- Re-check 0.25 ha plot boundaries while mapping from subplot centers to ensure accuracy.

- Stem mapping

o All trees/regeneration falling with the plot were mapped, measured, and tagged.

o When clumps of sprouts are encountered, all individuals were counted, and $10 \%$ will be tagged and measured for baseline diameter.

o Definitions (USFS FIA Program):

- Mature tree $>12.5 \mathrm{~cm}$

- Sapling $=2.5-12.5 \mathrm{~cm}$ (and $>1.37 \mathrm{~m}$ height).

- Seedling or sprout $<2.5 \mathrm{~cm}$

o Reference points were established throughout the 0.25 ha plot for surveying

- High accuracy GPS coordinates will be taken at all plot corners

- Found that if subplot centers could be plotted ahead of time in ArcGIS if 0.25 ha plot corners were known, allowing us to use the Trimble in the field to find subplot centers rather than measuring out. Needed to ensure proper sampling within main plot boundaries, though. 
- All trees within view were mapped with a logger's tape and a handheld compass to determine azimuth.

- Additional reference points were added as crews moved throughout the stand and mapped each tree falling within the plot boundaries.

- Reference points in the first field season were mature trees identified as needed; in the second season subplot centers were used exclusively.

- Reference points, distances, and azimuths were processed in $\mathrm{R}$ and used to create tree-level coordinates and stand visualizations.

o As one crew member tagged, mapped, and measured each tree, a second crew member recorded tree-specific data for the associated tag, including:

- Species, status (l/d), life stage (seedling/sprout/sapling/mature),diameter, crown class (D, C, I, S), damage

- Damage notes included fire marks (their height relative to trunk of tree), sudden oak death symptoms, obvious insect/fungal pathogens, any goose pens from burns

- Seedlings and Sprouts

- Note seedling (SE) or sprout (SP) for baby trees

- $\quad$ Seedlings $=$ individuals $>1 \mathrm{~m}$ from sprouts and/or trees

- Noted medium of establishment if not on ground (e.g., CWD)

o The following data were collected on a subset of trees:

- Number of trees (for sprouts ONLY - all others just 1 tree/data row)

- Decay Class (snags only) 


\section{o Details on Tagging Trees \& Taking DBH}

- $\mathrm{DBH}$

- Tree diameters were taken at a consistent point on the tree (50 cm below tag - one hammer length). Standardization was a concern the first season, so we marked a PVC pole with the appropriate heights and used this as a reference in the field.

- Diameters were always taken on the uphill side of the tree, with the tape/caliper held level.

- Calipers were used for saplings and regeneration.

- Tagging

- Always tag AWAY from a road/trail to avoid vandalism/theft.

- Tagging occurred counterclockwise within subplots, starting where the recorder was standing at the reference point and looping toward the next subplot.

- Fisheye photos

o Pictures should be taken on overcast days or (if necessary) when the sun is low in the sky. Any sun exposure in the image will overexpose pieces of canopy and render that part of the image useless for processing.

o We typically took two fisheye photos at the center of each subplot being included in the subset for modeling. The second was for backup.

o Recorded the image number(s) corresponding to each subplot for later record. 
o Set up tripod so that the lens is exactly one-meter height off the ground.

o Take all pictures so top of image is facing north (geographic $\mathrm{N}$ at top).

o Level camera in two directions - it is important that the camera is level.

o Use manual control for taking picture. Can compensate for brightness by adjusting film speed and/or f-stop (check camera manual).

o Recorded date and time when photo was taken.

- $\quad$ Seed Rain Traps (See Figure A.23.)

o Materials used per trap:

- Six meters of 0.5 inch diameter PVC pipe

- Cut into four 80-cm legs and four 70.7-cm sides

- Four PVC elbows/tees - forms corners and points of attachment

- Two meters of 0.25-inch diameter rebar

- Drove $0.5 \mathrm{~m}$ into ground to hold two legs in place

- $\quad$ One four foot by four foot (1.3 m by $1.3 \mathrm{~m})$ piece of window screen material (1-mm plastic coated fiberglass window screen)

- Zipties to fix PVC screen to frame

o Five $0.5 \mathrm{~m}^{2}$ PVC frames were randomly placed within each plot.

- Traps were squares with window screen zip-tied across the top to create a net. We allowed the netting to sag a bit to hold onto seed catch better.

- Two legs of each trap were mounted on lengths of rebar to ensure that traps don’t move. 
o We planned to empty these monthly but in reality only emptied them once or twice during the season.

- Redwood cones were placed in a paper bag and labeled by location for use in greenhouse study

- Soils

o Soil samples were collected from ten random locations (the 0.01 ha subplots used for modeling data) within each 0.25 ha plot.

- Samples were collected using a trowel down to $10 \mathrm{~cm}$ depth. At each 0.25 ha plot we checked to make sure that the A horizon was deeper than $10 \mathrm{~cm}$ before sampling to this depth, as the A horizon was our target sampling depth.

- We walked the diagonals of each subplot, collecting 6 small soil samples to $\sim 10 \mathrm{~cm}$ depth with trowels along each diagonal and using them to make a composite full-subplot sample in a 5gallon bucket. We brought back 0.5-1.0 gal of soil from each subplot.

- Soil samples were air dried for 2+ days prior to analysis and then sieved to remove rock fragments $>2 \mathrm{~mm}$.

- Samples were sent to A\&L Labs in Modesto, CA for analysis using the S1BN package and extra $\mathrm{NH}_{4}{ }^{+}$measurement. All tests included: organic matter, estimated nitrogen release, phosphorus (Weak Bray and sodium bicarbonate-P), 
extractable potassium, magnesium, calcium, sodium, hydrogen, sulfate-S, pH, cation exchange capacity and percent cation saturation (computed).

- We ran a total C \& N analysis with Craig Stubler using the NRES Department's CHN analyzer during the summer of 2016. This was done for all 80 samples using the same soil collected for A\&L Labs.

o We collected bulk density samples from each of the subplots used for modeling data between November 2015 and March 2016. These were collected with a slide hammer setup provided by Craig Stubler.

- Two bulk density samples were collected at each subplot $~ 1 \mathrm{~m}$ apart.

- Samples were oven dried for 48 hours and then bulk density was calculated, including a correction for rock fragment volume and mass.

\section{Greenhouse methods}

- Soil was collected from just outside of a 0.25 ha plot in each burn history (only one sample per burn history) and seed from seed traps was used with this soil to run a greenhouse experiment.

- We collected enough soil from each burn history to fill $32655 \mathrm{~cm}^{3}$ seedling pots from Stuewe \& Sons. In the field the soil was run through a sieve with large openings to remove the largest rock fragments.

o In total we used 128 seedling pots: we ran a full factorial experiment with 4 seed sources $x 4$ soil sources $x 8$ replicates of each source. 
- Soil was air dried in a greenhouse until no longer moist. Pots and their holders were cleaned with a $10 \%$ bleach solution and rinsed.

- We glued redwood seeds to toothpicks (lightly; Figure A.1.) so that we could keep track of seedling germination in each pot and ensure that germinants weren’t recruits from the soil we collected. Two seeds were glued to each toothpick, and ten toothpicks planted in each pot.

o We lined up 15 toothpicks per row in three rows on sheets of paper, taped them down, and then glued seeds to them one by one. Seeds were lightly deposited with forceps.

- Pots were lined with extra window mesh from the seed traps, filled $1 / 3$ with rinsed pea gravel, then filled just short of final volume with soil (unsieved).

o Toothpicks were placed before fully full, then once all 10 were in the pot they were covered with soil to the appropriate depth to prevent snapping off seeds while pushing into the soil.

- Water was provided to pots as needed to keep the soil just below the surface moist.

- Pots were rotated once during the experiment, which ran for three months.

o The largest seedling in each pot was allowed to live if multiple sprouted.

- At the end of three months all seedlings were measured for above and belowground height/length, air-dried in the greenhouse, and then measured for above and belowground mass. 
Table A.1. Soil classifications determined by profile description during June 2016. I dug a soil pit and wrote a description for each 0.25 ha plot in our study. (Plot numbers correspond to random point numbers used to determine each 0.25 ha plot location and do not reflect that actual number of plots at each burn history.) Detailed classification sheets are attached as Figures A.7 - A.22.

\begin{tabular}{lll}
\hline Location & Plot & Classification \\
\hline \multirow{2}{*}{ Pfeiffer Big Sur } & Buzzard's Roost \#1 & Clayey-skeletal, mesic Typic Argixeroll \\
State Park & Buzzard's Roost \#2 & Clayey-skeletal, mesic Typic Haploxeroll \\
& Post Creek \#1 & Clayey-skeletal, mesic Typic Argixeroll \\
& Post Creek \#2 & Fine-loamy, mesic Lithic Argixeroll \\
\hline \multirow{3}{*}{ Big Creek Reserve } & Whale Point \#1 & Loamy-skeletal, mesic Typic Haploxerept \\
& Whale Point \#3 & Clayey-skeletal, mesic Typic Argixeroll \\
& Interpretive Trail \#0 & Loamy-skeletal, mesic Typic Haploxerolls \\
& Interpretive Trail \#2 & Loamy-skeletal, mesic Typic Haploxerolls \\
\hline
\end{tabular}

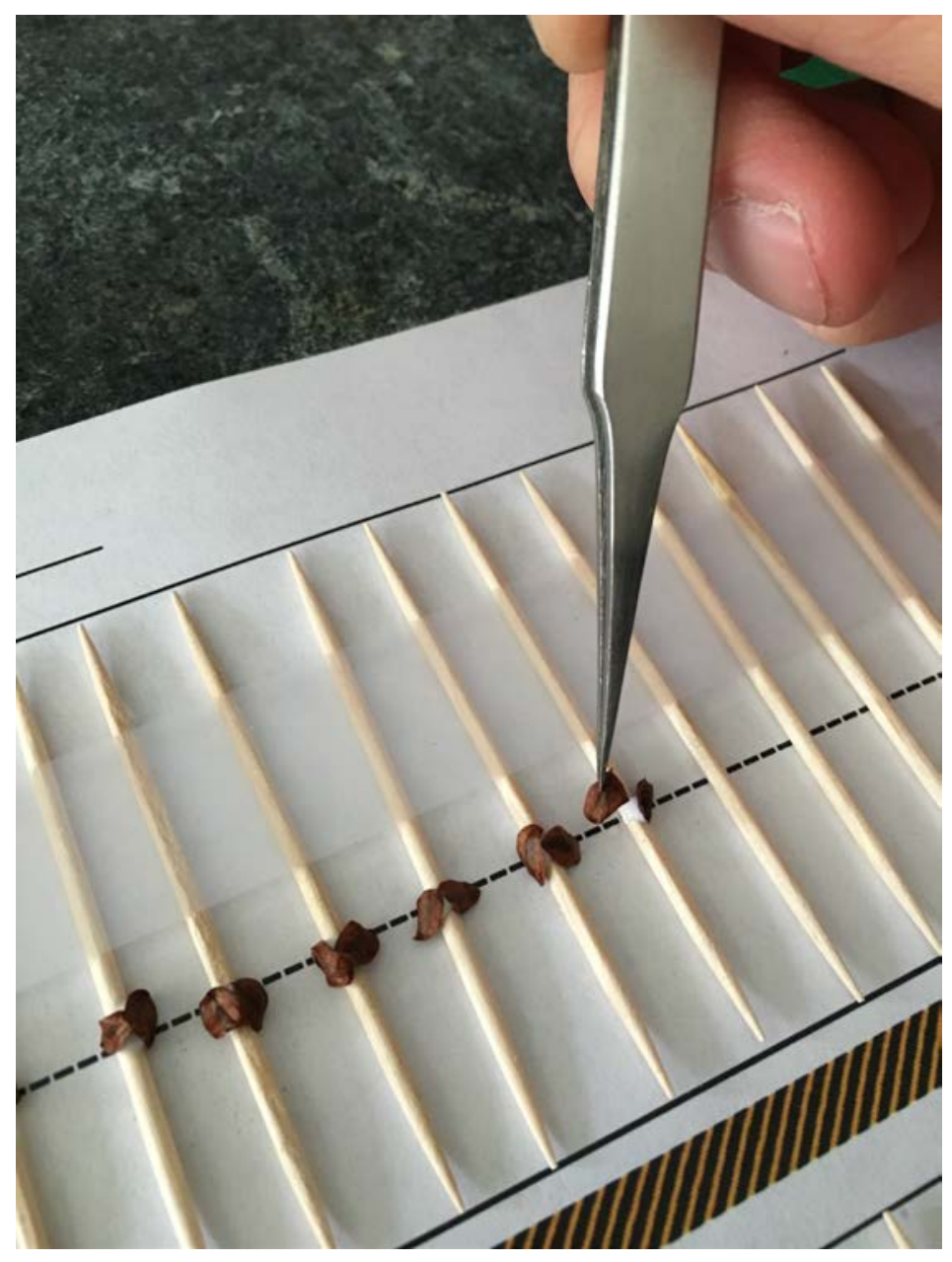

Figure A.1. Gluing redwood seeds to toothpicks. Glue was applied to each toothpick and seeds were deposited lightly with forceps. Two seeds were glued to each toothpick and ten toothpicks were deposited in each seedling tube at planting. 

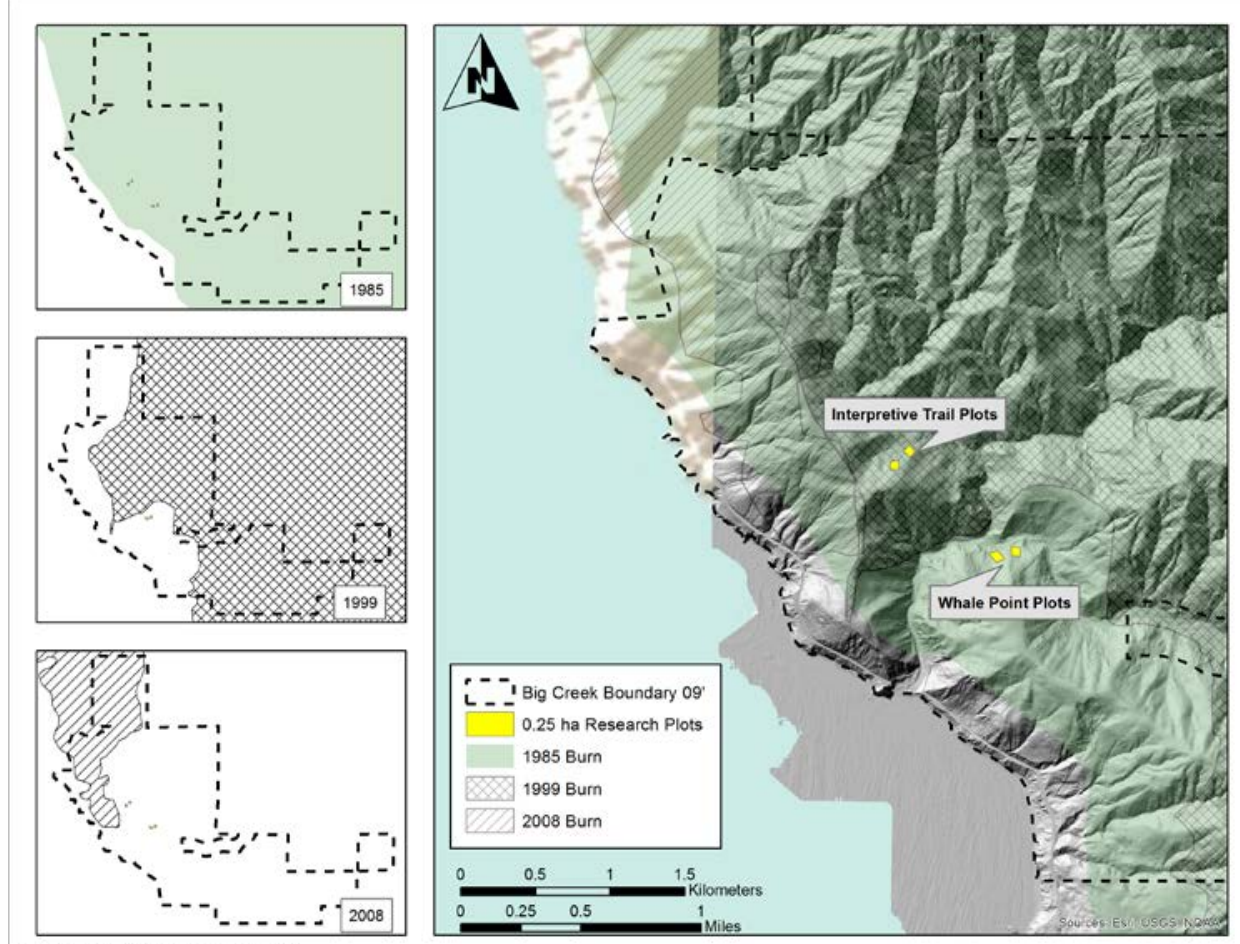

Figure A.2. Map of 0.25 ha research plot locations relative to fires at Big Creek

Reserve properties since 1985. Data from Department of Forestry and Fire Protection
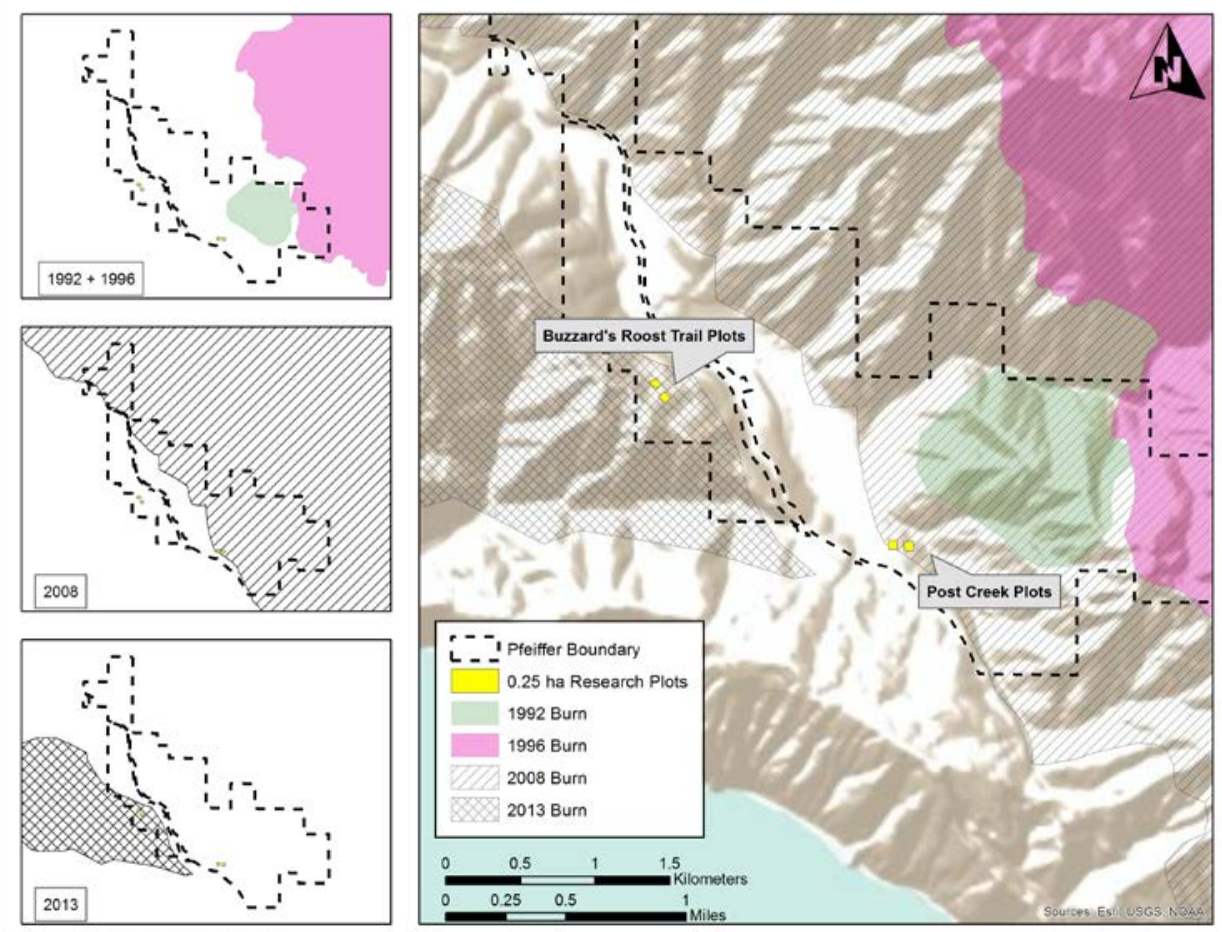

Figure A.3. Map of 0.25 ha research plot locations relative to fires at Pfeiffer Big Sur State Park since 1985. Data from Department of Forestry and Fire Protection (2015). 


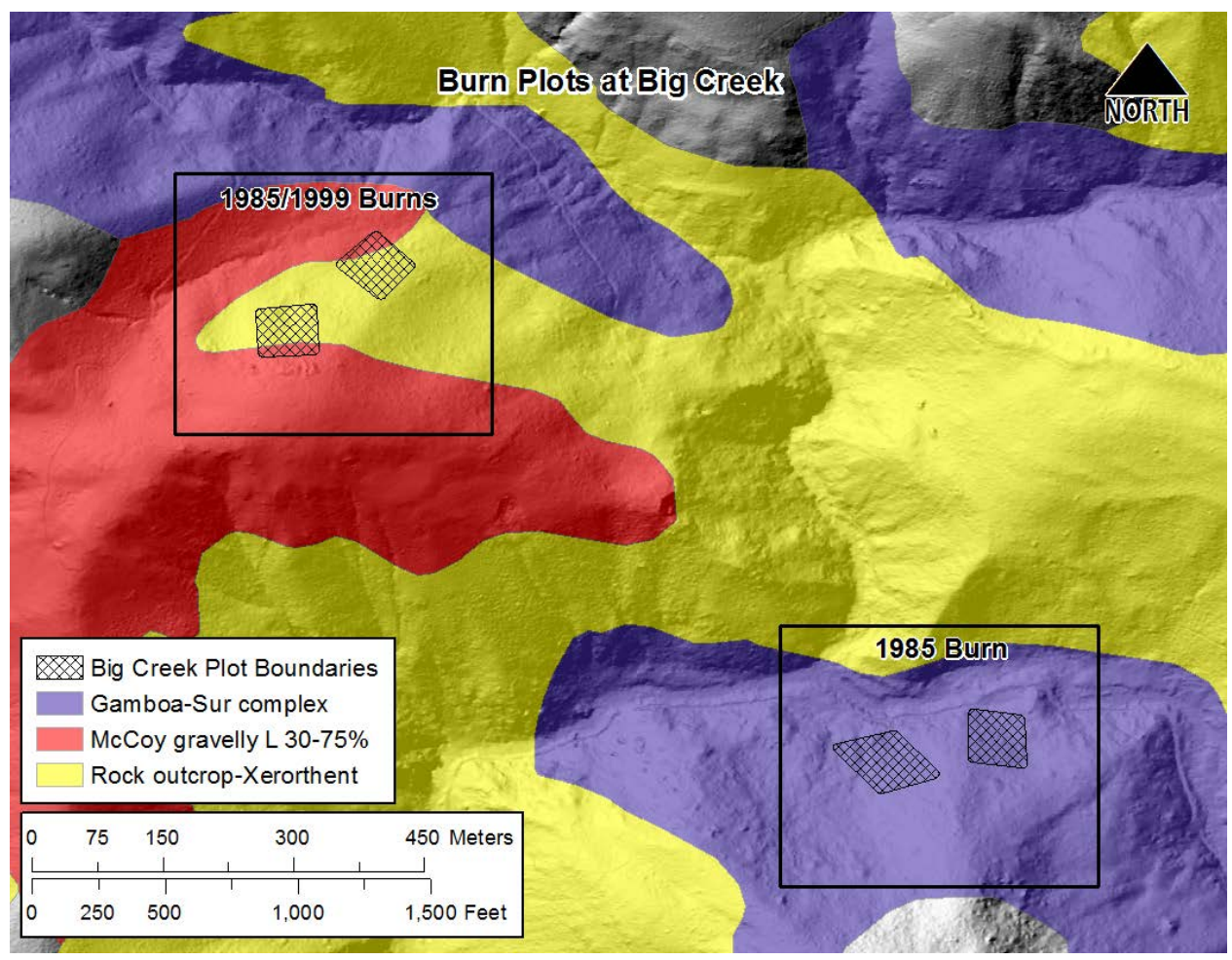

Figure A.4. Soil map units at Big Creek Reserve relative to 0.25 ha plot locations. Data from Soil Survey Staff (2014).

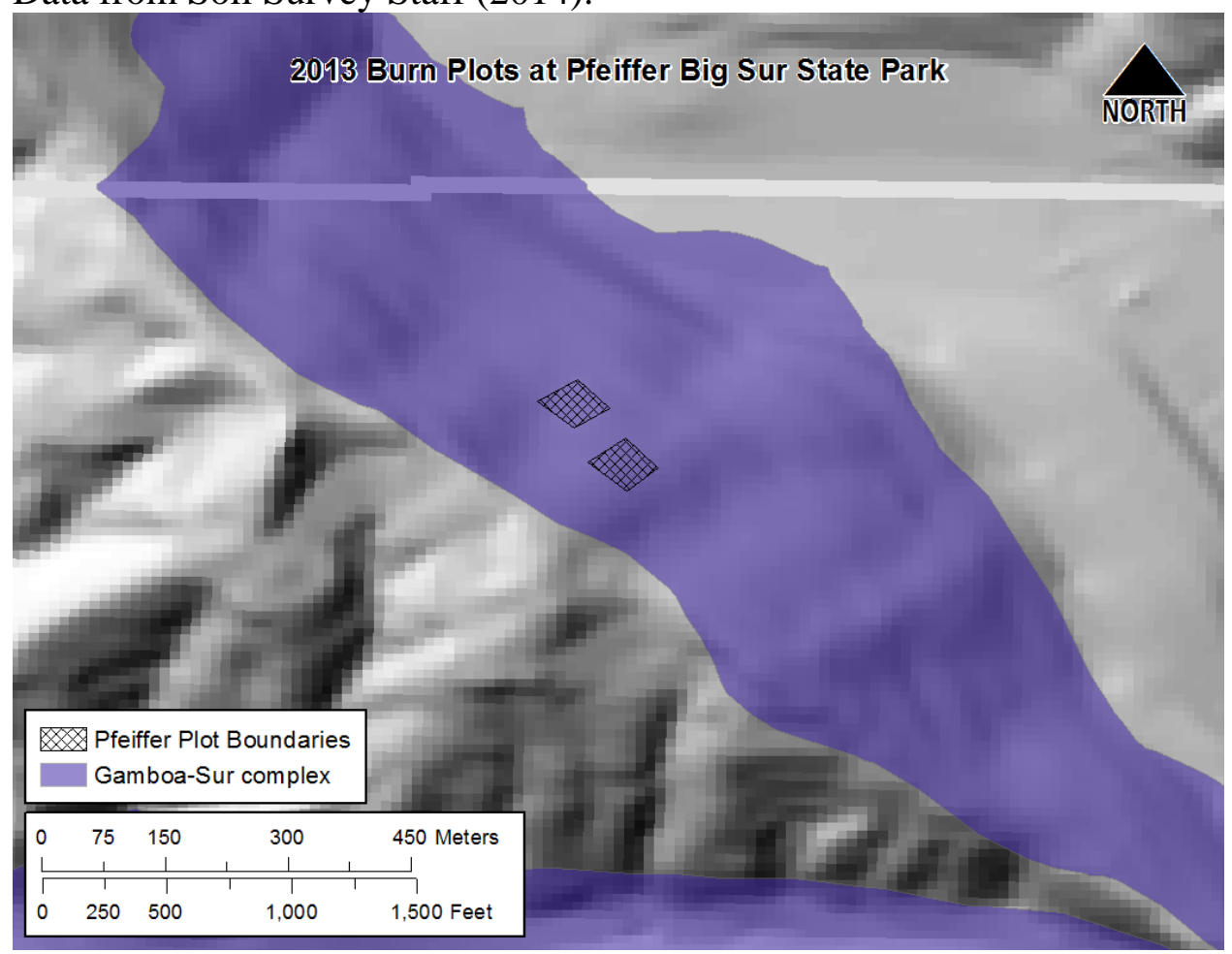

Figure A.5. Soil map units at Pfeiffer Big Sur State Park Buzzard's Roost Trail relative to 0.25 ha plot locations. Data from Soil Survey Staff (2014). 


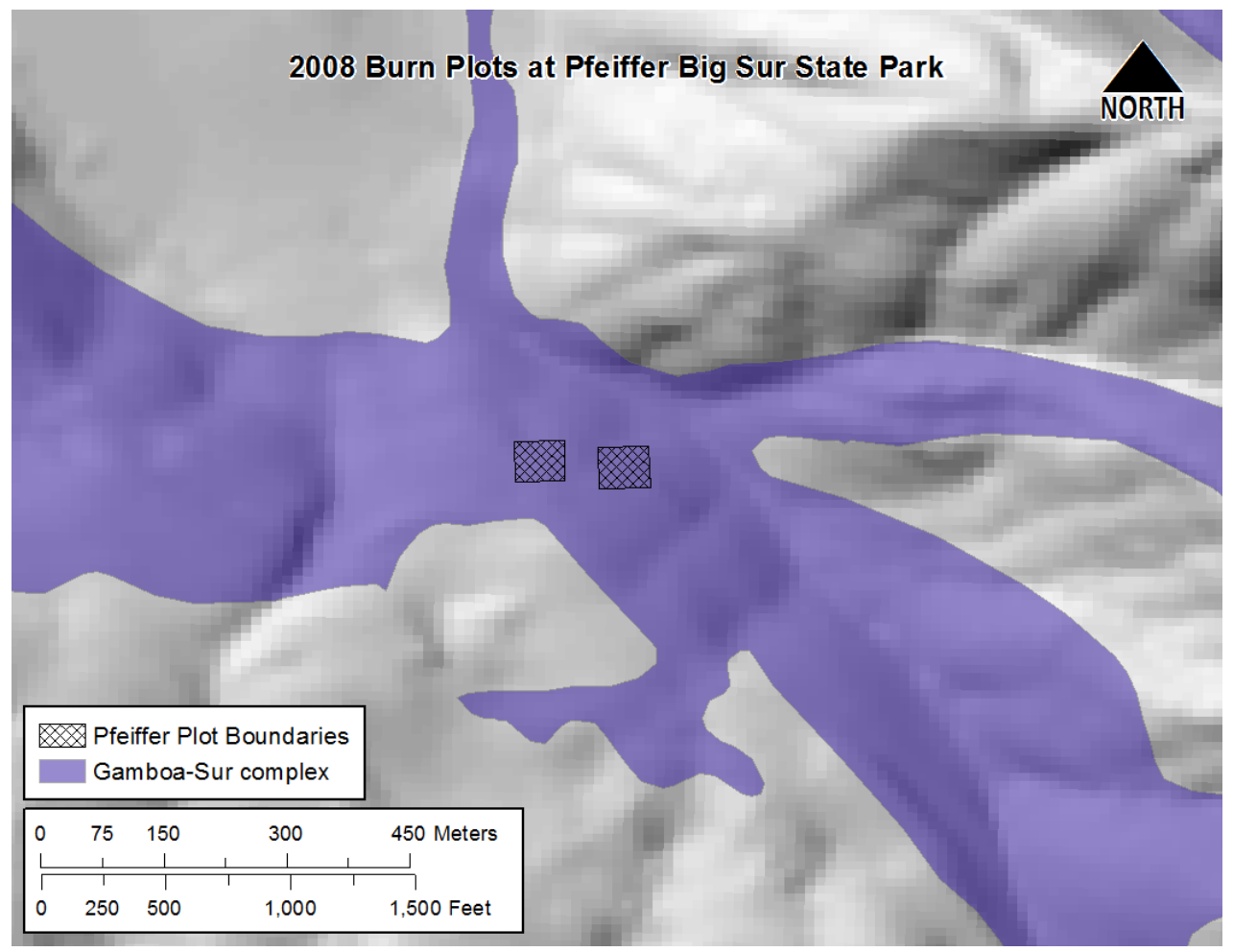

Figure A.6. Soil map units at Pfeiffer Big Sur State Park Post Creek relative to 0.25 ha plot locations. Data from Soil Survey Staff (2014). 


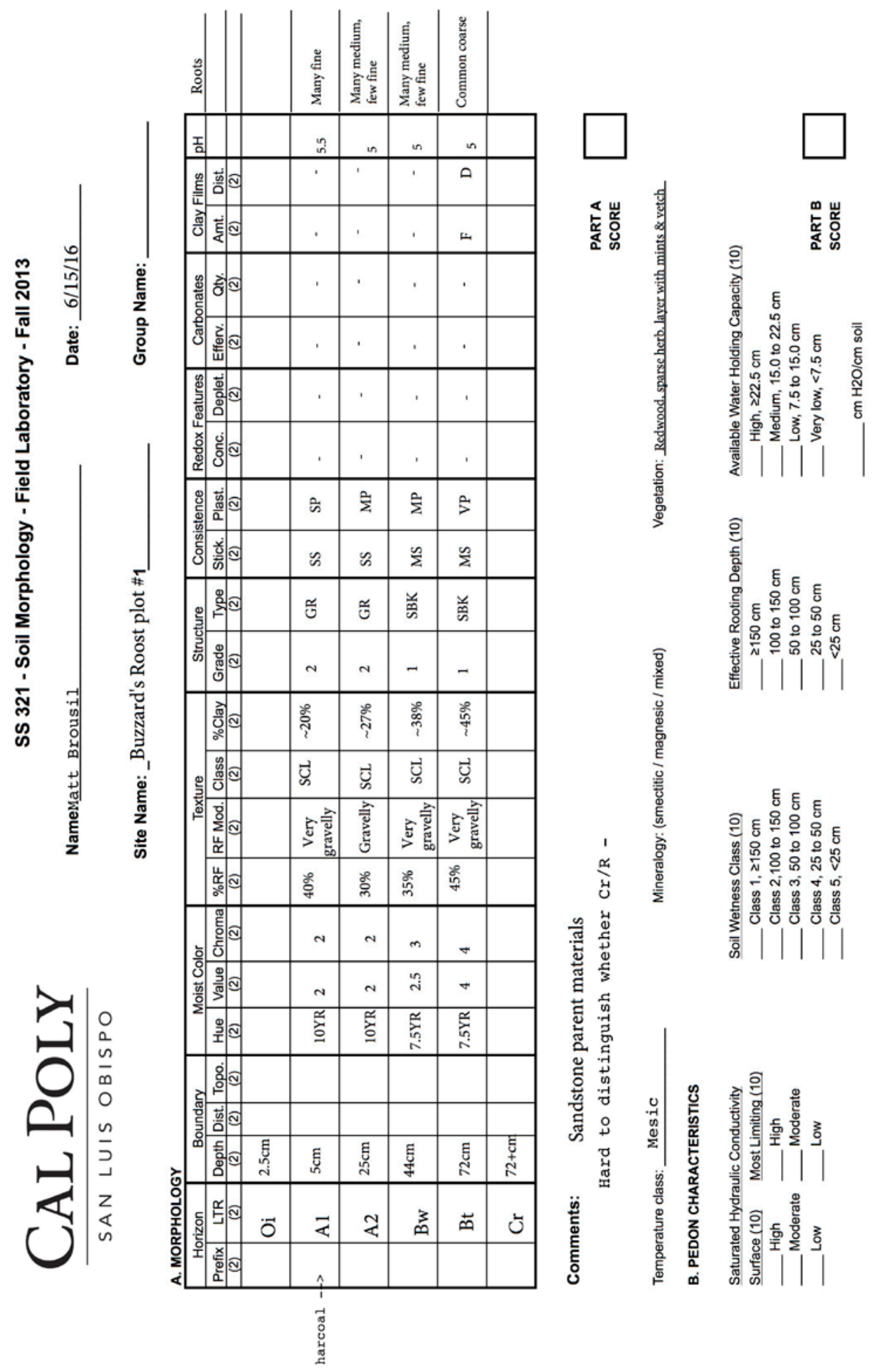

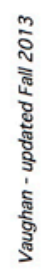

Figure A.7. Front of soil pit classification sheet for Buzzard's Roost \# 1. 


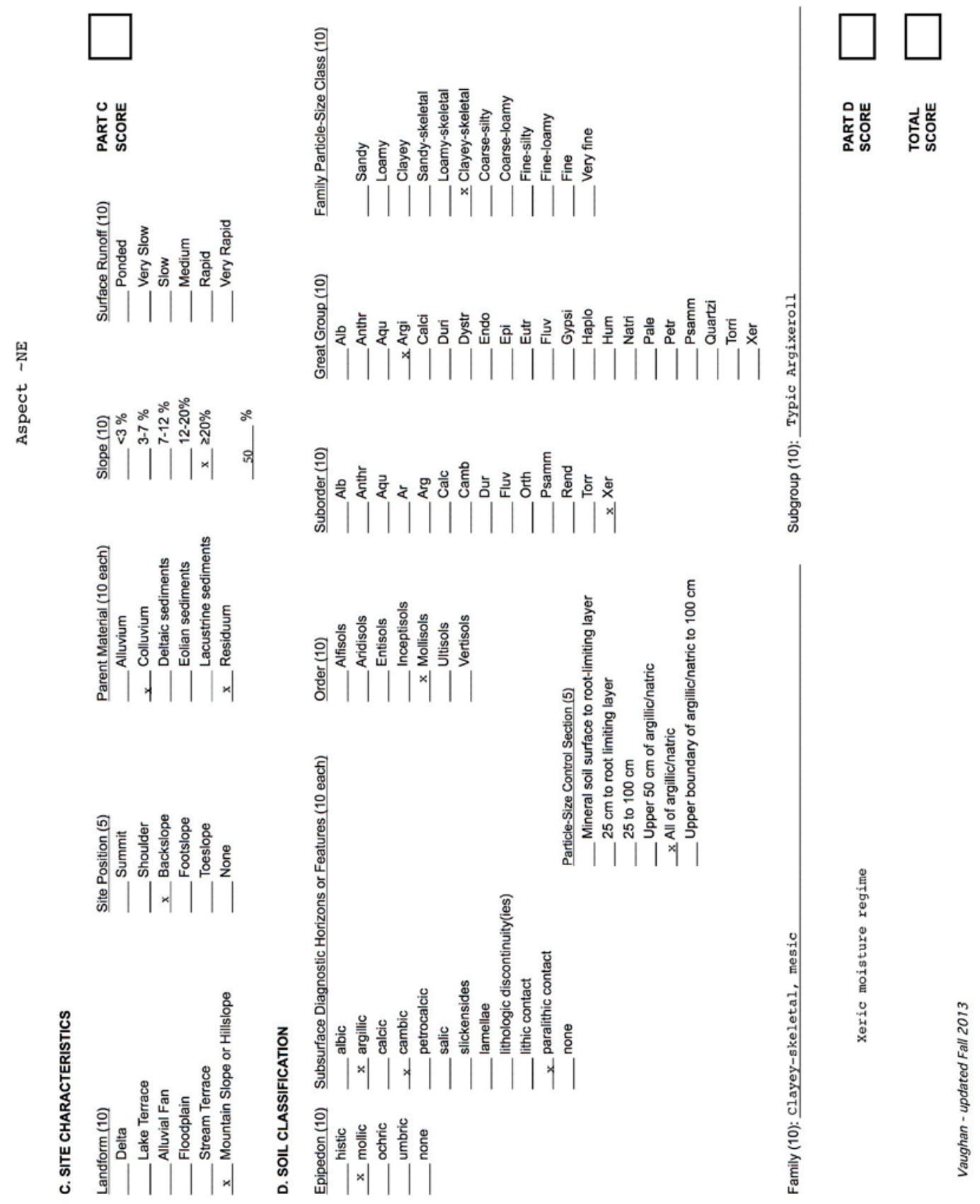

Figure A.8. Back of soil pit classification sheet for Buzzard's Roost \# 1. 

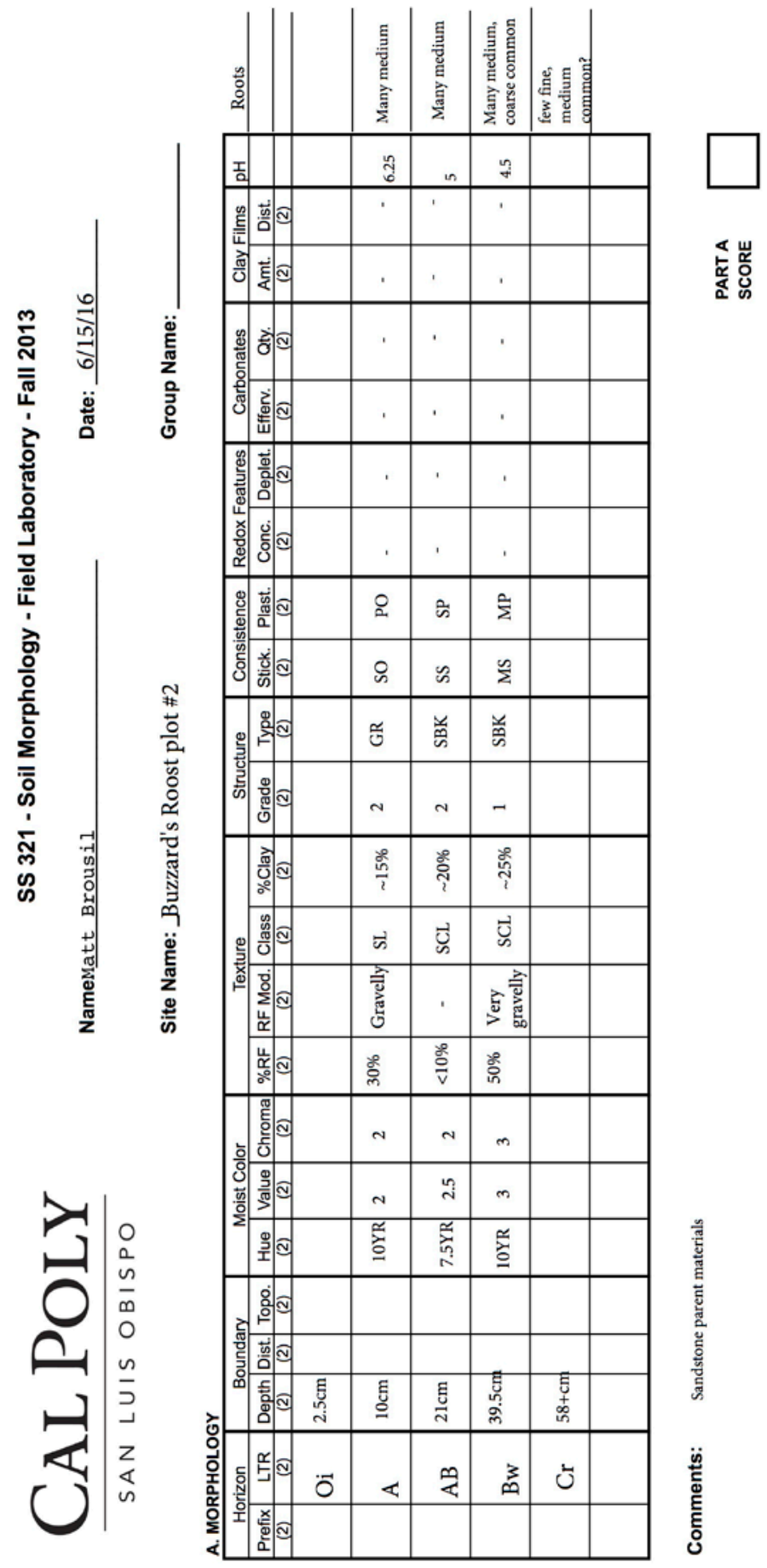

琵
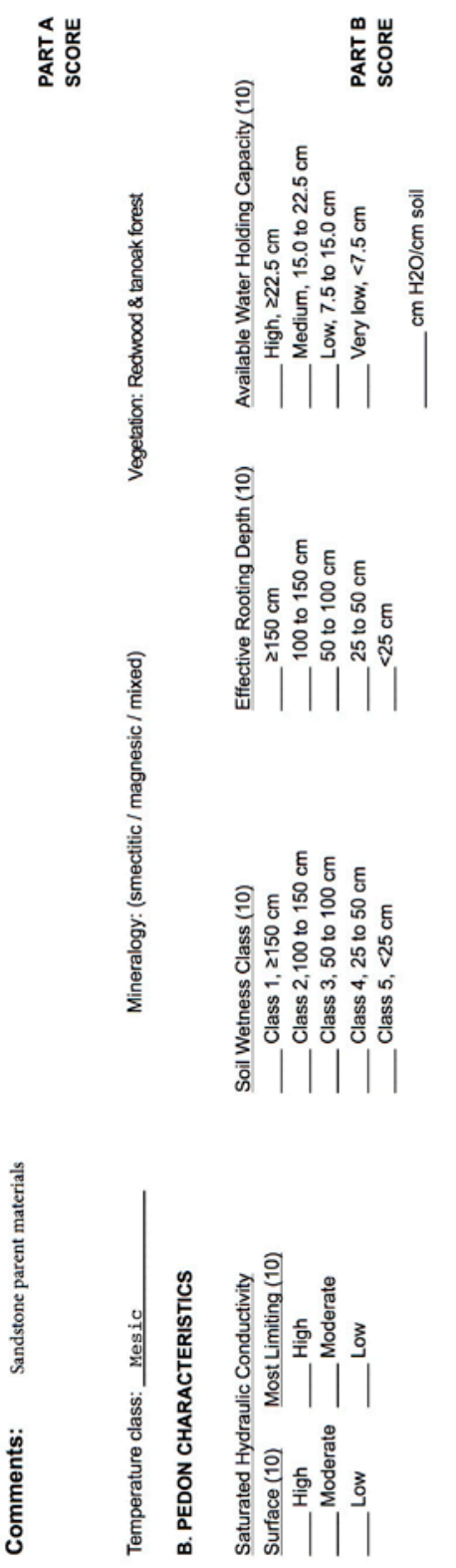

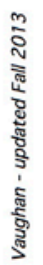

Figure A.9. Front of soil pit classification sheet for Buzzard's Roost \# 2. 


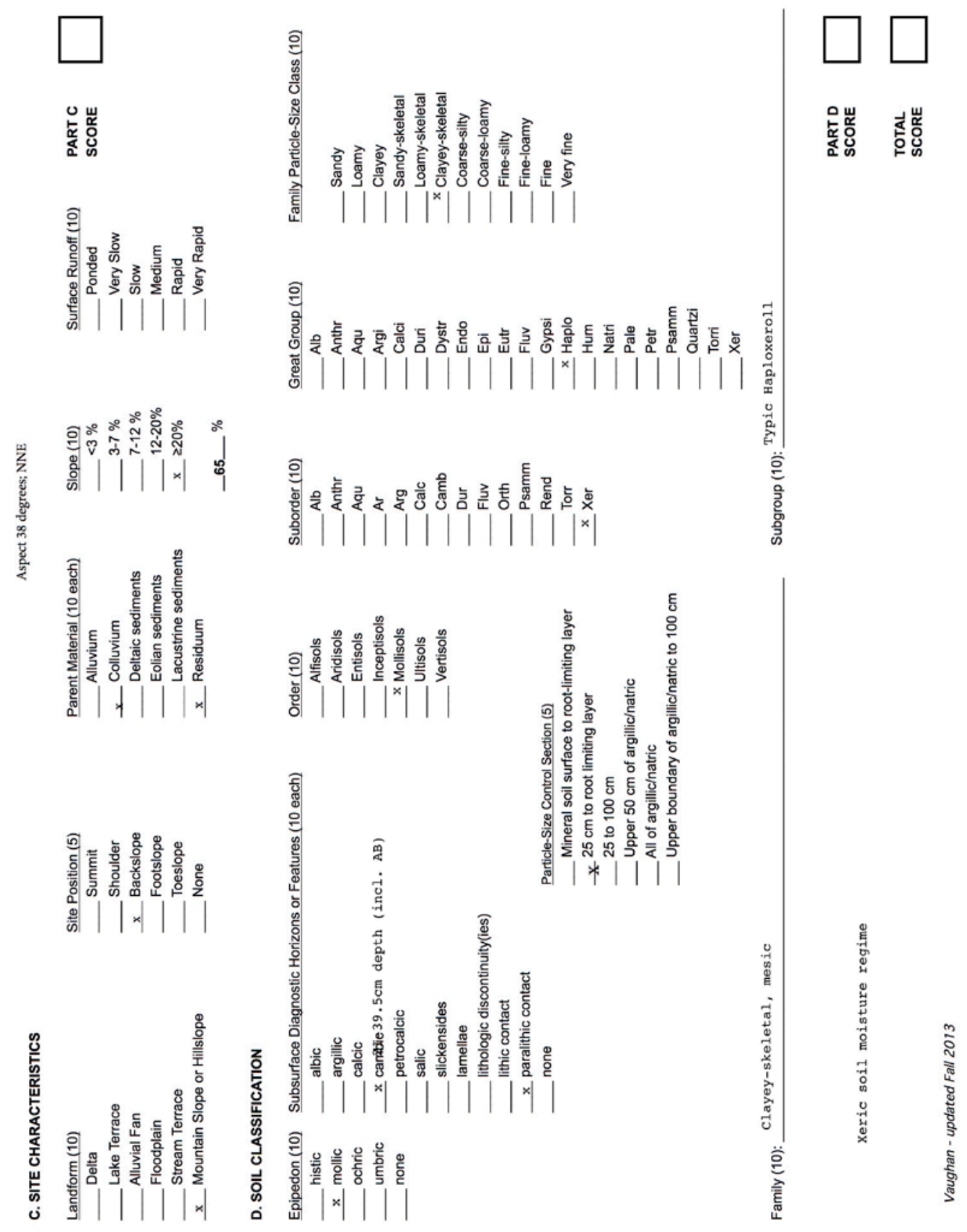

Figure A.10. Back of soil pit classification sheet for Buzzard's Roost \# 2. 


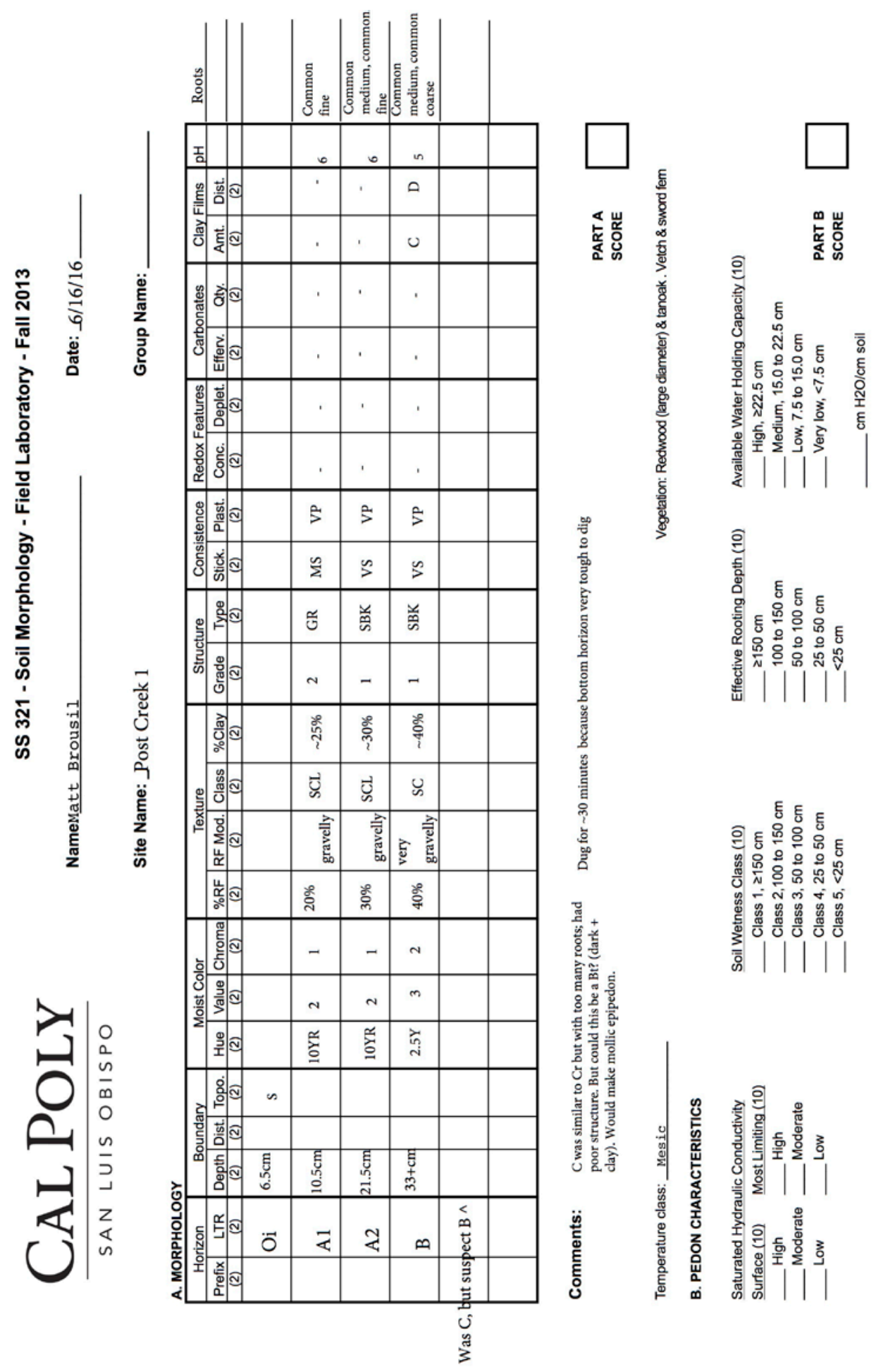

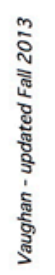

Figure A.11. Front of soil pit classification sheet for Post Creek \# 1. 


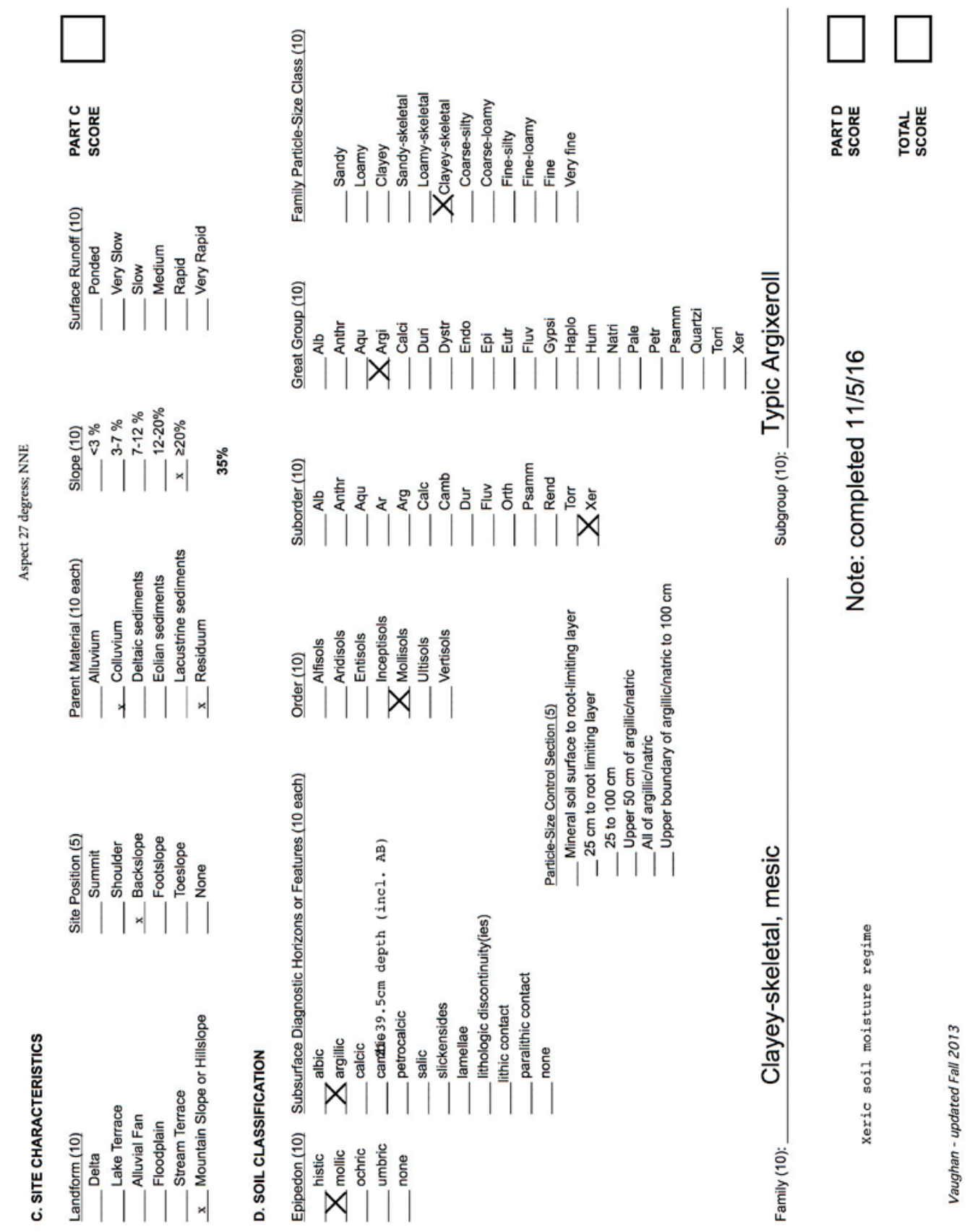

Figure A.12. Back of soil pit classification sheet for Post Creek \# 1. 

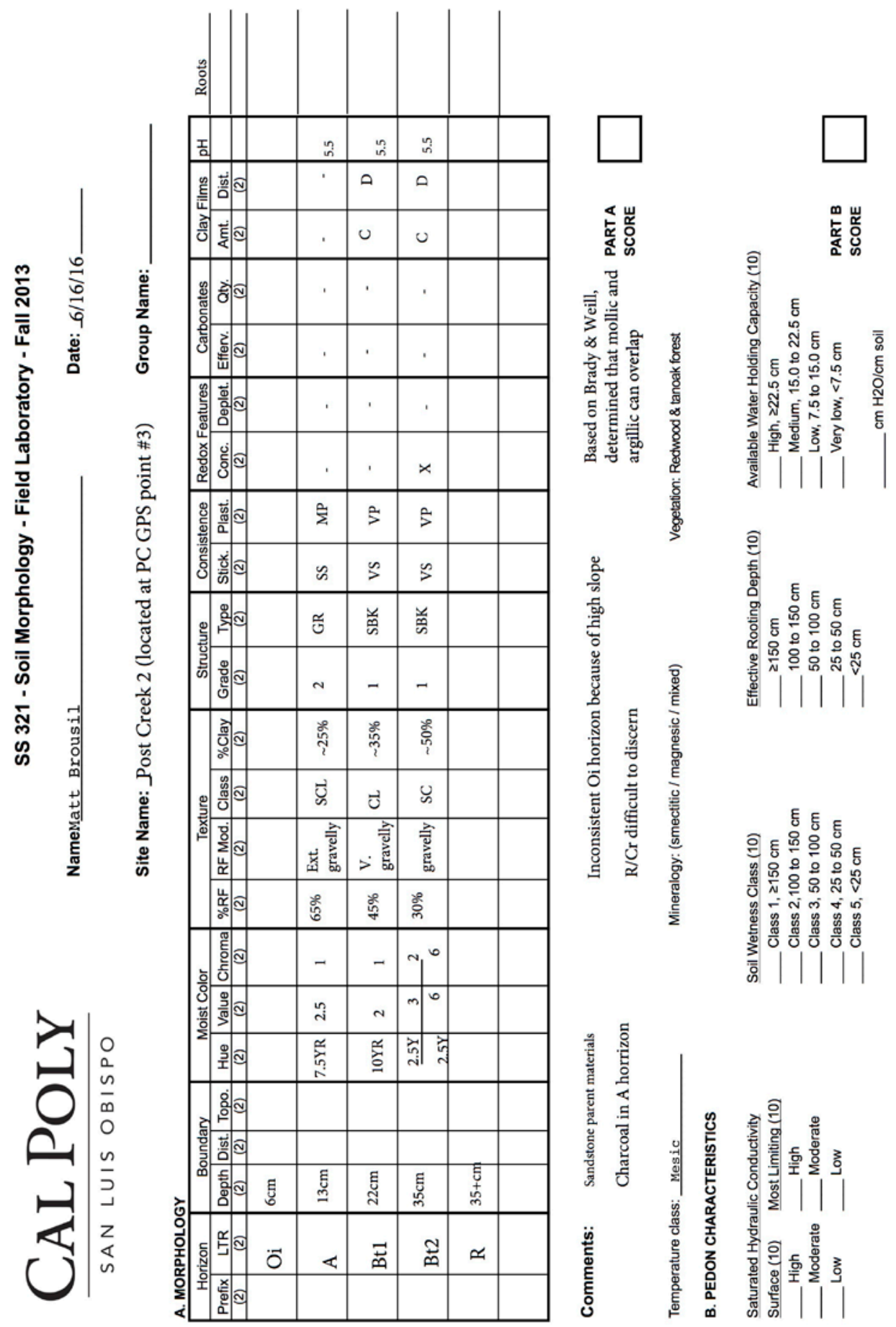

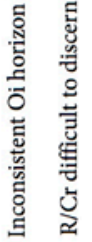

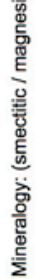
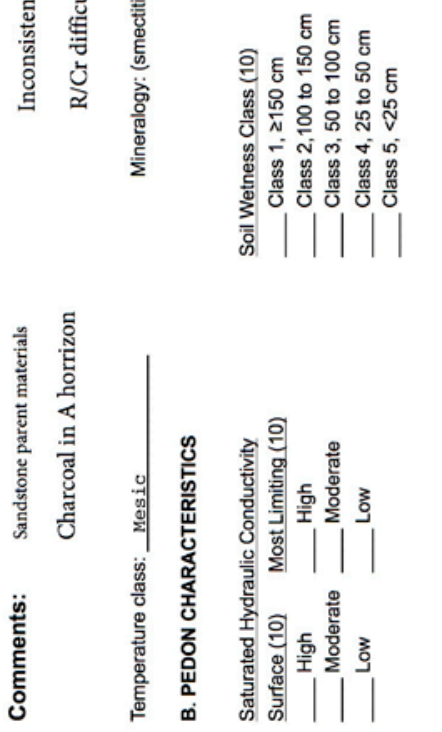

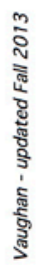

Figure A.13. Front of soil pit classification sheet for Post Creek \# 2. 


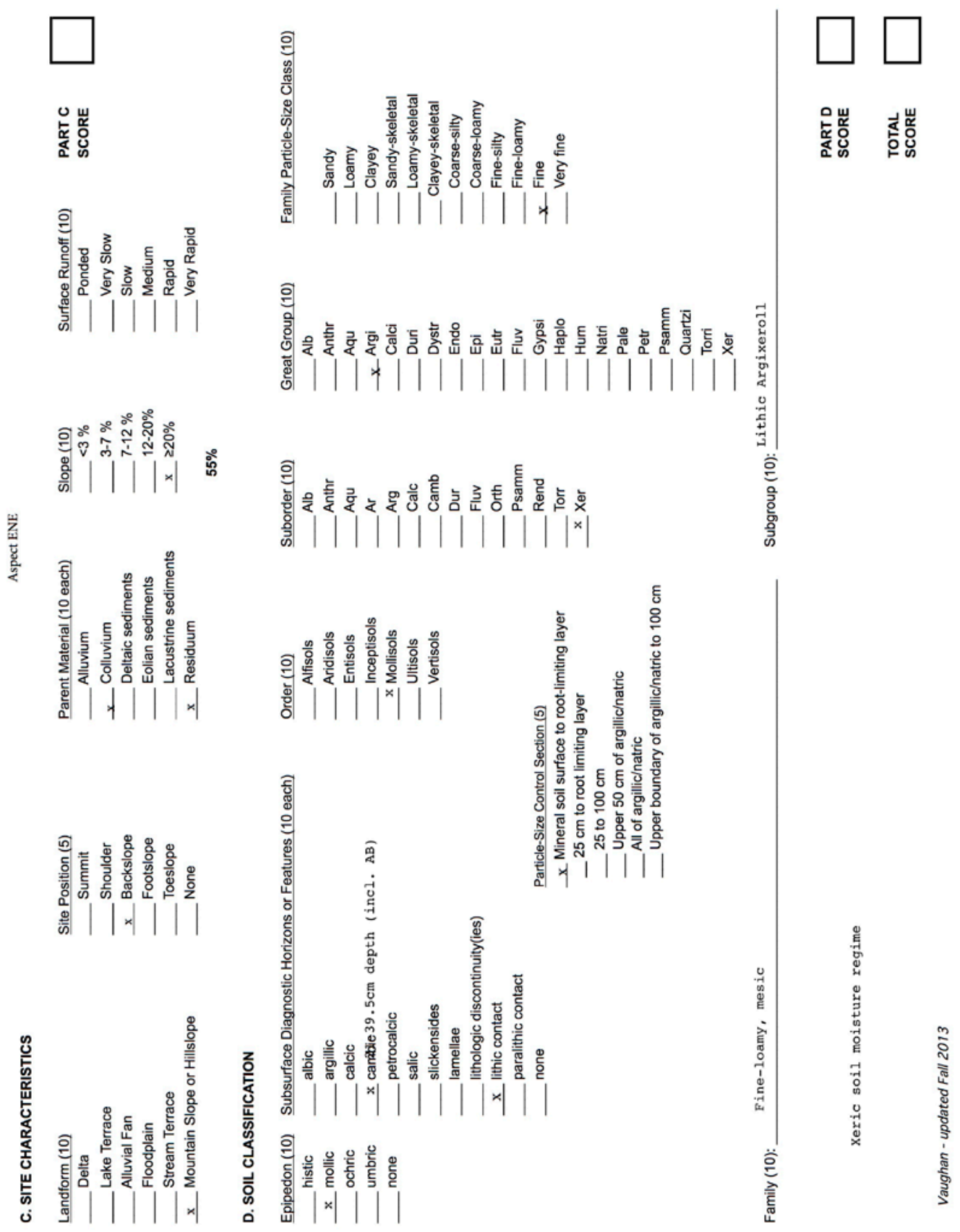

Figure A.14. Back of soil pit classification sheet for Post Creek \# 2. 


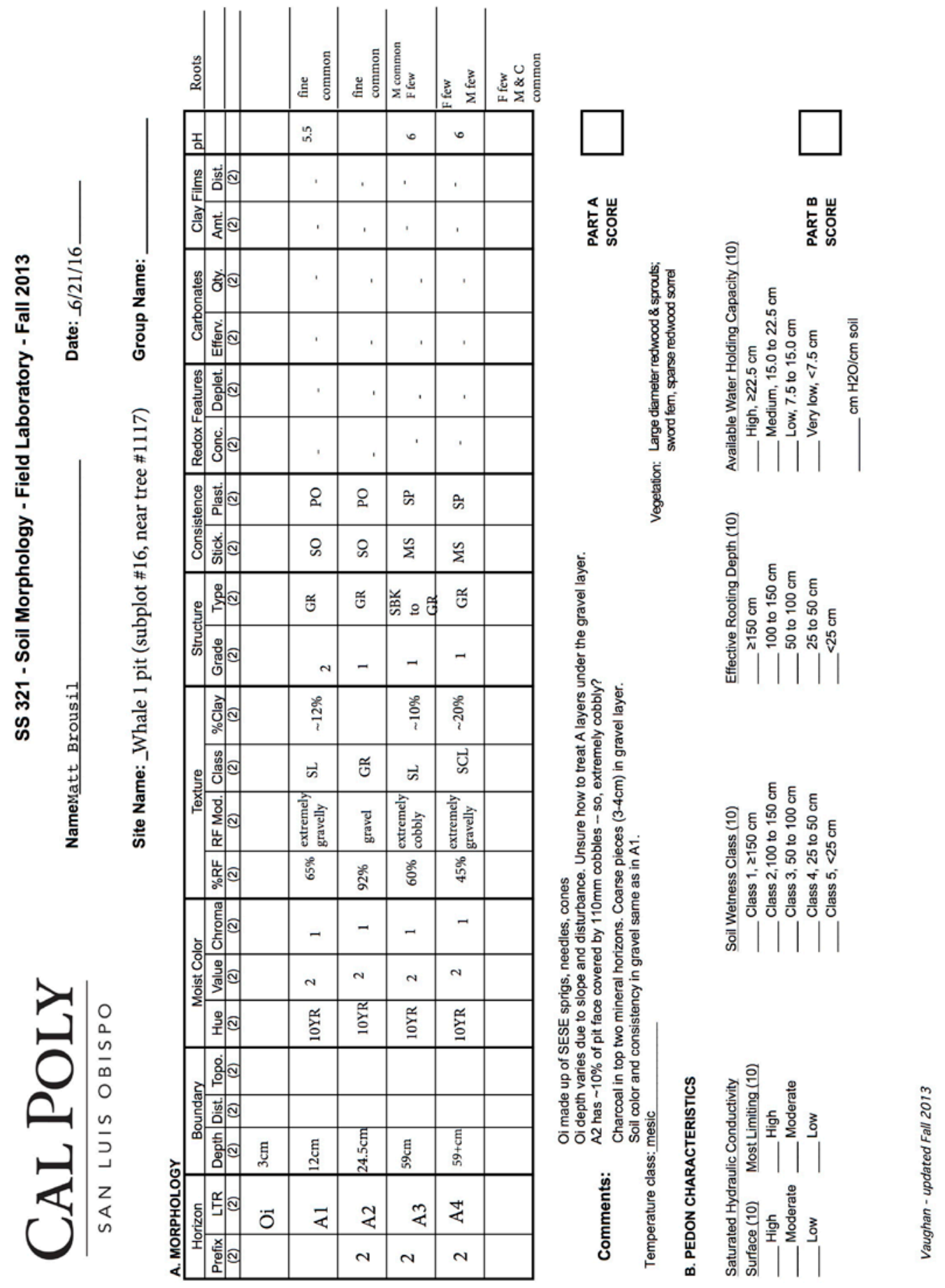

Figure A.15. Front of soil pit classification sheet for Whale Point \# 1. 


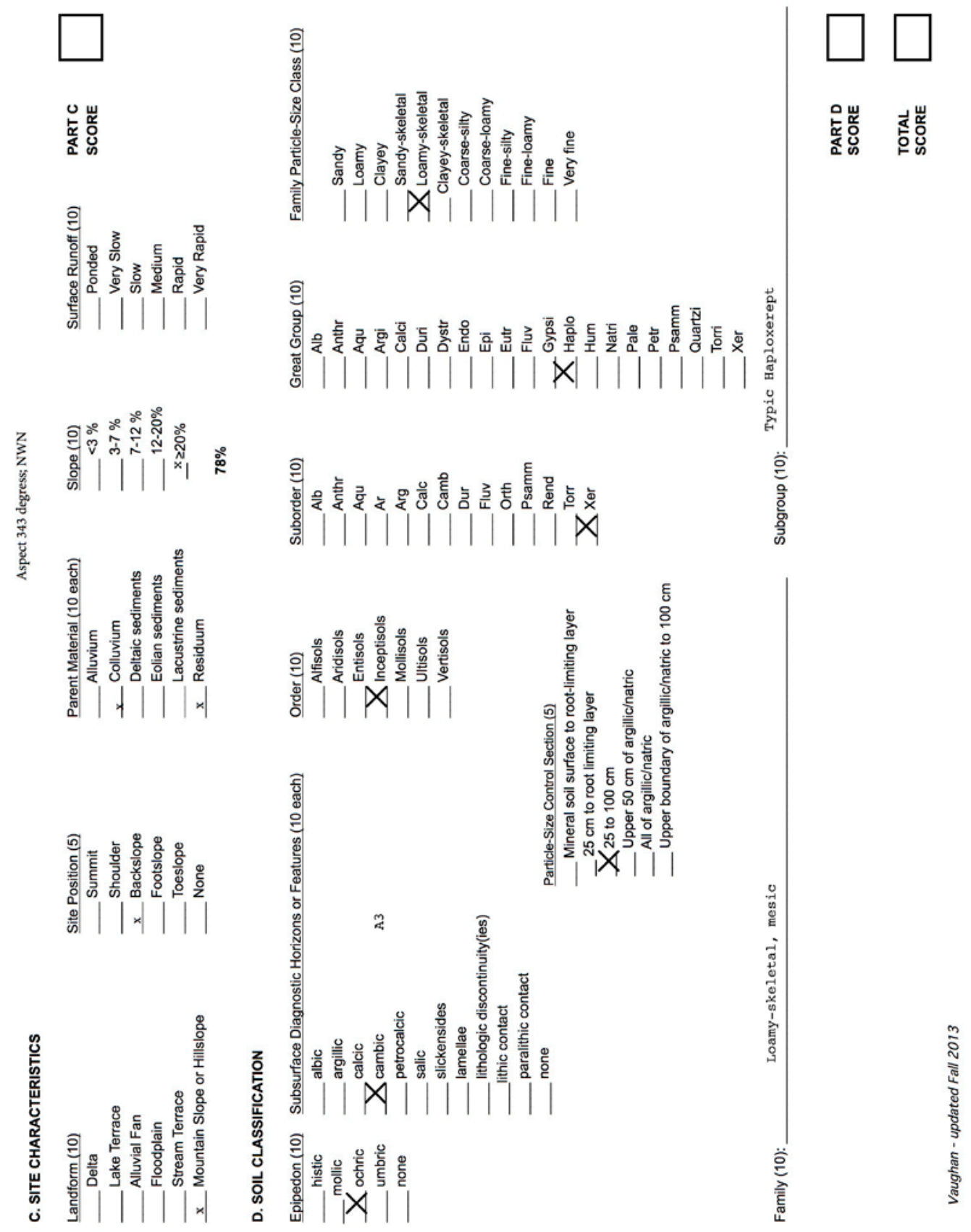

Figure A.16. Back of soil pit classification sheet for Whale Point \# 1. 


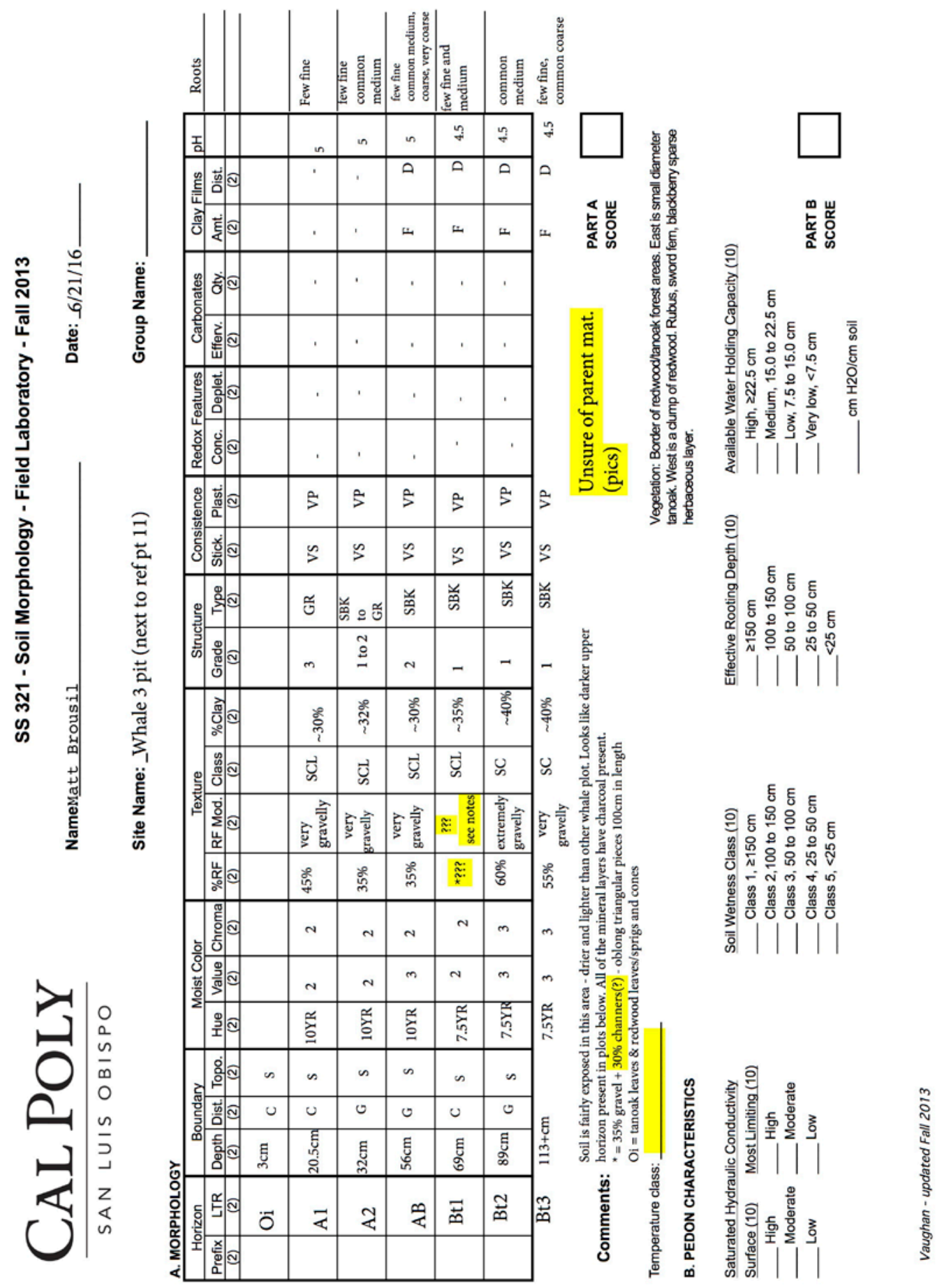

Figure A.17. Front of soil pit classification sheet for Whale Point \# 3. 


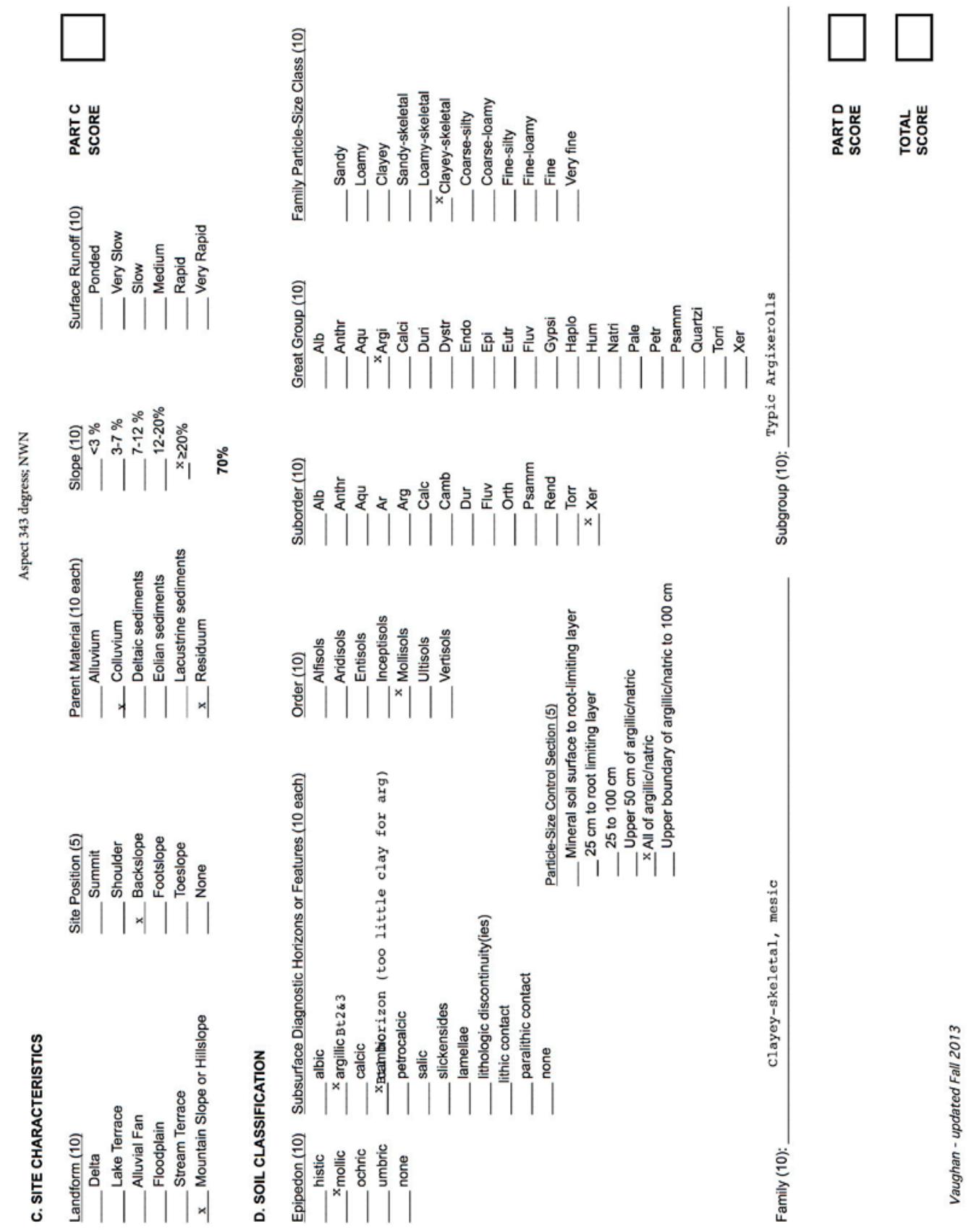

Figure A.18. Back of soil pit classification sheet for Whale Point \# 3. 


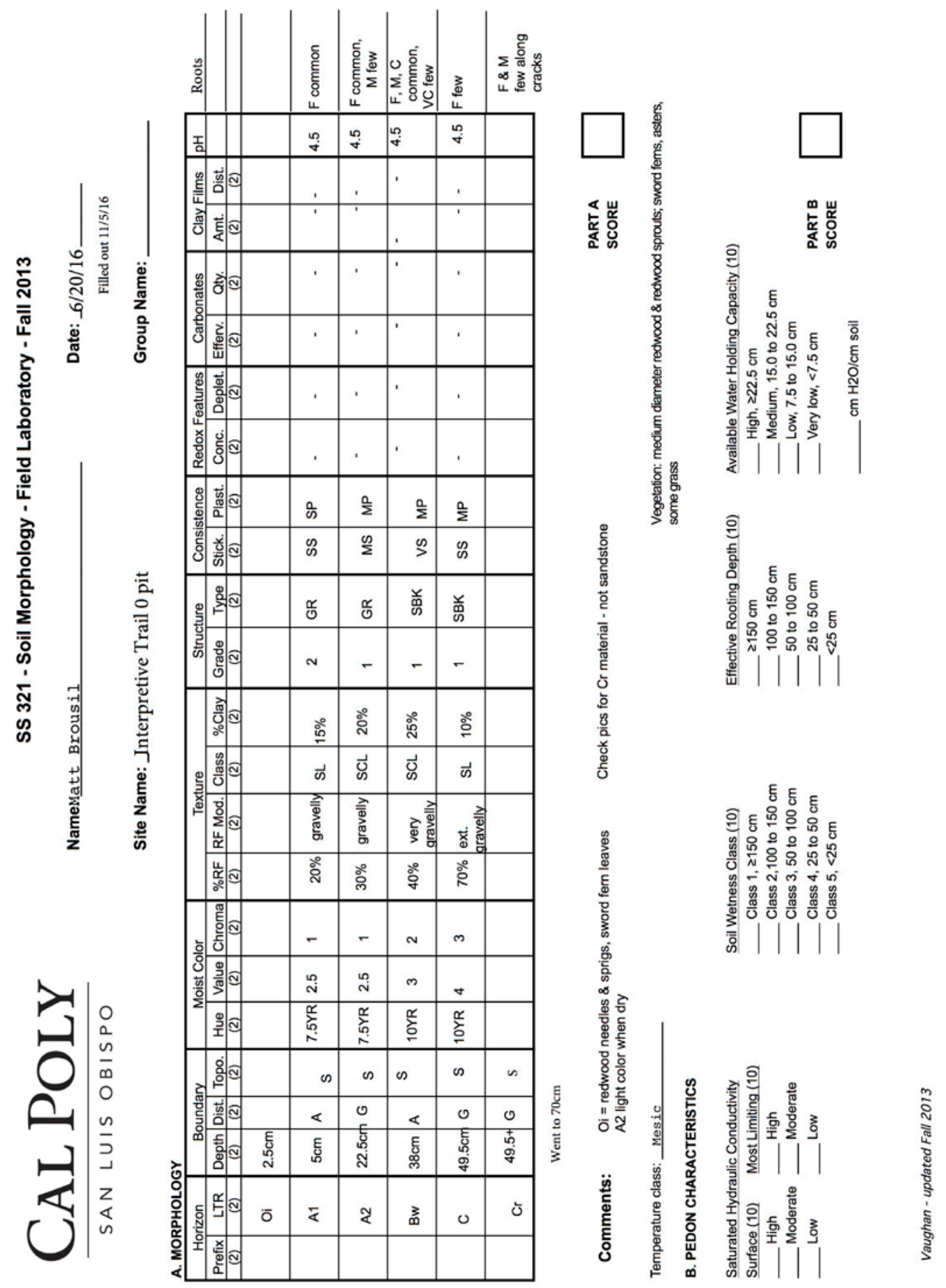

Figure A.19. Front of soil pit classification sheet for Interpretive Trail \# 0. 


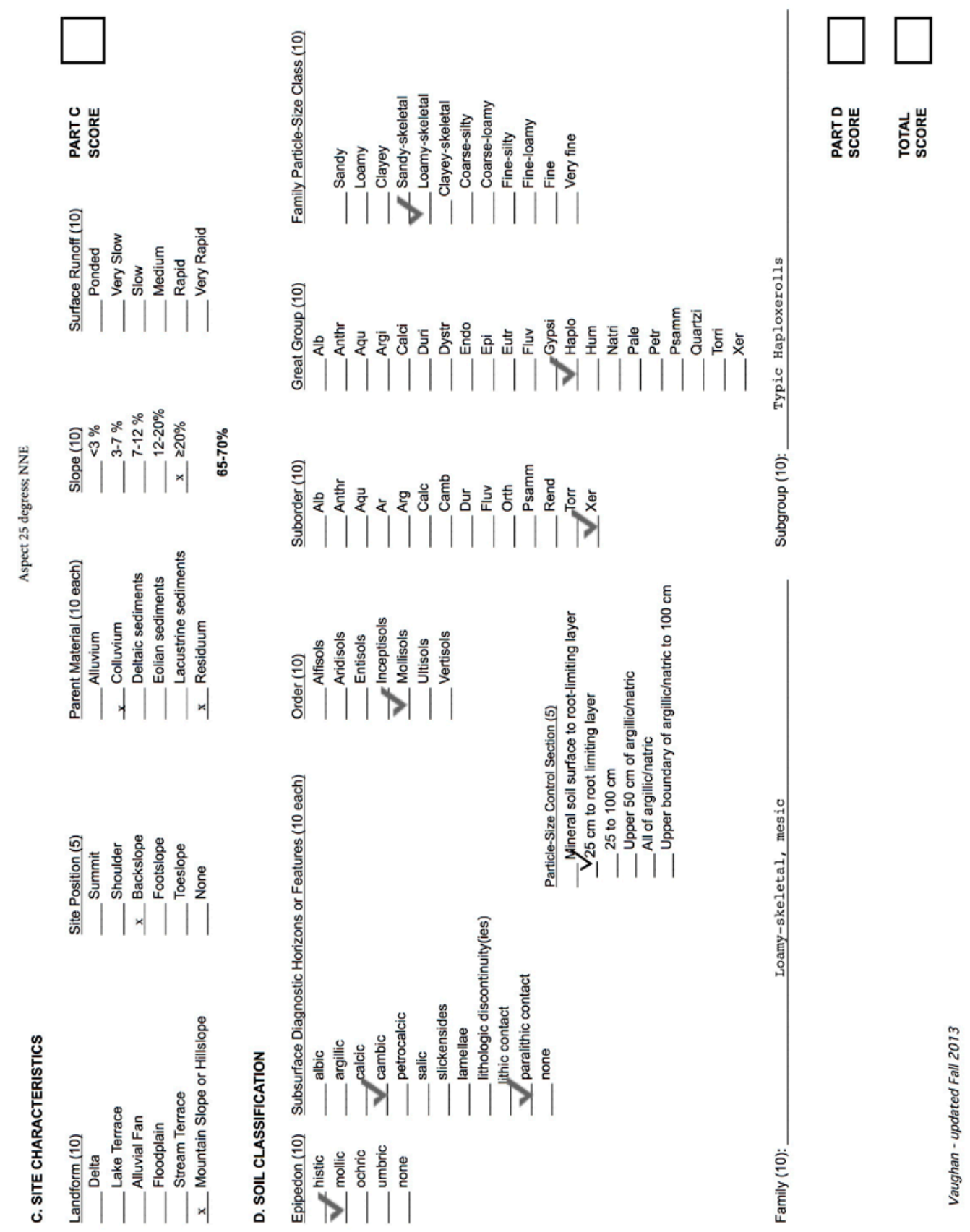

Figure A.20. Back of soil pit classification sheet for Interpretive Trail \# 0. 

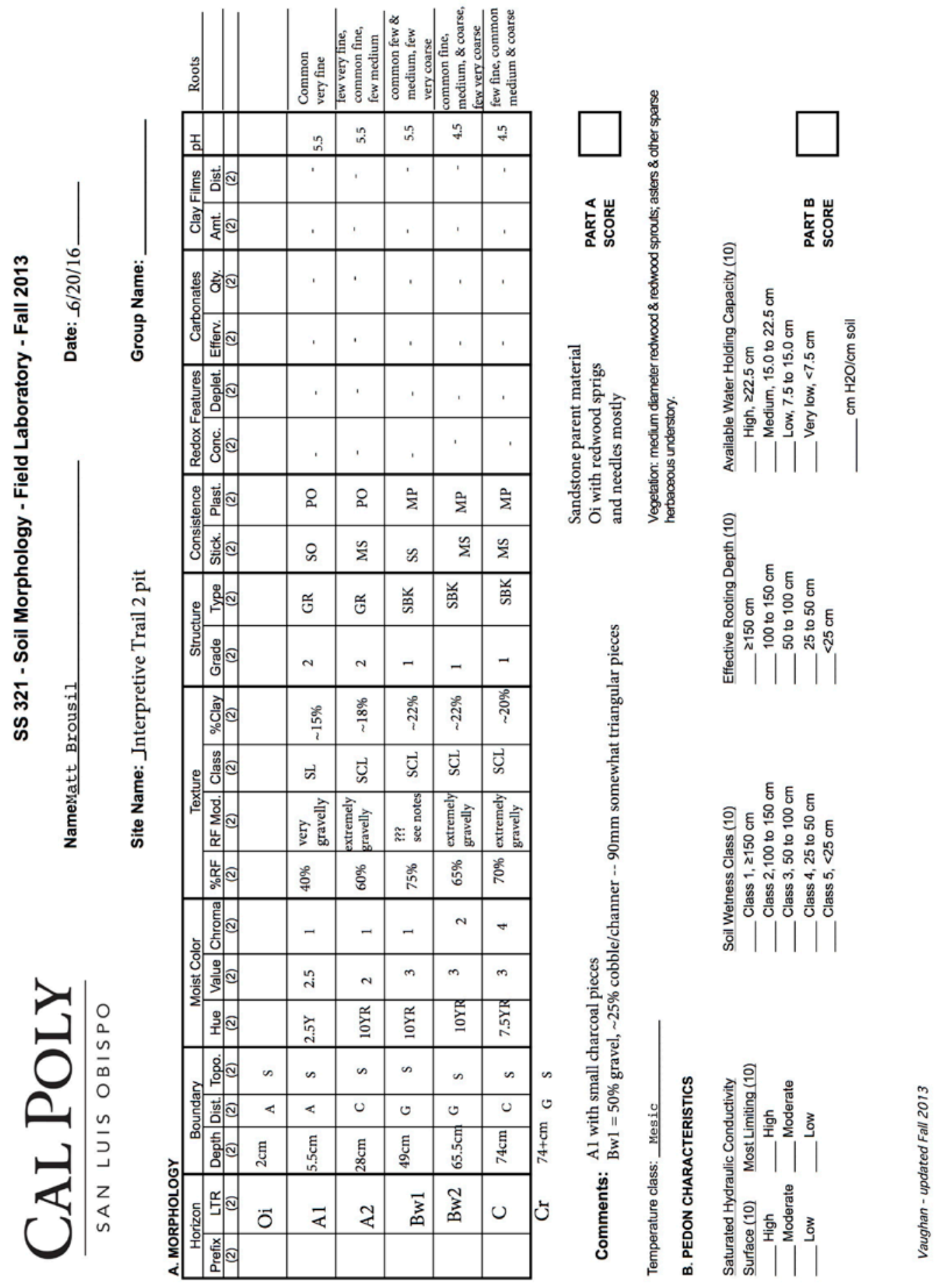

Figure A.21. Front of soil pit classification sheet for Interpretive Trail \# 2. 


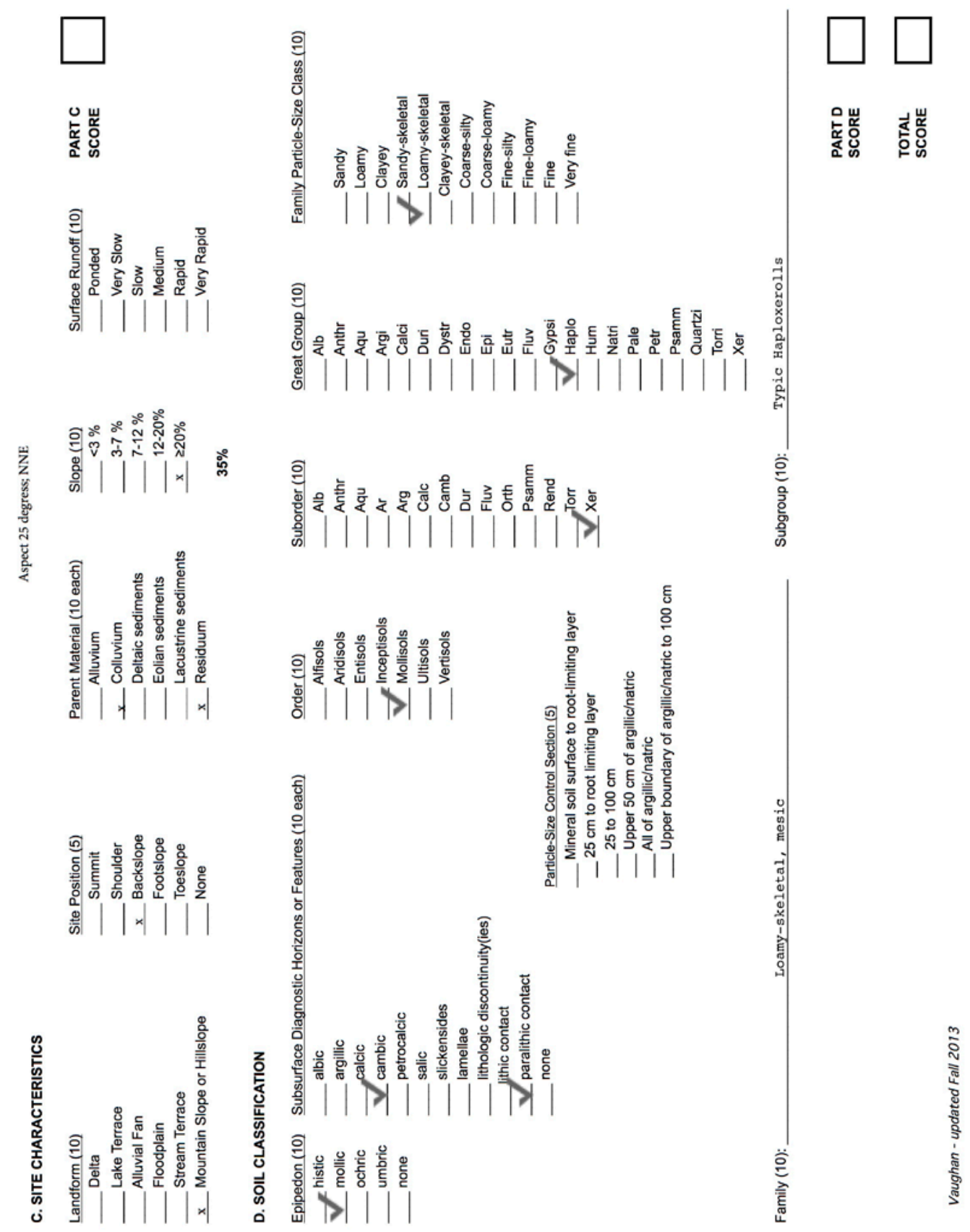

Figure A.22. Back of soil pit classification sheet for Interpretive Trail \# 2. 


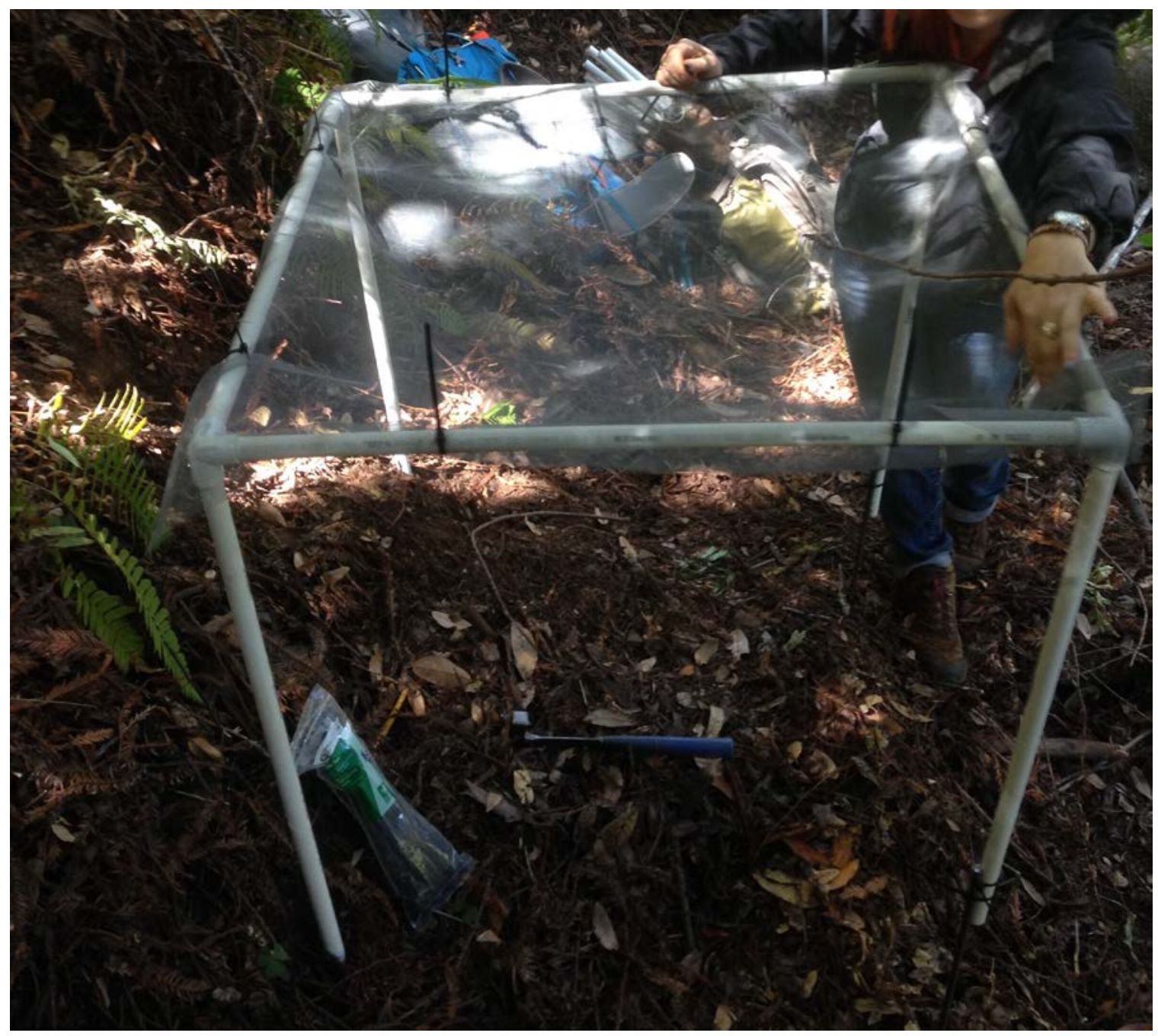

Figure A.23. A constructed seed rain trap. A PVC square was first constructed for the top of the trap, then the legs were attached, then the square of window screen ziptied on with some extra allowed to hang down in order to catch seeds and cones as they fell. 

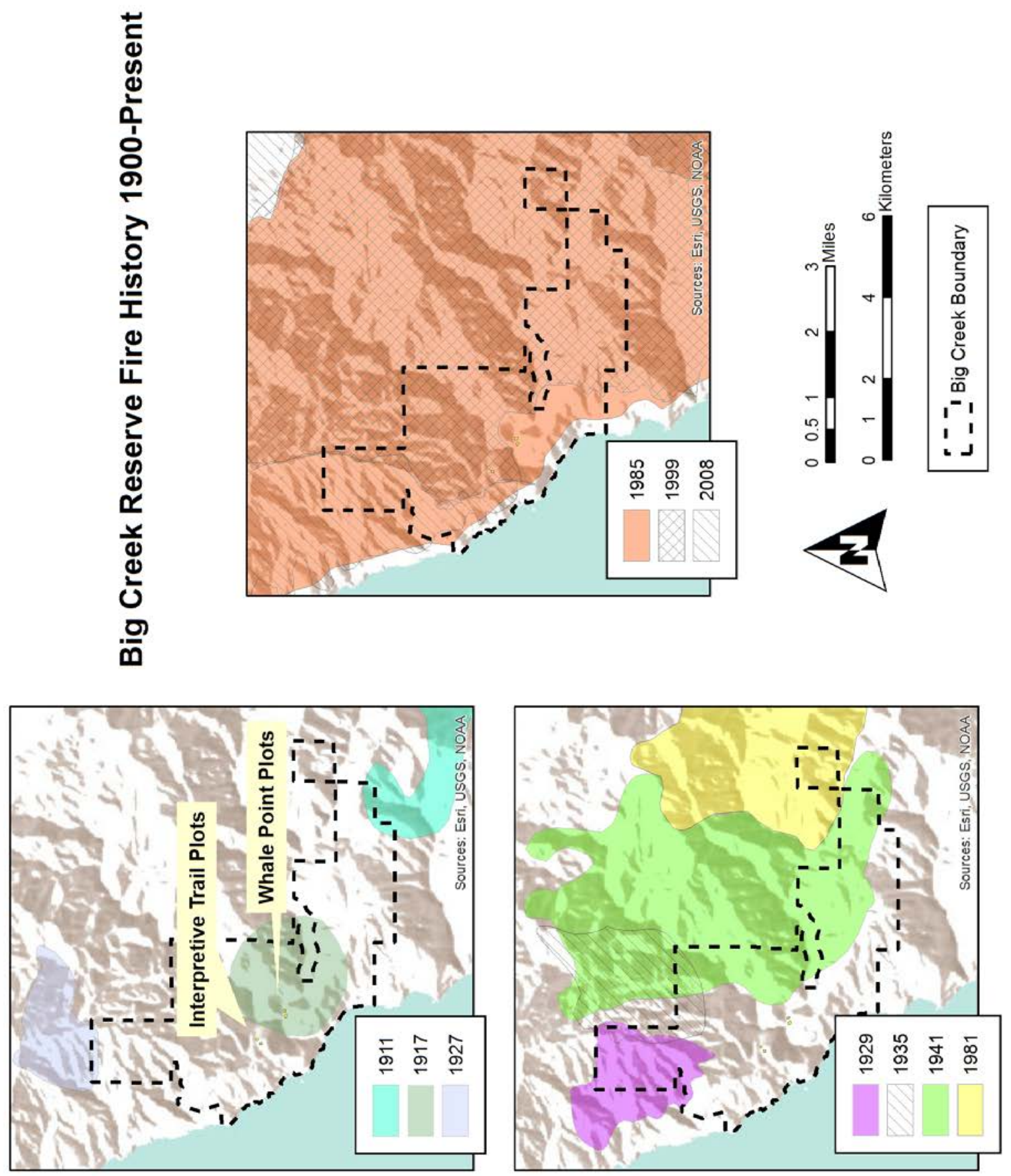

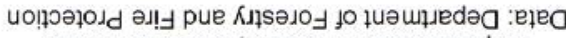

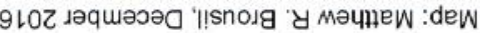

Figure A.24. Map of available fire history at the Big Creek Reserve properties. Data from Department of Forestry and Fire Protection (2015). 

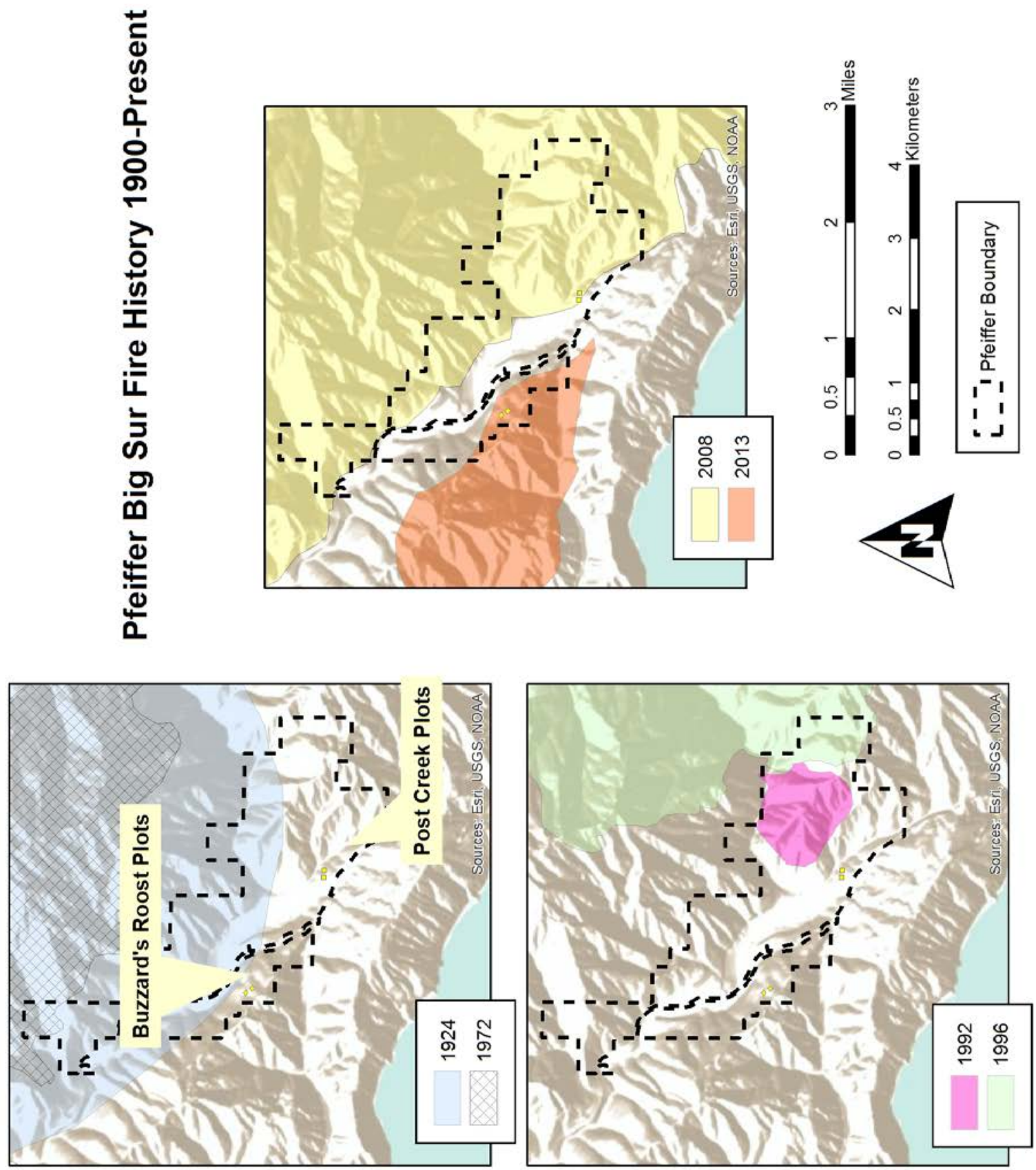

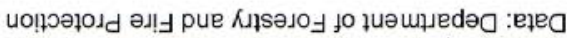

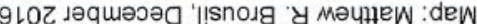

Figure A.25. Map of available fire history at Pfeiffer Big Sur State Park. Data from Department of Forestry and Fire Protection (2015). 